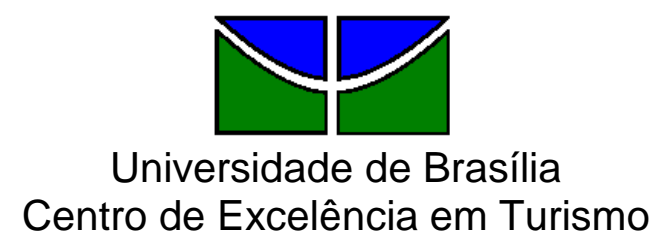

Pós-graduação Lato Sensu

Curso de Especialização em Gestão de Negócios em Turismo

\title{
AVALIAÇÃO DA VIABILIDADE DE UM EMPREENDIMENTO PARA COMERCIALIZAÇÃO DE PRODUTOS ÁRABES EM BRASÍLIA
}

Daiany Georges de Paula Ottoni

Brasília - 2009 


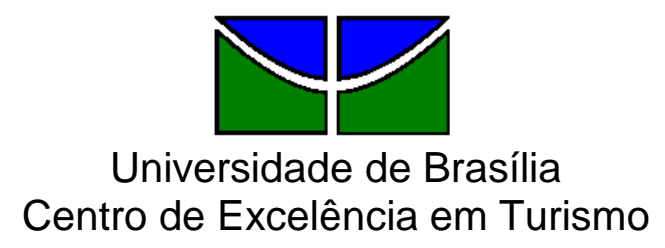

Pós-graduação Lato Sensu

Curso de Especialização em Gestão de Negócios em Turismo

\section{AVALIAÇÃO DA VIABILIDADE DE UM EMPREENDIMENTO PARA COMERCIALIZAÇÃO DE PRODUTOS ÁRABES EM BRASÍLIA}

Daiany Georges de Paula Ottoni

Professora Orientadora - Marina Figueiredo Moreira, Msc

Monografia apresentada ao Centro de Excelência em Turismo da Universidade de Brasília - CET/UnB, como requisito parcial à obtenção do grau de Especialista em Gestão de Negócios em Turismo. 
Ottoni, Daiany Georges de Paula

Avaliação da viabilidade de um empreendimento para comercialização de produtos árabes em Brasília / Daiany

Ottoni Georges de Paula. - Brasília, 2009.

92 f. : il.

Monografia (especialização) - Universidade de Brasília, Centro de Excelência em Turismo, 2009.

Orientadora: Marina Figueiredo Moreira.

1. Plano de negócios. 2. Empreendedorismo. 3. Turismo Gastronômico. 
Universidade de Brasília

Centro de Excelência em Turismo

Pós-graduação Lato Sensu

Curso de Especialização em Gestão de Negócios em Turismo

\section{AVALIAÇÃO DA VIABILIDADE DE UM EMPREENDIMENTO PARA COMERCIALIZAÇÃO DE PRODUTOS ÁRABES EM BRASÍLIA}

Daiany Georges de Paula Ottoni

Aprovado por:

Professora Mestre - Marina Figueiredo Moreira

Professor Mestre - Domingos Sávio Spezia

Professora Mestre - Cristina Castro Lucas de Souza

Brasília, 13 de julho de 2009. 
Dedico esse trabalho ao meu marido, Marcelo Ottoni e minha mãe, Nasra Hanna, pelo apoio aos meus estudos e por serem as pessoas mais importantes de minha vida. 
Primeiramente gostaria de agradecer a Deus.

Segundo gostaria de agradecer ao meu marido, minha mãe e amigos que me deram todo o apoio necessário para o desenvolvimento desse projeto.

Agradeço também a professora Marina por ter acreditado em mim e no meu trabalho. 
"Na administração o amor de fato, quase nunca vem no ato, é sempre parte do aproveitamento do prato, que quando guardado, deve ser reinventado na espera de um fazer gostar para a surpresa de quem chegar no dia seguinte" (Sérgio Dal Sasso). 


\section{RESUMO}

Para abertura de um negócio, recomenda-se a realização de um plano de negócios. Com essa ferramenta, o empresário sistematiza suas idéias e planeja de forma mais eficiente antes de entrar no mercado. Este trabalho adota como objetivo geral desenvolver um estudo para averiguação da viabilidade de implantação de um empreendimento que fornece produtos árabes em Brasília a partir da elaboração de um plano de negócios. Já os objetivos específicos são: conhecer a organização e os processos de um empreendimento que oferece produtos árabes, analisar o mercado consumidor, fornecedores e concorrentes; desenvolver o plano de negócios; e avaliar a viabilidade econômica de implantação do negócio proposto. Por se tratar de um empreendimento que atuará no ramo alimentício e que terá pretensão de atuar no Festival de Gastronomia Brasil Sabor Brasília, cria-se a necessidade de investigar assuntos relacionados ao turismo, uma vez que os turistas se deslocam para Brasília com o intuito de prestigiar o festival, hospedando-se em hotéis e usufruindo dos serviços de restaurante e comércio, movimentando, assim, a cadeia produtiva do turismo. A idéia do tema surgiu a partir da vontade de ter um negócio próprio e da oportunidade de haver um único empreendimento que vende produtos árabes em Brasília. Para a construção do plano de negócios foi realizada uma pesquisa exploratória para obtenção de conhecimentos teóricos e práticos, uma pesquisa bibliográfica, para construção da revisão de literatura e coleta de dados secundários, e pesquisa de campo com aplicação de questionários aos potenciais clientes. A elaboração do plano de negócios não foi utilizada somente como um instrumento de planejamento, através dos resultados obtidos ocorreu uma interação com o mercado consumidor percebendo a aceitação do produto e o baixo nível do concorrente. Através da pesquisa de campo foi possível perceber que a maioria dos entrevistados não sabia o que era empório ocorrendo assim à mudança do nome do estabelecimento de empório árabe para CANTINHO ÁRABE. Conclui-se através do plano de negócios que a implantação de um empreendimento com produtos árabes em Brasília é viável, sendo que é possível verificar o ponto de equilíbrio do empreendimento a partir do oitavo mês e o prazo de retorno dos recursos a partir do primeiro mês do segundo ano.
1. Turismo Gastronômico
2. Empreendedorismo
3. Plano de negócios 


\begin{abstract}
To open a business is necessary make a business plan. With this tool, the venturer can organize your ideas making a more efficient plan. The objective of this work is develop a study to check the feasibility of a joint venture deployment that provides Arabian products in Brasilia based in a business plan. Know the process organizations of an Arabic store, analyze the consumer market, vendor, competitors, developing the business plan and assess the feasibility economic are the specifics objectives. As a joint venture that will act in class and which will claim to serve on the Brazilian taste Food Festival Brasília, creates the need to investigate tourism-related issues, since tourists travel to Brasilia with the intention of honoring the Festival, staying in hotels and restaurant services enjoys and trade, surf the productive chain of tourism. The idea of the issue arose from the desire for a own business and the opportunity to haven't an other Arabic store in Brasilia. For the construction of the business plan we did an exploratory search to get theoretical and practical knowledge, a bibliographic search for construction of the review of literature and data collection, and secondary search field with the application of questionnaires with potential customers. The business plan was not used only as a tool for planning, through the results obtained an interaction with the consumer market realizing the acceptance of the product and the low level of competitor. Through the search field could realize that most interviewed didn't know what Emporium means, with that we changed the name of the establishment of Arabic Emporium to CANTINHO ARABE. It is concluded through the business plan that the establishment of a joint venture with Arabic products in Brasilia is viable the balance point of equilibrium was found at the eighth month and period of return of resources at the first month of the second year, of work.
\end{abstract}

Keywords:
1. Gastronomic tourism
2. Entrepreneurship
3. Business plan 


\section{SUMÁRIO}

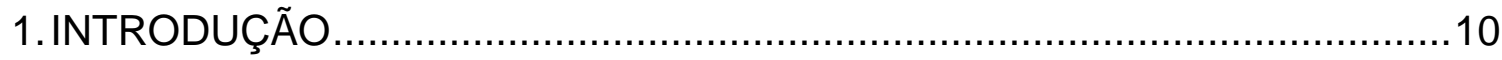

1.1. Apresentação e delimitação do tema ...................................................10

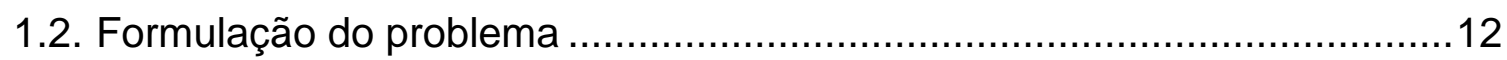

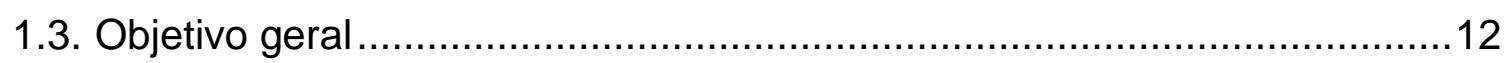

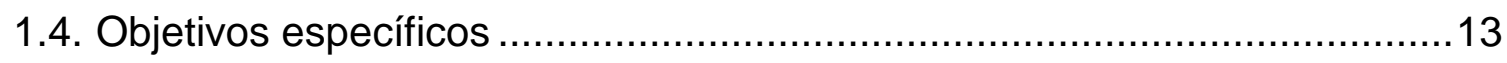

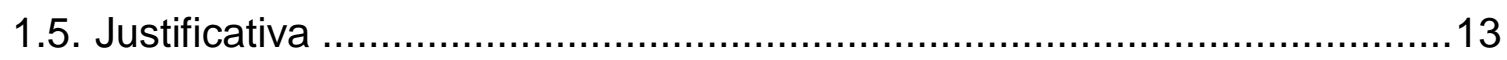

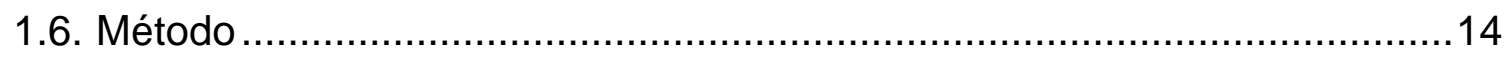

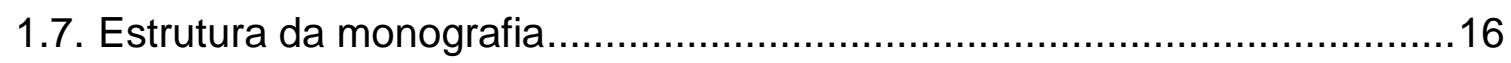

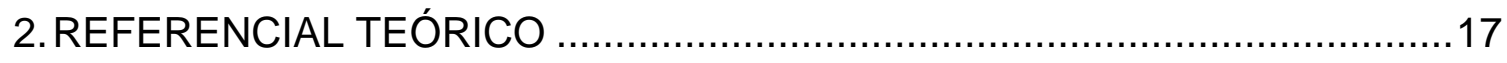

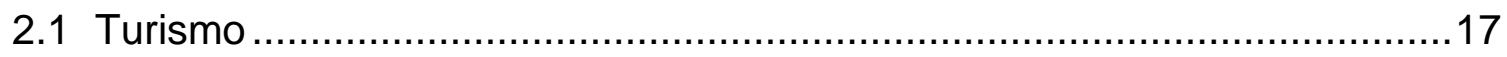

2.2 Turismo cultural........................................................................ 19

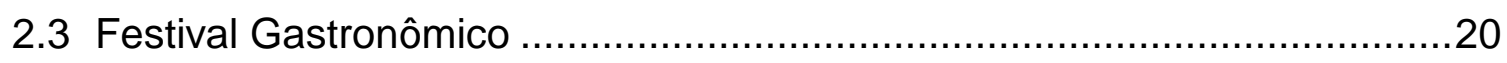

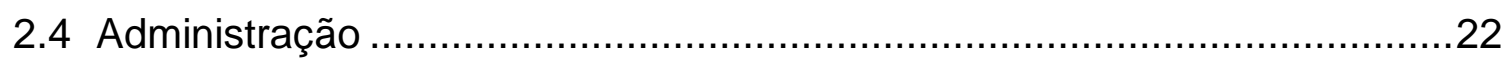

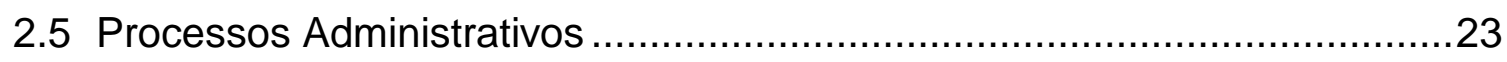

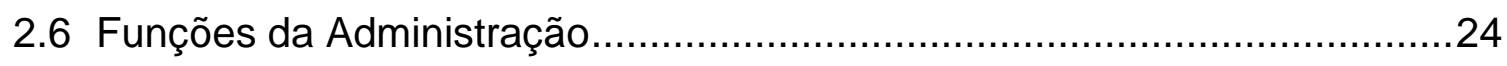

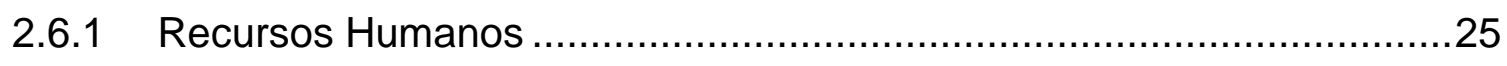

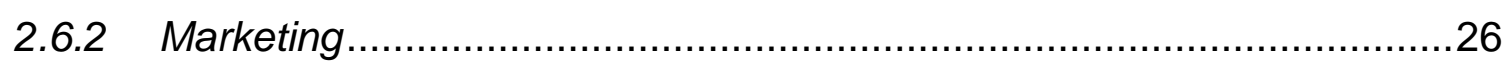

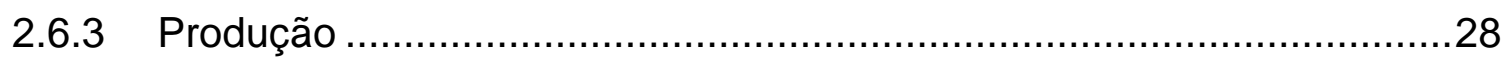

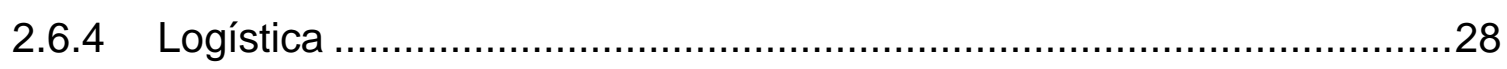

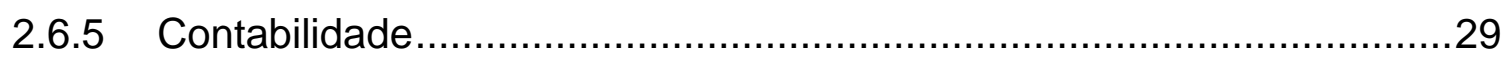

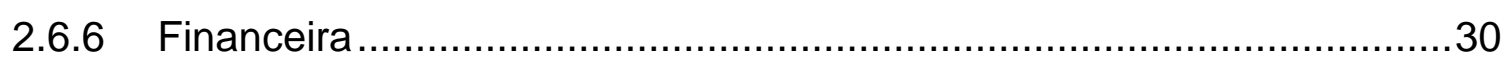

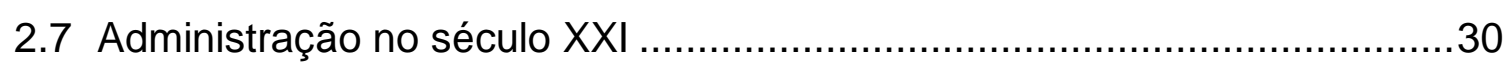

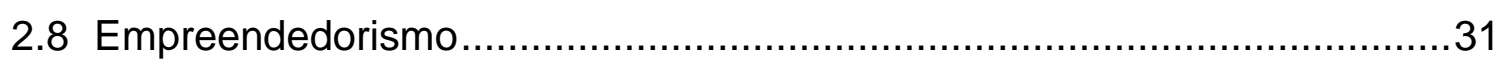

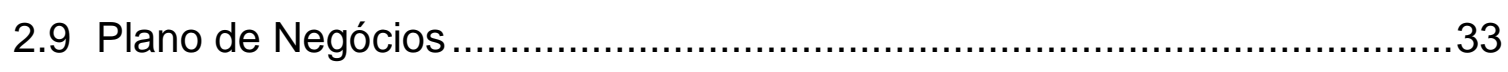

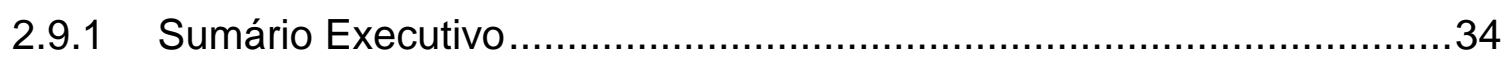

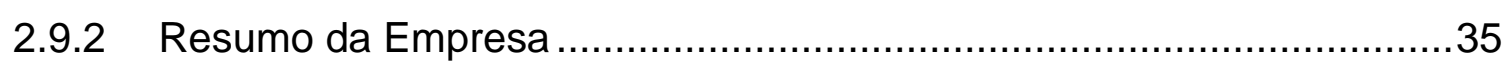

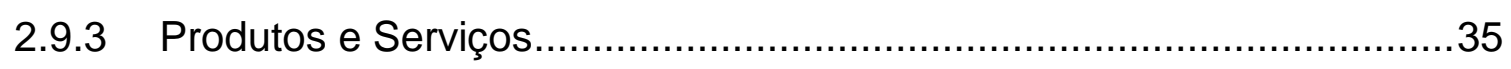

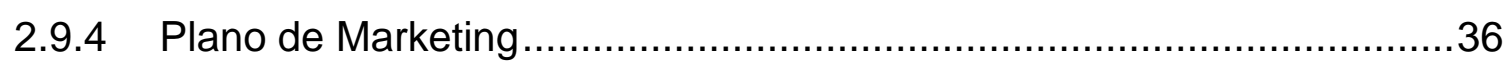

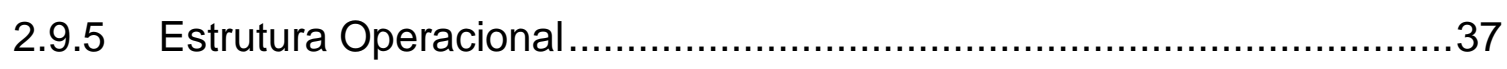




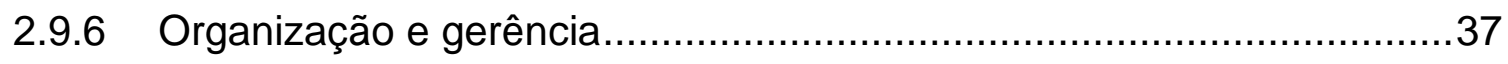

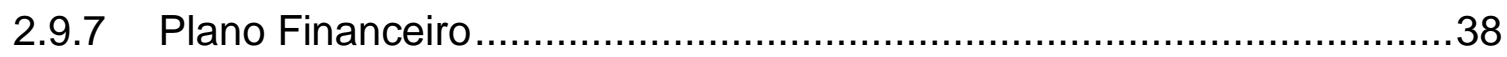

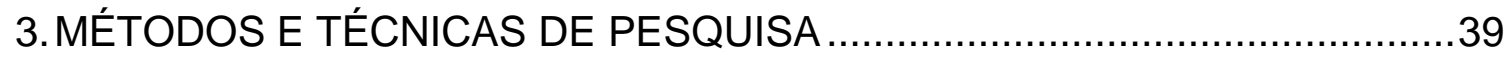

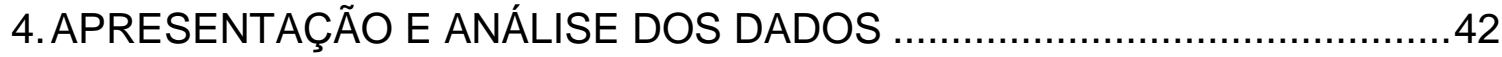

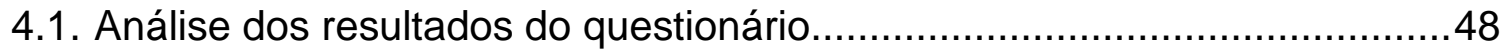

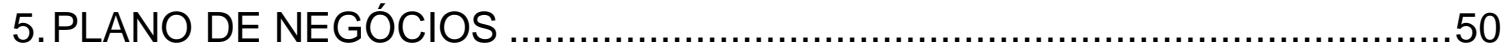

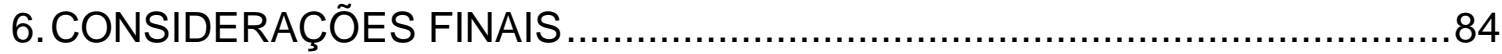

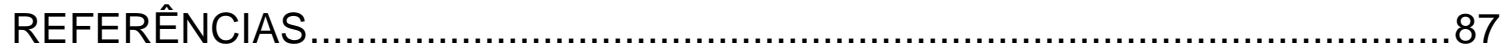

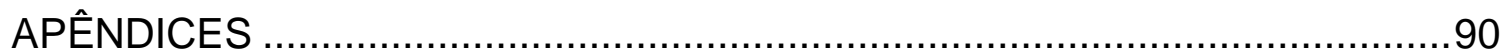

Apêndice A: Questionário aplicado aos potenciais clientes. .............................90

Apêndice B: Roteiro de Entrevista aplicado ao dono de um empório árabe. .....92 


\section{INTRODUÇÃO}

\subsection{Apresentação e delimitação do tema}

Segundo Lopes (2009), a gastronomia, quando associada ao turismo, tornase um importante atrativo capaz de promover o contato com a diferença e estimular o interesse pelos destinos, abrindo novas perspectivas para a exploração turística e para a criação de novos empreendimentos, pois dá acesso a novas experiências aos viajantes e, ainda, deixa livre o caminho de oportunidades para que regiões e cidades mostrem seus atrativos a partir de novas perspectivas. O turismo, como experiência, deve proporcionar uma percepção positiva e atender aos desejos dos viajantes durante seus momentos de lazer e entretenimento

A cidade de Brasília tem apresentado, nos últimos anos, perspectivas de crescimento para as atividades ligadas ao turismo. Além de ser um exemplo da arquitetura moderna para todo o mundo, Brasília é hoje considerada Patrimônio Histórico da Humanidade. Por se tratar de uma cidade nova, possui grande diversidade cultural, resultando da mistura de todas as regiões em um único local e, por não ter uma identidade cultural formada, está aberta para novas experiências culturais (TV Turismo, 2002).

Conforme Cavalcante (2009), a partir dessa abertura cultural, surgiu, há seis anos, o festival de gastronomia Brasil Sabor Brasília, no qual acontece um conjunto de ações estratégicas com resultados muito positivos que buscam a promoção e a valorização da gastronomia na cidade, atraindo visitantes e se aproximando das atividades turísticas. Esses festivais são valorizados porque estão diretamente ligados ao prazer e à sensação de saciedade adquiridos através da comida e da viagem, favorecendo o desenvolvimento das empresas ligadas ao ramo da alimentação, em todos os setores, gerando novos empregos, melhorando a qualidade de vida nas cidades.

Com o favorecimento a empreendimentos que trabalham o turismo gastronômico, surgem oportunidades para negócios que atuam na área da 
gastronomia, culminando com a proposição de implantação de um empreendimento que forneça produtos árabes ao público brasiliense. Tendo por objetivo avaliar a real viabilidade de implantação de um negócio com as características descritas no contexto do turismo gastronômico em Brasília, propõe-se a realização de um estudo que considere o comercio varejista em Brasília e suas perspectivas para a implantação de um novo negócio na área de alimentos, bebidas e fumo. .

Segundo estudo realizado pelo SEBRAE (2005), o comércio varejista pode ser segregado em dois grandes grupos. O primeiro corresponde ao segmento de hiper e supermercados, maior fonte de receita do varejo (venda direta ao consumidor), com $40,7 \%$ da receita varejista e $13,3 \%$ da receita total do comércio no ano de 2005. O segundo é formado por todo o comércio especializado. O varejo apresenta duas formas básicas de organização de loja. A primeira é o auto-serviço, tipo predominante dos hiper e supermercados, onde não há contato pessoal entre consumidores e vendedor. A outra forma é a loja de balcão, em que há maior grau de interação entre as partes e a qualidade do serviço de atendimento se torna ainda mais importante. Este é o formato principal do comércio especializado.

Segundo dados do IBGE (Instituto Brasileiro de Geografia e Estatística), as vendas do comércio varejista brasileiro cresceram 1,5\% em fevereiro na comparação com janeiro de 2009. Em relação a fevereiro de 2008 , houve alta de $3,8 \%$. No acumulado do primeiro trimestre, o comércio registrou crescimento de 4,9\%, na comparação com o mesmo período do ano passado.

Considerando as perspectivas de sucesso para novos negócios no comércio em Brasília, este trabalho propõe-se a investigar a viabilidade de implantação de um comércio especializado em produtos árabes na cidade. Conforme indicado na distribuição de setores do comércio do SEBRAE (2005), o Cantinho árabe seria classificado como varejo especializado em alimento, bebida e fumo no formato de loja balcão. Busca-se, nesse trabalho, avaliar a viabilidade de implantação do empreendimento proposto considerando o embasamento teórico necessário para o exercício da função empreendedora. 


\subsection{Formulação do problema}

A gastronomia integra ciências favoráveis ao ser humano. Podemos descobrir histórias de civilizações, ritos, modas e modos em qualquer prato, constituindo, na forma de alimentação, uma cidade, uma região ou um país. O ser humano se alimenta de acordo com a sociedade da qual que faz parte. Cada cultura possui diferentes alimentos e modos de preparo. O turismo gastronômico está, assim, diretamente ligado ao prazer e à sensação de saciedade adquiridos através da comida e da viagem. Algumas regiões se aproveitam de sua cultura, história e tradições, e as divulgam através da gastronomia, lançando um produto turístico distinto.

O turismo gastronômico favorece, então, o desenvolvimento das empresas ligadas ao ramo da alimentação em todos os setores, gerando novos empregos e melhorando a qualidade de vida nas cidades. O turismo gastronômico é parte integrante do turismo cultural e possui enorme importância por ser autônomo e produzir significativa margem de lucro.

Destarte, este trabalho tem como objetivo verificar a viabilidade da implantação de um empreendimento que comercializa produtos árabes em Brasília com a finalidade de explorar um produto turístico distinto, executar o plano de criação do mesmo e constatar o interesse do mercado nesse novo segmento. Tendo por base as premissas apresentadas, formula-se a seguinte questão de pesquisa: "a abertura de um empreendimento que fornece produtos árabes em Brasília é viável”?

\subsection{Objetivo geral}

Tem-se como objetivo geral: desenvolver um estudo para verificação da viabilidade de implantação de um empreendimento voltado ao turismo gastronômico para comercializar produtos árabes em Brasília a partir da elaboração de um plano de negócios. 


\subsection{Objetivos específicos}

$\checkmark \quad$ Identificar a organização e os processos de um empreendimento que comercializa produtos árabes;

$\checkmark \quad$ Analisar o mercado consumidor, fornecedores e concorrentes no contexto do turismo gastronômico;

$\checkmark \quad$ Desenvolver o plano de negócios;

$\checkmark \quad$ Avaliar a viabilidade econômica de implantação do empreendimento proposto.

\subsection{Justificativa}

Segundo Ciaffone (2003), a gastronomia associada ao turismo é um importante atrativo. Promove o contato com a diferença e estimula o interesse pelos destinos, abrindo novas perspectivas para a exploração turística e criação de novos empreendimentos, pois dá acesso a novas experiências aos viajantes e deixa livre o caminho de oportunidades para que regiões e cidades mostrem seus atrativos a partir de novas perspectivas. O turismo como experiência deve proporcionar uma percepção positiva e atender os desejos dos viajantes durante seus momentos de lazer e entretenimento. Diante disso, em função da maior facilidade de deslocamento proporcionada pelo fenômeno da globalização, a comida atraiu a atenção e fomentou o aparecimento da valorização local fazendo com que o turismo se beneficiasse especialmente nos países que perceberam e souberam explorar essa relação profícua, proporcionando novas percepções para o étnico, o regional e os produtos locais.

Ao perceber essa oportunidade voltada ao turismo e gastronomia, surgiu o interesse de abrir um negócio que comercialize produtos árabes, para que nesse empreendimento os turistas possam ter contato com outra cultura. A escolha de comercializar produtos árabes aconteceu após uma análise das grandes 
contribuições no campo cultural, artístico e literário que povo árabe disseminou pelo mundo.

Após a decisão de qual empreendimento montar e quais produtos oferecer, surgiu à necessidade de avaliar a real situação do mercado neste segmento, o perfil do público-alvo e também o estudo da viabilidade, para que seja alcançado o retorno desejado na implantação e no funcionamento do negócio. O presente trabalho busca informações que possam contribuir para uma boa gestão da empresa, visto que é preciso ter conhecimento de todas as funções administrativas antes do início das atividades.

Para que o tema seja abordado de forma clara, é necessário que seja feito um estudo sobre os fundamentos da Administração no que se refere à gestão empresarial, para que, em seguida, seja feito um estudo do mercado consumidor e do mercado concorrente a fim de desenvolver um bom plano de negócios que vá subsidiar futuramente a implantação segura do negócio proposto.

Por se tratar de um comércio no ramo alimentício, ele também tem grande relevância para o turismo, porque as pessoas que vêm de outras cidades terão a oportunidade de apreciar os produtos do oriente médio. A empresa tem como intuito, ainda, participar do Festival de Gastronomia Brasil Sabor Brasília, para o quais várias pessoas vêm de outras cidades para conhecer e degustar os pratos que o comércio da região oferece. Torna-se necessário, portanto, realizar um estudo sobre o Turismo, Turismo Cultural e Festival Gastronômico em Brasília.

\subsection{Método}

Esse trabalho foi desenvolvido no período de abril a junho de 2009, com o intuito de obter embasamento teórico e prático para criação de um plano de negócios de um empreendimento que fornece produtos árabes para que posteriormente seja viável a abertura da empresa de forma planejada. Assim, foi preciso um período integral para execução do trabalho de forma eficiente e eficaz.

Para alcançar os objetivos específicos - identificar a organização e processos de um empreendimento que fornece produtos árabes; analisar o mercado 
consumidor, fornecedor e concorrentes no contexto do turismo gastronômico e desenvolver o plano de negócios - foram adotados os seguintes procedimentos:

$\checkmark$ Pesquisa bibliográfica: construção da revisão de literatura e coleta de dados secundários sobre os temas: Turismo, Turismo Cultural, Festival Gastronômico, Administração, Processos Administrativos, Recursos Humanos, Marketing, Produção, Logística, Contabilidade, Financeira, Administração do século XXI, Empreendedorismo, Plano de Negócios, Sumário Executivo, Resumo da empresa, Produtos e Serviços, Plano de Marketing, Estrutura Operacional, Organização e Gerência e Plano Financeiro.

$\checkmark$ Pesquisa documental: utilização de documentos para obtenção de dados secundários-: dados estatísticos do IBGE e SEBRAE.

$\checkmark$ Pesquisa participante: participação do pesquisador como cliente das empresas na mesma área de atuação do empreendimento proposto, com o objetivo de compreender aspectos da dinâmica de funcionamento das organizações.

$\checkmark$ Pesquisa interativa: contato com possíveis fornecedores e levantamento de dados através da internet (preço dos produtos e melhores produtos a serem fornecidos aos clientes).

$\checkmark$ Pesquisa de mercado: foi feito um estudo exploratório, através de um roteiro de entrevista aplicado de forma indireta ao proprietário de um empreendimento que fornece produtos árabes o qual não sabia que estava sendo entrevistado, porém o mesmo respondeu as perguntas propostas, permitindo dessa forma um conhecimento amplo sobre o comércio varejista em Brasília (produto, preço, praça, promoção).

$\checkmark$ Coleta de dados: aplicação de questionários a potenciais clientes, moradores da Asa Sul Brasília- DF, sendo possível identificar condições de mercado relativas ao negócio proposto;

$\checkmark$ Após a aplicação dos questionários foi realizada uma análise dos dados de forma estatística e apresentado os resultados alcançados através de gráficos.

$\checkmark$ Elaboração de um plano de negócios considerando as informações obtidas no referencial teórico e na análise de dados para verificar a viabilidade de implantação de do empreendimento proposto. 
O universo da pesquisa foi à população de Brasília. A amostragem da pesquisa foi não-probabilística (por julgamento), a amostra obtida para o estudo foi de 50 respondentes, o número definido traz representatividade para a pesquisa considerando o prazo.

A coleta foi realizada no período entre 27 de abril a 08 de maio de 2009, foram coletados dados com cidadões de Brasília. Em relação aos dados coletados a partir dos questionários aplicados aos potenciais clientes, foram analisados estatisticamente e apresentados em gráficos com o intuito de identificar as necessidades, desejos e carências existentes no mercado e também foram analisados de forma qualitativa no que diz respeito ao conteúdo para elaboração do plano de negócios, sendo assim uma pesquisa qualitativa e quantitativa.

\subsection{Estrutura da monografia}

O trabalho é estruturado em seis capítulos. No primeiro capítulo é apresentado ao leitor o tema do trabalho, seus objetivos, métodos e técnicas utilizados para alcançá-los e, ainda, a justificativa do tema.

No capítulo dois, tem início à apresentação da revisão de literatura relacionada a turismo, turismo cultural, festival gastronômico e temas vinculados a administração, empreendedorismo e plano de negócios. No capítulo três, surge a apresentação dos métodos utilizados para coleta e análise de dados. No capítulo quatro, o leitor verifica os resultados encontrados. No capitulo cinco e apresentado o plano de negócios, No capitulo seis são apresentadas as conclusões. 


\section{REFERENCIAL TEÓRICO}

\section{$2.1 \quad$ Turismo}

Segundo Ignarra (2002), o fenômeno turístico está relacionado com visitas a um local diverso de residência das pessoas e viagens. Então, se pode afirmar que o turismo se iniciou a partir do momento em que o homem deixou de ser sedentário e passou a viajar. Um dos principais motivos que os incentivavam era a necessidade de comércio com outros povos.

Percebe-se que o turismo existe desde nossos primórdios, pois o ato de se deslocar de uma cidade para outra, independente do motivo que o leva, é considerado um fenômeno turístico.

A Organização Mundial do Turismo define turismo como "o deslocamento para fora do local de residência por período superior a 24 horas e inferior a 60 dias motivados por razões não-econômicas" OMT (apud IGNARRA, 2002, p.23)

Para Trigo (1995, p. 10),

Pode-se dizer, em resumo, que qualquer viagem temporária com duração superior a vinte quatro horas é turismo e que as viagens de apenas um dia são excursões. Em geral, não se classificam como turismo viagens de estudo ou trabalho (caso das migrações ou viagens profissionais de longa duração, como as empreendidas por estudantes, diplomatas, militares, técnicos, religiosos, etc.).

Para Beni (2002, p.35),

Turistas são visitantes temporários que permaneçam pelo menos vinte e quatro horas no país visitado, cuja finalidade de viagem pode ser classificada sob um dos seguintes tópicos: lazer (recreação, férias, saúde, estudo, religião e esporte), negócios, família, missões e conferências, e excursionistas são visitantes temporários que permaneçam menos de vinte e quatro horas no país visitado. 
Outras definições foram surgindo e criando características para o turismo, como é o caso de que o turista precisa permanecer um período maior do que vinte quatro horas no seu local de destino, pois do contrário são considerados excursionistas.

Lage e Milone (2000) nos mostram que os conceitos que afirmam que turismo corresponde a viagens para regiões distantes de mais de 50 milhas dos locais de residência dos turistas; ou, que tenham a permanência dos viajantes por mais de 24 horas no lugar visitado; ou, ainda, que não possam exercer uma ocupação remunerada nos dias de hoje, são considerados conceitos ultrapassados.

O turismo, para Cooper (2001, p.40), "pode ser pensado como sendo uma ampla gama de indivíduos, empresas, organizações e lugares, que se combinam de alguma forma para proporcionar uma experiência de viagem".

De acordo com Lage e Milone (2000), é impossível limitar uma definição específica para o turismo, pois é uma atividade socioeconômica, que gera a produção de bens e serviços visando à satisfação de diversas necessidades básicas e secundárias, além de se tratar de uma manifestação voluntária decorrente do deslocamento humano temporário, sendo indispensáveis os componentes fundamentais como transporte, alojamento, alimentação e, dependendo da motivação, o entretenimento.

Para que o turismo ocorra, é preciso primeiramente planejar e promover a viagem do turista. Além disso, é necessário satisfazer a todas as necessidades do turista com os vários serviços oferecidos durante essa viagem, por isso torna-se difícil definir turismo em um único parágrafo.

Fica claro que o turismo é um fenômeno complexo e que são vários os motivos que levam um turista a se deslocar de sua residência. Para tanto, continuando com a discussão acerca do turismo, seguirão nos próximos tópicos as definições de Turismo cultural e Festival Gastronômico, assuntos relacionados ao tema. 


\title{
$2.2 \quad$ Turismo cultural
}

Segundo Ignarra (2002), o turismo, além de englobar os aspectos das viagens na qual o turista conhece a vida e o pensamento da comunidade local, se apresenta com um fator importante para promover as relações culturais e a cooperação internacional. Por outro lado, estimula os fatores culturais dentro de uma localidade.

Vieira Pinto (apud TRIGO, 1995, p. 49) afirma que cultura é:

o processo pelo qual o homem acumula as experiências que vai sendo capaz de realizar discerne entre elas, fixa as de efeito favorável e, como resultado da ação exercida, converte em idéias as imagens e lembranças, a princípios colocados às realidades visíveis, e depois generalizados, desse contato com o mundo natural.

Conforme Barretto (2000, p. 19), Turismo Cultural é "todo turismo em que o principal atrativo não seja a natureza, mas algum aspecto da cultura humana". De acordo com a Organização Mundial do Turismo, "o turismo cultural seria caracterizado pela procura por estudos, culturas, artes cênicas, festivais, monumentos, sítios históricos, manifestações folclóricas ou peregrinações". OMT (apud BARRETTO, 2000, p.20).

Para Scatamacchia $(2005$, p.9),

\begin{abstract}
A preocupação da rotina em busca de prazer por meio de novos conhecimentos è uma atividade relativamente recente e serve de base para definir o turismo cultural. (...) O turismo cultural implica tanto a existências de espetáculos, exposições e outras manifestações, bem como de monumentos, museus e locais históricos. (...) Na verdade, o que impulsiona uma viagem cultural é a vontade de entrar em contato com diferentes hábitos e costumes, de conhecer outras culturas. $\mathrm{O}$ desejo de conhecer $\mathrm{O}$ exótico e o pitoresco tem sido objeto de atração e servido de fonte geradora de recursos econômicos para muitas regiões. (...) Atualmente o turismo cultural acha-se ameaçado no que se refere a alguns aspectos, pois a diversidade cultural, que é o seu grande atrativo, tende a diminuir em conseqüência do processo de homogeneização e globalização mundial.
\end{abstract}

O turismo cultural é caracterizado por dar importância à cultura humana. As pessoas que viajam em busca de cultura, além de dar importância para a vida da comunidade local que visitam, valorizam os seus aspectos culturais, como dança, 
comida, religião, arquitetura etc. Isso é explorado pelos eventos para atrair essas pessoas.

Brasília foi fundada em 1960. Por se tratar da capital de todos os brasileiros, é um exemplo da arquitetura moderna para todo o mundo. Brasília é hoje considerada Patrimônio Histórico da Humanidade. Tudo começou quando o então Presidente da República Juscelino Kubitschek resolveu mudar a Capital do país, Rio de Janeiro, para o Planalto Central. Ninguém poderia imaginar que num lugar deserto e distante pudesse nascer uma cidade futurista e tão bonita. Isso em tão pouco tempo.

Brasília, por ser uma cidade nova, possui grande diversidade cultural, é a mistura de todas as regiões em um único local. Por não ter uma identidade cultural formada, é uma cidade aberta para novas experiências culturais, como é o caso da aceitação do Festival de gastronomia Brasil Sabor Brasília, no qual é possível degustar pratos oferecidos nos empreendimentos da região, sendo assim uma grande oportunidade para o empreendimento CANTINHO ÁRABE disseminar a cultura do povo árabe para os turistas que se encontrarem na cidade em busca da variada gama gastronômica da cidade.

\subsection{Festival Gastronômico}

O desenvolvimento de assuntos relacionados ao festival gastronômico assume importância uma vez que os turistas se deslocam para Brasília com o intuito de prestigiar o Festival de gastronomia Brasil Sabor Brasília, usufruindo dos serviços de restaurante, comércio, hotéis, etc. Ocorre, assim, uma movimentação da cadeia produtiva do turismo, gerando renda e empregos na região no período do festival.

De acordo com Melo Neto (1999, p.202, 203, 204)

Os festivais são, na verdade, eventos que sedimentam tradições culturais e esportivas da região (...) Festivais são eventos que geram ocupação da cidade e permitem aos seus habitantes exercitarem a cidadania plena. (...) É um evento da cidade. Quando existe continuidade, o Festival incorpora-se ao calendário de eventos da Prefeitura e sua identidade incorpora-se ao ethos da cidade, tornando-se um dos principais elementos formadores de 
sua nova imagem. (...) A realização de festivais é uma estratégia promocional que tem demonstrado ser eficaz como forma de divulgação para qualquer cidade, região ou país.

Para Schüter (2003, p.69),

\begin{abstract}
A dimensão social e cultural da gastronomia determinou incorporá-la a complexo emaranhado das políticas de patrimônio cultural. $\mathrm{O}$ uso que 0 turismo faz do patrimônio determina que a gastronomia adquira cada vez mais importância para promover um destino e para captar correntes turísticas. E ainda para o autor a gastronomia como patrimônio local está sendo incorporada aos novos produtos turísticos orientados a determinados nichos de mercado, permitindo incorporar os atores da própria comunidade na elaboração desses produtos, assistindo ao desenvolvimento sustentável da atividade. (...) A gastronomia faz parte da nova demanda por parte dos turistas de elementos culturais. O desenvolvimento do turismo cultural é promovido devido à sua capacidade de gerar receita e empregos no lugar em que se desenvolve. Não obstante, é conveniente levar em conta que nem todos os turistas se encontram exclusivamente motivados pela cultura, já que alguns o estão em parte, enquanto outros consideram a cultura como vinculada à outra motivação principal e, para outros ainda, a cultura é um fato simplesmente acidental. Schüter (2003, p.70).
\end{abstract}

A gastronomia é uma das mais fascinantes maneiras de se conhecer a alma de um povo, além de ser um diferencial competitivo para o turismo, a gastronomia é um dos instrumentos que revelam as características, traços e cultura de um povo.

Conforme Cavalcante (2009), o festival Brasil Sabor começou em 2006. Nele, ocorre um show de criatividade, variedade, e valorização da culinária nacional. O evento tem como objetivo demonstrar que, além de seus belos roteiros turísticos e de sua valiosa cultura, o Brasil possui uma riqueza de dar água na boca: a gastronomia. Além disso, comprovar que com sua variedade de ingredientes, temperos, aromas, cores e sabores a culinária brasileira é um dos importantes atrativos turísticos que o Brasil tem a oferecer.

As casas participantes oferecem simultaneamente ao público a preços diferenciados, durante todo o período do festival, um prato específico para o evento, que represente da melhor maneira a especialidade da casa e que leve em consideração as características e tradições de cada região ou estado. Os pratos são servidos nos próprios restaurantes tanto no almoço como no jantar, conforme o funcionamento de cada estabelecimento. O festival faz parte do esforço entre a Associação Brasileira de Bares e Restaurantes (ABRASEL), Serviço Brasileiro de 
Apoio ás Micro e Pequenas Empresas (SEBRAE) e Ministério do Turismo, que deu origem ao Movimento Brasil Sabor, um conjunto de ações estratégicas com resultados muito positivos que buscam a promoção e valorização da gastronomia brasileira.

A variedade gastronômica presente na culinária da Capital Federal tem enorme importância no festival Brasil Sabor. Em sua sexta edição, segundo dados de Cavalcante (2009), o festival começou, simultaneamente, em 94 endereços de 68 restaurantes participantes do circuito, ficando claro o aumento da comercialização de pratos e da receita dos empreendimentos envolvidos.

O Cantinho árabe estabelece com objetivo futuro participar do festival de gastronomia Brasil sabor Brasília para ser um instrumento que revela as características, traços e cultura do povo árabe.

\subsection{Administração}

O ser humano sempre teve uma necessidade de organizar as suas atividades e de dividir as tarefas e tomar decisões. Assim, A história da vida humana possui aspectos semelhantes com a administração.

Segundo Maximiano (2000, p. 26), “Administração é um processo de tomar decisões e realizar ações que compreende quatro processos principais interligados: planejamento, organização, execução e controle".

Conforme Stoner e Freeman (1999, p.5), "A administração é o processo de planejar, organizar, liderar e controlar esforços realizados pelos membros da organização e o uso de todos os outros recursos organizacionais para alcançar os objetivos estabelecidos".

Assim, os profissionais devem manter seu foco nesses quatro processos. Porém, administrar é também desenvolver uma percepção para interpretar os objetivos organizacionais e solucionar os possíveis problemas que venham a ocorrer. 
Já Megginson et al (1998, p. 13) trabalham com uma visão mais ampla onde ele define como sendo um:

Trabalho com recursos humanos, financeiros e materiais, para atingir objetivos organizacionais, através do desempenho das funções de planejar, organizar, liderar e controlar. Deve-se notar que a finalidade da administração é estabelecer e alcançar o objetivo, ou objetivos, da organização.

Conclui-se que Administração é o trabalho realizado pelo administrador utilizando eficientemente todas as funções administrativas e também os processos de planejamento, organização, execução e controle e interpretação das informações com o objetivo de atingir a máxima eficiência dentro de todos os departamentos da organização.

\subsection{Processos Administrativos}

Conforme Megginson et al (1998, p.17) afirmam:

Qualquer que seja o tipo de indústria, o nível organizacional ou a atividade envolvida, pelo menos quatro funções devem ser desempenhadas por um administrador: planejamento, organização, liderança e controle das atividades organizacionais.

Maximiano apresenta a seguinte tabela, na qual delimita os quatro processos ou funções que descrevem a ação administrativa:

Quadro 1: Funções ou processos do processo administrativo.

\begin{tabular}{|c|l|}
\hline Processo ou Função & \multicolumn{1}{|c|}{ Descrição } \\
\hline Planejamento & $\begin{array}{l}\text { Planejamento é o processo de definir } \\
\text { objetivos, atividades e recursos. }\end{array}$ \\
\hline Organização & $\begin{array}{l}\text { Organização é o processo de definir o } \\
\text { trabalho a ser realizado e as } \\
\text { responsabilidades pela realização; é também } \\
\text { processo de distribuir os recursos } \\
\text { disponíveis segundo algum critério. }\end{array}$ \\
\hline Direção & $\begin{array}{l}\text { Execução é o processo de realizar atividades } \\
\text { e utilizar recursos para atingir os objetivos. O } \\
\text { processo de execução envolve outros } \\
\text { processos, especialmente o processo de } \\
\text { direção, para acionar os recursos que }\end{array}$ \\
\hline
\end{tabular}




\begin{tabular}{|l|l|}
\hline & realizam as atividades e os objetivos. \\
\hline Controle & $\begin{array}{l}\text { Controle é o processo de assegurar a } \\
\text { realização dos objetivos e de identificar a } \\
\text { necessidade de modificá-los. }\end{array}$ \\
\hline
\end{tabular}

Fonte: (MAXIMIANO, 1990, p.17).

Com o domínio dessas funções, o administrador poderá ter um controle maior sobre as atividades a serem desenvolvidas. Assim, através do planejamento traçado é possível definir os objetivos que se pretende alcançar, organizar o processo de trabalho que deve ser realizado, executar as atividades através dos recursos disponíveis e controlar todas as tarefas a fim de assegurar que as metas sejam alcançadas mesmo que se faça necessário algumas modificações.

Em qualquer organização que os administradores venham a atuar, devem realizar essas quatro funções básicas que contribuem para que o profissional tenha sucesso e alcance os objetivos organizacionais.

\subsection{Funções da Administração}

Para Kwasnicka (1989), As funções da administração consistem em gerência, controle e direção de empresas públicas ou privadas, tendo como objetivo maior produtividade e lucratividade. Para se chegar a isto, o administrador avalia os objetivos organizacionais e desenvolve as estratégias necessárias para alcançá-los. Este profissional. No entanto, não tem apenas esta função teórica, ele é responsável pela implantação de tudo que planejou e, portanto, vai ser aquele que define os programas e métodos de trabalho, avaliando os resultados e corrigindo os setores e procedimentos que estiverem com problemas.

De acordo com Megginson et al (1998, p.16),

A maneira pela qual os administradores exercem seu trabalho tende a variar segundo as funções organizacionais que eles desempenham. A missão ou o propósito das organizações varia bastante. Entretanto, há muitas funções semelhantes que todas as organizações devem desempenhar para levar a cabo sua missão.

Segundo Megginson et al (1998, p.19), 
As funções da administração devem ser desempenhadas por alguém, sempre que houver e onde quer que haja grupos organizados. O exercício de todas essas atividades é de responsabilidade dos administradores. Por serem responsáveis por essas atividades, os administradores planejam e organizam os recursos materiais, financeiros e humanos da organização; contratam o pessoal necessário; lideram, dirigem ou supervisionam 0 desempenho das atividades essenciais; e medem, avaliam, calculam e controlam a execução dessas atividades. O sucesso ou o fracasso de uma organização depende substancialmente da capacidade de seus administradores desempenharem essas funções de maneira eficaz.

Cada administrador exerce suas atividades de acordo com a organização em que atua. Como neste trabalho será elaborado um plano de negócios para um empreendimento que fornece produtos árabes, este incluirá administrar funções que serão detalhadas a seguir.

\subsubsection{Recursos Humanos}

De acordo com Stoner e Freeman (1999, p.276), "A Administração de Recursos Humanos é a função da administração que auxilia administradores na seleção, treinamento e desenvolvimento de membros da organização".

Conforme Nunes (2007), A gestão de recursos humanos consiste num conjunto de funções e atividades que podem ser sintetizadas no seguinte: planejamento de recursos humanos; recrutamento e seleção; integração dos recursos humanos; análise e descrição de funções; avaliação de desempenho; remunerações e incentivos; higiene e segurança no trabalho; formação profissional e desenvolvimento pessoal; controlo e auditoria de recursos humanos.

Para Megginson et al (1998, p.13), "A administração de recursos humanos é um aspecto muito importante da administração: planejamento de pessoal, recrutamento, seleção, treinamento e desenvolvimento de empregados capacitados colocando-os em ambientes produtivos, e recompensando o seu desempenho".

Recursos Humanos ou Gestão de Pessoas é a área responsável em gerir e zelar pelos seres humanos dentro da organização, é a parte que trabalha o recrutamento, a seleção, o treinamento, as recompensas e a avaliação de desempenho dos colaboradores. 


\subsubsection{Marketing}

Kotler (2000, p.30) define que "marketing é o processo de planejar e executar a concepção do preço, a promoção e a distribuição de idéias, bens e serviços para criar trocas que satisfaçam metas individuais e organizacionais". Para Andrade (2002, p.141), marketing "é o processo de administração pelo qual se identificam se antecipam e se satisfazem as necessidades do consumidor, de maneira rentável, otimizando investimentos".

De acordo com Melgar (2001, p.60), "marketing é o conjunto de atividades orientadas a identificar e satisfazer as necessidades e desejos, atuais e potenciais dos consumidores, de forma planejada e rentável".

Segundo os autores citados é possível concluir que marketing é a função administrativa responsável por interpretar e despertar o desejo do consumidor, dessa maneira é feito o processo de planejar e executar para que seja gerado preço, promoção e distribuição de idéias, bens e serviços, criando e expandindo a demanda de maneira rentável.

Para Cobra (1997 p.21) "a atividade de vendas é classificada como ferramenta promocional entre propaganda, promoção de vendas, merchandising, relações públicas". Ainda para o autor "a venda não é uma ciência e talvez nem mesmo seja uma arte, o que ela exige é a aplicação de métodos adequados acompanhados sempre de uma boa doze de criatividade". (COBRA 1997, p.474)

Segundo Kotler (2000, p.616):

A promoção de vendas consiste em um conjunto diversificado de
ferramentas de incentivo, a maioria de curto prazo, projetadas para
estimular a compra mais rápida ou em maior quantidade de produtos ou
serviços específicos, pelo consumidor ou pelo comércio.

A venda é mostrada como uma ferramenta promocional na qual é um incentivo, em curto prazo, para estimular o consumidor à compra mais rápida ou em maior quantidade. 


\title{
2.6.2.1 Mix de Marketing
}

Kotler (2000, p.37) define mix de marketing como "o conjunto de ferramentas de marketing que a empresa utiliza para perseguir seus objetivos de marketing no mercado-alvo. Conforme Kotler (2000, p.37), "McCarthy classificou essas ferramentas em quatro grupos amplos que denominou como 4Ps do marketing: produto, preço, praça e promoção"

Segundo Cobra (1997, p. 28), "O marketing-mix, ou composto de marketing é apresentado em quatro funções básicas: Produto, Ponto, Preço e Promoção, onde todos os elementos do composto foram criados e estabelecidos para atender ao mercado-alvo".

De acordo com Kotler (2000, p.37) "Decisões de mix de marketing devem ser tomadas para que se exerça influência sobre os canais comerciais, bem como seus consumidores finais"

Para Cobra (1997, p. 29),

\begin{abstract}
Produto ou serviço é dito certo ao consumo quando atende às necessidades e desejos de seus consumidores-alvos. Um produto certo deve ter: Qualidade e padronização - em termos de características, desempenhos e acabamentos; Modelos e tamanhos - que atendam às expectativas e necessidades; e Configuração - apresentação do produto em termos de apresentação física, embalagem, marca e serviço. (...) Ponto o produto ou serviço só tem utilidade se posicionado junto ao seu mercado consumidor. A escolha do ponto para o produto ou serviço relaciona-se com a escolha do canal de distribuição: atacado, varejo ou distribuidor; ao transporte e a armazém. (...) Preço do produto deve ser certo, deve estar no ponto certo e deve transferir a posse do preço certo. O preço pode ser considerado: posto na fábrica; posto no cliente; atacadista, varejista ou distribuidor; líquido com desconto ou bruto sem desconto; desconto por quantidade, por condições de pagamento etc. (...) Promoção e o composto promocional do produto ou serviço compreende a publicidade, as relações públicas, a promoção de vendas, a venda pessoal e o merchandising.
\end{abstract}

Percebe-se que o mix de marketing é muito importante para quem pretende criar um negócio, porque através dessa ferramenta que será trabalhado vários aspectos essenciais para organização: variedade de produto, qualidade, marca preço, descontos, condições de financiamentos, promoção de vendas, publicidade, marketing direto, locais, estoque, transporte etc. 


\subsubsection{Produção}

"A administração da produção trata da maneira pela qual as organizações produzem bens e serviços”. (SLACK et al, 2002, p. 30).

De acordo com Pozo (2004, p. 112):

Toda organização industrial propõe-se a executar duas coisas: a primeira é produzir seu produto; a outra é comercializar o que produz. O sistema de produção requer a obtenção e utilização dos recursos produtivos, que incluem: mão-de-obra, materiais, edifícios, equipamentos e capital. A comercialização exige a interação a outras atividades, tais como: Pesquisa de Mercado, Promoção, Vendas, Distribuição e Pós-Vendas. Cada vez mais, a distinção entre serviços e produtos é ao mesmo tempo difícil e não particularmente útil. Tecnologias de informação e comunicação estão até desafiando algumas das conseqüências da intangibilidade dos serviços. Algumas autoridades percebem a razão essencial de todos os negócios, e, portanto dos processos produtivos, como "servir aos clientes". Dessa forma, argumentam, todas as operações são fornecedoras de serviços, que podem também produzir produtos como forma de servir seus clientes. Tratamos administração da produção como algo relevante para todas as organizações, sejam elas fabricantes de produtos ou prestadoras de serviços. Slack et al (2002, p.42).

Fica claro, assim, que a função produção é a responsável por produzir os bens e serviços.

\subsubsection{Logística}

Conforme define Pozo (2004, p.13):

A Logística Empresarial trata de todas as atividades de movimentação e armazenagem que facilitam o fluxo de produtos desde o ponto de aquisição da matéria-prima até o ponto de consumo final, assim como dos fluxos de informação que colocam os produtos em movimento, com o propósito de providenciar níveis de serviço adequados aos clientes a um custo razoável.

Já Ballou (1993, p.17) define que:

A logística empresarial estuda como a administração pode promover melhor nível de rentabilidade nos serviços de distribuição aos clientes e consumidores, através de planejamento, organização e controle efetivos 
para as atividades de movimentação e armazenagem que visam facilitar 0 fluxo de produtos. A logística Empresarial estuda como a Administração pode promover melhor nível de rentabilidade no processo de pleno atendimento do mercado e satisfação completa ao cliente, com retorno garantido ao empreendedor, através do planejamento, organização e controles efetivos para as atividades de armazenagem, programas de produção e entregas de produtos e serviços com fluxos facilitadores do sistema organizacional e mercadológico. A logística é uma atividade vital para a organização. A logística empresarial trata de todas as atividades de movimentação e armazenagem que facilitam o fluxo de produtos desde 0 ponto de aquisição da matéria-prima até o ponto de consumo final, assim como fluxos de informações que colocam os produtos em movimento, com o propósito de providenciar níveis de serviço adequados aos clientes a um custo razoável. Pozo (2004, p.14).

Segundo Kotler (2000, p.558):

A logística de mercado envolve o planejamento, a implementação e o controle dos fluxos físicos de materiais e de produtos finais entre os pontos de origem e os pontos de uso, com o objetivo de atender às exigências dos clientes e de lucrar com esse atendimento.

Logística é a função responsável pelas atividades de movimentação e armazenagem, facilitação do fluxo desde a matéria-prima até o consumo final, promovendo assim um melhor nível de rentabilidade nos serviços de distribuição aos consumidores, visando facilitar o fluxo de produtos para que o retorno seja garantido para o empreendedor.

\subsubsection{Contabilidade}

Conforme Marion (1998, p.24) define:

A contabilidade é o instrumento que fornece o máximo de informações úteis para a tomada de decisões dentro e fora da empresa. Ela é muito antiga e sempre existiu para auxiliar as pessoas a tomarem decisões. Com o passar do tempo o governo começa a utilizar-se dela para arrecadar impostos e a tornar obrigatória para a maioria das empresas.

Já Neves e Viceconti (1997, p.1) definem quem:

A contabilidade é uma ciência que desenvolveu uma metodologia própria com a finalidade de: controlar o patrimônio das aziendas; apurar o redito das atividades das aziendas e prestar informações às pessoas que tenham interesse na avaliação da situação patrimonial e do desempenho dessas entidades. 
A contabilidade auxilia os administradores para captar, registrar, resumir e interpretar as situações patrimoniais, financeiras e econômicas auxiliando na tomada de decisões dentro e fora da organização.

\subsubsection{Financeira}

Segundo Brito e Cardoso(2004, p.20):

A função financeira compreende um conjunto de atividades relacionadas com a gestão dos fundos movimentados por todas as áreas da empresa. Essa função é responsável pela obtenção dos recursos necessários e pela formulação de uma estratégia voltada para a otimização do uso desses fundos.

Para Brito e Cardoso (2004, p. 20):

O objetivo básico implícito nas decisões de administração financeira é a maior rentabilidade possível sobre o investimento efetuado por indivíduos ou instituições caracterizados como proprietários/acionistas ordinários, no caso de uma sociedade anônima.

A função financeira é uma das funções que necessita de atenção especial, pois é ela que irá permitir que a empresa faça investimentos em outras áreas como contratação de pessoal, divulgação da empresa entre outras.

De acordo com Brito e Cardoso (2004), o período de recuperação do investimento (Payback) é a maneira mais simples de avaliação. Este é o tempo necessário para que os investidores retirem o valor desembolsado inicialmente.

\subsection{Administração no século XXI}

O século XXI vai marcar o aprofundamento da globalização na economia, as empresas terão de rever os conceitos que dirigem a sua administração. Para 
Kotler, (2000, p.49) "As empresas estão fazendo muita auto-análise e empresas muitíssimo respeitadas estão mudando em vários aspectos".

O autor ainda apresenta algumas tendências atuais para as empresas modernas são elas: reengenharia, terceirização, e-commerce, benchmarking, alianças, parceiros-fornecederos, centradas no mercado, globais e locais, descentralizadas. Além dessas tendências apresentadas é importante ressaltar o capital intelectual das empresas que passa a ser valorizado e se torna uma peça fundamental no mercado que se torna mais competitivo.

Conforme Megginson et al (1998, p. 574) "as oportunidades maiores para futuras carreiras em administração estarão nas posições de colarinho branco em indústrias de prestação de serviços”. De acordo com Megginson et al (1998, p.574) "Os cargos de colarinho branco incluem os ocupados pelo pessoal técnico e profissional, gerentes e administradores, pessoal de vendas e empregados de escritório".

Assim as empresas não são mais voltadas apenas para o operacional das fábricas, pois com a valorização dos cargos de gerência torna-se necessário que o profissional esteja em constante aprendizado e sempre atento as mudanças e tendências de mercado.

A administração tem mostrado um crescimento para as empresas que atuam com serviços e algumas tendências como à reengenharia, terceirização, alianças, descentralização, novos estilos de liderança, benchmarking, descentralização e acesso a informação que se torna cada vez mais fácil com a globalização.

\subsection{Empreendedorismo}

O economista Cantillon (1755), que foi o primeiro a definir significados e conceitos, defendia o termo empreendedorismo com sendo referente às pessoas que compravam matérias-primas para vender a terceiros, depois de manuseá-las identificando, então, uma oportunidade de negócio e assumindo riscos. JeanBaptiste Say (1803), também economista, com uma visão mais moderna, considerou 
que a criação de novos empreendimentos resultaria em desenvolvimento econômico.

Já Dornelas (2001, pág. 29), nos mostra que empreendedorismo:

É o processo de criar algo novo com valor dedicando o tempo e os esforços necessários, assumindo os riscos financeiros, psíquicos e sociais correspondentes e recebendo as conseqüentes recompensas da satisfação e independência econômica e pessoal.

Então, conclui-se que empreender é a capacidade de ter grandes idéias, ter atitude, aproveitar oportunidades, resolver problemas, criar inovando, sonhar e realizar.

A Pesquisa do Serviço Brasileiro de apoio à Micro e Pequenas Empresas (SEBRAE 2005) revela que no Brasil, a pequena empresa representa 98,5 \% das empresas existentes no país, $60 \%$ da oferta de emprego e $21 \%$ do Produto Interno Bruto (PIB). O índice de mortalidade destas empresas é alto devido a fatores como: habilidade gerencial, conhecimento do mercado, uma boa estratégia de vendas, capacidade empreendedora, aproveitamento das oportunidades de negócio, perseverança, capacidade de liderança e logística operacional representada por escolha de um bom administrador entre outros.

Para Pereira (1995), Algo essencial para que a pessoa seja empreendedora é que ela deve ser inovadora. Se o empresário compra um negócio e não faz nenhuma alteração no modo de tratar seus clientes, ou então na política da empresa, por exemplo, ela não é considerada empreendedora.

Conforme Filion (1991), "o empreendedor é o inovador com características que compreendem criatividade, persistência, liderança, iniciativa, flexibilidade em conduzir situações e habilidades em utilizações de recursos”.

Já Dornelas (2001, pág. 39), nos mostra que existe alguns tipos de habilidades necessárias em empreendedorismo são elas técnicas, administrativas e pessoais. Habilidades técnicas: redação, expressão oral, monitoramento do ambiente, administração comercial técnica, tecnologia, interpessoal, capacidade de ouvir, capacidade de organizar, construção de rede de relacionamentos, estilo administrativo, treinamento e capacidade de trabalho em equipe.

Habilidades administrativas: planejamento e estabelecimento de metas, 
capacidade de tomar decisões, relações humanas, marketing, finanças, contabilidade, administração, controle, negociação, lançamento de empreendimento e administração do crescimento.

Habilidades empreendedoras pessoais: controle interno e de disciplina, capacidade de correr riscos, inovação, orientação para mudanças, persistência, liderança visionária e habilidade para administrar mudanças.

Conforme Filion (1991), por ser simples e abrangente um empreendedor é uma pessoa que imagina, desenvolve e realiza visões.

Para que o futuro empreendedor possa então alcançar seus objetivos e metas através da sua idéia empreendedora, deverá utilizar-se de um Plano de Negócios, que é a ferramenta necessária para o sucesso de uma nova empresa. Com ele, o empreendedor poderá, antes de implantar seu projeto, ter conhecimento se o seu empreendimento será viável ou não e se o mesmo poderá se sobressair no mercado.

\title{
2.9 Plano de Negócios
}

\begin{abstract}
A elaboração de um Plano de negócio é fundamental para o empreendedor, não somente para a busca de recursos, mas principalmente, como forma de sistematizar suas idéias e planejar de forma mais eficiente, antes de entrar de cabeça em um mercado sempre competitivo. (FELIPINI, 2005, p. 1).
\end{abstract}

Para o autor, um Plano de Negócios é basicamente um instrumento de planejamento, no qual as principais variáveis envolvidas em um empreendimento são apresentadas de forma organizada.

De acordo com Dornelas (2005, p. 1), criar um Plano de Negócios se faz necessário no processo de planejamento de um empreendimento, uma vez que:

Com o Plano de Negócios é possível identificar os riscos e propor planos para minimizá-los e até mesmo evitá-los; identificar seus pontos fortes e fracos em relação à concorrência e o ambiente de negócio em que você atua; conhecer seu mercado e definir estratégias de marketing para seus produtos e serviços; analisar o desempenho financeiro de seu negócio, avaliar investimentos, retorno sobre o capital investido; enfim, você terá um poderoso guia que norteará todas as ações de sua empresa.

Desta forma, considera-se o Plano de Negócios material essencial para o 
futuro empreendedor uma vez que com ele, o risco de mortalidade das empresas pode ser amenizado.

O principal usuário do Plano de Negócios é o próprio empreendedor, que está diante de uma ferramenta que o faz mergulhar profundamente na análise do seu negócio, diminuindo sua taxa de risco e subsidiando suas decisões que podem até ser de não abrir uma empresa, ou de não lançar um novo produto. (DOLABELA, 2006, p. 77).

Contudo, o Plano de Negócios não é utilizado apenas para a empresa e sim para todos que tem alguma ligação com a mesma. Pode-se dizer que o Plano de Negócios é como uma bússola, pois através deste é possível pensar no futuro da empresa e definir para onde ir e o que fazer para diminuir os riscos e incertezas até que se atinjam os objetivos traçados.

O plano de Negócios elaborado nesse trabalho terá como base as idéias de SALIM (2005), para ele um plano de negócio deve conter: Sumário Executivo, Resumo da Empresa, Produtos e Serviços, Plano de Marketing, Estrutura Operacional, Organização e Gerência e Plano Financeiro.

\subsubsection{Sumário Executivo}

O Sumário executivo é a apresentação da empresa. O objetivo dessa etapa do trabalho é "retratar a empresa e o negócio que se pretende empreender". (Salim et al, 2005, p.42).

"O sumário executivo é o resumo do plano de negócios. Não se trata de uma introdução ou justificativa e, sim, de um sumário contendo seus pontos mais importantes." Rosa (2007, pág. 12)

Nesse tópico deve-se escrever de forma sucinta tudo o que contém no plano de negócios, por isso o sumário executivo só deve ser realizado após o termino do plano de negócios. 


\subsubsection{Resumo da Empresa}

Rosa (2007) pontua que no resumo da empresa devem ser descriminados, os dados dos responsáveis pela empresa, nome da empresa e sua forma jurídica.

De acordo com Salim et al (2005, p.56), esta seção deve ter: "Sumário explicativo sobre o que a empresa ou unidade de negócio fará. Qual o produto ou serviço que será comercializado, quem são os proprietários da empresa, seus currículos, a forma como vão dividir suas responsabilidades na empresa e realizar seu gerenciamento".

\subsubsection{Produtos e Serviços}

Para melhor definição dos produtos e serviços que serão oferecidos pela empresa, segundo Bangs (1999, p.36), se faz necessário o seguinte questionamento:

1. O que você está vendendo?

2. Quais os benefícios do que você está vendendo?

3. De que maneira os seus produtos e/ou serviços diferem dos da concorrência?

4. Se seu produto é novo, atualizado ou de alguma forma digno de nota, o que o torna diferente? Desejável?

5. Se sua linha de produto ou serviço não é especial, porque as pessoas comprariam de você? Comodidade? Uma linha ampla de produtos? Conhecimento especializado de como utilizar os produtos que você vende?

Um dos aspectos mais importante da gerência de um negócio é dar ao mercado razões para comprar seus produtos - e uma das melhores e constituída pelos benefícios que você oferece para atender aos desejos dos consumidores. (Bangs, 1999, p.36). 
Nessa etapa relacionam-se os produtos/serviços que serão oferecidos pela empresa.

\subsubsection{Plano de Marketing}

Para se entender a finalidade de um plano de marketing, é necessário identificar a definição do termo, que, nos dias atuais, vai além da propaganda e promoção para a venda de produtos e serviços.

Limeira (2006, p.2) conceitua marketing como sendo a "função empresarial que cria continuamente valor para o cliente e gera vantagem competitiva duradoura para a empresa, por meio da gestão estratégica das variáveis controláveis de marketing; produto, preço, praça, comunicação e distribuição”.

O planejamento de Marketing é necessário para se estabelecer os objetivos, as metas e as estratégias da empresa, estando em perfeita harmonia com o plano estratégico geral da mesma em seus objetivos e pretensões.

Sobre o desenvolvimento de planos de marketing e sua importância, Las Casas (2001, p. 21) observa que "elaborar planos de marketing contrapõe-se ao improviso, situação que pode prejudicar o andamento dos negócios”. E, ainda, o mesmo autor ressalta: "no entanto, muitos sinais do ambiente podem ser detectados antecipadamente, com o habito do planejamento, uma vez que a atividade exige sintonia com o mercado e constante adaptação”. (Las Casas, 2001, p.21)

Nessa etapa do plano de negócios serão determinadas as estratégias de marketing do Cantinho Árabe, bem como a identificação das suas forças e fraquezas, suas oportunidades, ameaças e o marketing mix (produto, preço, praça e promoção). 


\title{
2.9.5 Estrutura Operacional
}

\author{
Nessa etapa do plano, de acordo com Pereira e Santos (1995, p.171), "o \\ empreendedor deve estudar e decidir sobre os aspectos técnicos do \\ empreendimento".
}

Rosa (2007, pág. 40)

\begin{abstract}
Por meio do layout ou arranjo físico, você irá definir como será a distribuição dos diversos setores da empresa, de alguns recursos (mercadorias, matérias-primas, produtos acabados, estantes, gôndolas, vitrines, prateleiras, equipamentos, móveis, matéria-prima etc.) e das pessoas no espaço disponível. Um bom arranjo físico traz uma série de benefícios, como: aumento da produtividade; diminuição do desperdício e do retrabalho; maior facilidade na localização dos produtos pelos clientes na área de vendas; melhoria na comunicação entre os setores e as pessoas.
\end{abstract}

Observa-se, dessa forma, que a estrutura operacional trata da estrutura interna e externa da empresa, relacionando-se aqui, itens físicos indispensáveis para a abertura e funcionamento do empreendimento.

\subsubsection{Organização e gerência}

O tópico organização e gerência são compostos pela estrutura organizacional da empresa (critérios de recompensa, treinamento de funcionários) e organograma. Salim (2005).

Para Rosa (2005), nesta seção deve se dimensionar sua equipe de trabalho, relacionando número de empregados, cargos, salários e encargos sociais esperados.

A organização e gerência e parte do plano, aonde se define o organograma da empresa, quantos funcionários serão necessários e forma que serão treinados para exercer as funções que lhe cabem. 


\title{
2.9.7 Plano Financeiro
}

Salim et al (2005, p. 105) considera o planejamento financeiro importante porque:

\begin{abstract}
É nele que vamos juntar todas as despesas. Desde aquelas que foram feitas para iniciar o negócio, constituir sua base, até aquelas que estarão sendo feitas em plena fase operacional para mantê-lo vivo e com funcionamento regular de suas atividades de venda e de produção. Também vamos alinhar as receitas obtidas com a venda de nossos produtos, serviços e soluções e, finalmente, vamos avaliar como fica o conjunto e qual o saldo disso tudo.
\end{abstract}

Ainda segundo Salim et al (2005, p.105), o planejamento financeiro deverá responder às seguintes perguntas:

1. A empresa é lucrativa?

2. Depois de quanto tempo após a sua constituição?

3. Quanto será necessário investir para que seja possível chegar ao ponto em que a empresa seja auto-sustentável?

Pode-se concluir que para verificar a viabilidade de abertura de um empreendimento, se faz necessário um plano financeiro contendo os pressupostos financeiros (remuneração e encargos), o fluxo de caixa (atividades operacionais, investimentos e financiamentos) e os indicadores (break-even point) e (payback period). 


\title{
3. MÉTODOS E TÉCNICAS DE PESQUISA
}

Este capítulo se propõe a apresentar os métodos e técnicas utilizados para a realização do estudo proposto. Segundo Dencker (1998, p. 85), "descrever as etapas metodológicas significa especificar: os estudos exploratórios já realizados ou a realizar; procedimentos de levantamento, análise e interpretação; a descrição do tratamento que será dado aos dados e as delimitações da pesquisa em termos de variáveis a serem controladas".

Para Dencker (1998, p. 86):

\begin{abstract}
A escolha da metodologia adequada irá variar conforme os objetivos da pesquisa e o problema que está sendo investigado. Conforme o dado a ser observado, o pesquisador selecionará o procedimento adequado efetuando as adaptações necessárias. As metodologias não se excluem, mas se complementam. Em um projeto, conforme a fase serão empregados diferentes tipos de pesquisa. Compete ao pesquisador a escolha de tipo mais adequado ao objeto de estudo e a cada fase de pesquisa
\end{abstract}

Método consiste, portanto, no momento em que se definem: os métodos e instrumentos utilizados de maneira a explicitar formas e seqüências que serão utilizadas no desenvolvimento das atividades da pesquisa a ser realizada, executada.

Para Dencker (1998, pág. 86) "um projeto de pesquisa não é necessariamente quantitativo ou qualitativo. O que define o tipo de pesquisa a ser usado é a metodologia adequada são os paradigmas adotados pelo pesquisador e a natureza do problema que se pretende investigar".

Esse trabalho foi desenvolvido no período de abril a junho de 2009, com o intuito de obter embasamento teórico e prático para criação de um plano de negócios de um empreendimento que fornece produtos árabes para que posteriormente seja viável a abertura da empresa de forma planejada. Assim, foi preciso um período integral para execução do trabalho de forma eficiente e eficaz.

Para alcançar os objetivos específicos - identificar a organização e os processos de um empreendimento que fornece produtos árabes; analisar o mercado consumidor, fornecedor e concorrentes no contexto do turismo gastronômico e desenvolver o plano de negócios - foram adotados os seguintes procedimentos: 
$\checkmark$ Pesquisa bibliográfica: construção da revisão de literatura e coleta de dados secundários sobre os temas: Turismo, Turismo Cultural, Festival Gastronômico, Administração, Processos Administrativos, Recursos Humanos, Marketing, Produção, Logística, Contabilidade, Financeira, Administração do século XXI, Empreendedorismo, Plano de Negócios, Sumário Executivo, Resumo da empresa, Produtos e Serviços, Plano de Marketing, Estrutura Operacional, Organização e Gerência e Plano Financeiro.

$\checkmark$ Pesquisa documental: utilização de documentos para obtenção de dados secundários-: dados estatísticos do IBGE e SEBRAE.

$\checkmark$ Pesquisa participante: participação do pesquisador como cliente das empresas na mesma área de atuação do empreendimento proposto, com o objetivo de compreender aspectos da dinâmica de funcionamento das organizações.

$\checkmark$ Pesquisa interativa: contato com possíveis fornecedores e levantamento de dados através da internet (preço dos produtos e analise dos melhores produtos a serem fornecidos aos clientes).

$\checkmark$ Pesquisa de mercado: foi feito um estudo exploratório, através de um roteiro de entrevista aplicado ao proprietário de um empreendimento que fornece produtos árabes, permitindo dessa forma um conhecimento amplo sobre o comércio varejista em Brasília (produto, preço, praça, promoção).

$\checkmark$ Coleta de dados: aplicação de questionários a potenciais clientes, moradores da Asa Sul Brasília- DF, dessa forma foi possível identificar condições de mercado relativas ao negócio proposto;

Após a aplicação dos questionários foi realizada uma análise dos dados de forma estatística e apresentado os resultados alcançados através de gráficos.

$\checkmark$ Elaboração de um plano de negócios considerando as informações obtidas no referencial teórico e na análise de dados para verificar a viabilidade de implantação de do empreendimento proposto.

O universo da pesquisa foi à população de Brasília. A amostragem da pesquisa foi não-probabilística (por julgamento), a amostra obtida para o estudo foi de 50 respondentes, o número definido traz representatividade para a pesquisa considerando o prazo. 
"A finalidade do questionário foi obter, de maneira sistemática e ordenada, informações sobre as variáveis que intervêm em uma investigação, em relação a uma população ou amostra determinada". Dencker (1998, p. 146).

A coleta foi realizada no período entre 27 de abril a 08 de maio de 2009 , foram coletados dados com cidadões de Brasília. Em relação aos dados coletados a partir dos questionários aplicados aos potenciais clientes, foram analisados estatisticamente e apresentados em gráficos com o intuito de identificar as necessidades, desejos e carências existentes no mercado e também foram analisados de forma qualitativa no que diz respeito ao conteúdo para elaboração do plano de negócios, sendo assim uma pesquisa qualitativa e quantitativa. 


\section{APRESENTAÇÃO E ANÁLISE DOS DADOS}

Os dados apresentados foram coletados a partir de um questionário aplicado com 50 indivíduos na cidade de Brasília no período entre 27 de abril a 08 de maio de 2009, buscando identificar sua percepção em relação aos empórios árabes existentes na cidade.

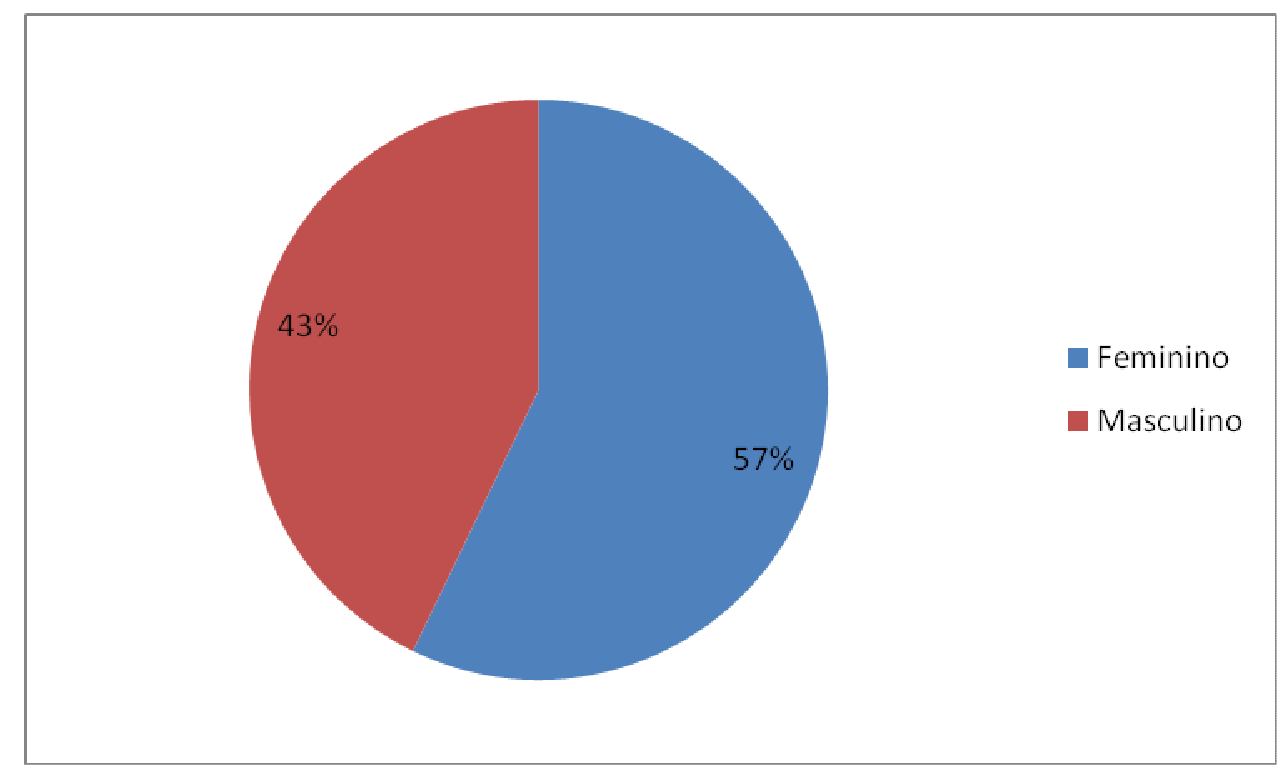

Figura 1: Gênero dos entrevistados

Fonte: elaborado pela autora a partir dos dados coletados.

Dos entrevistados, $57 \%$ eram do gênero feminino e $43 \%$ do gênero masculino. 


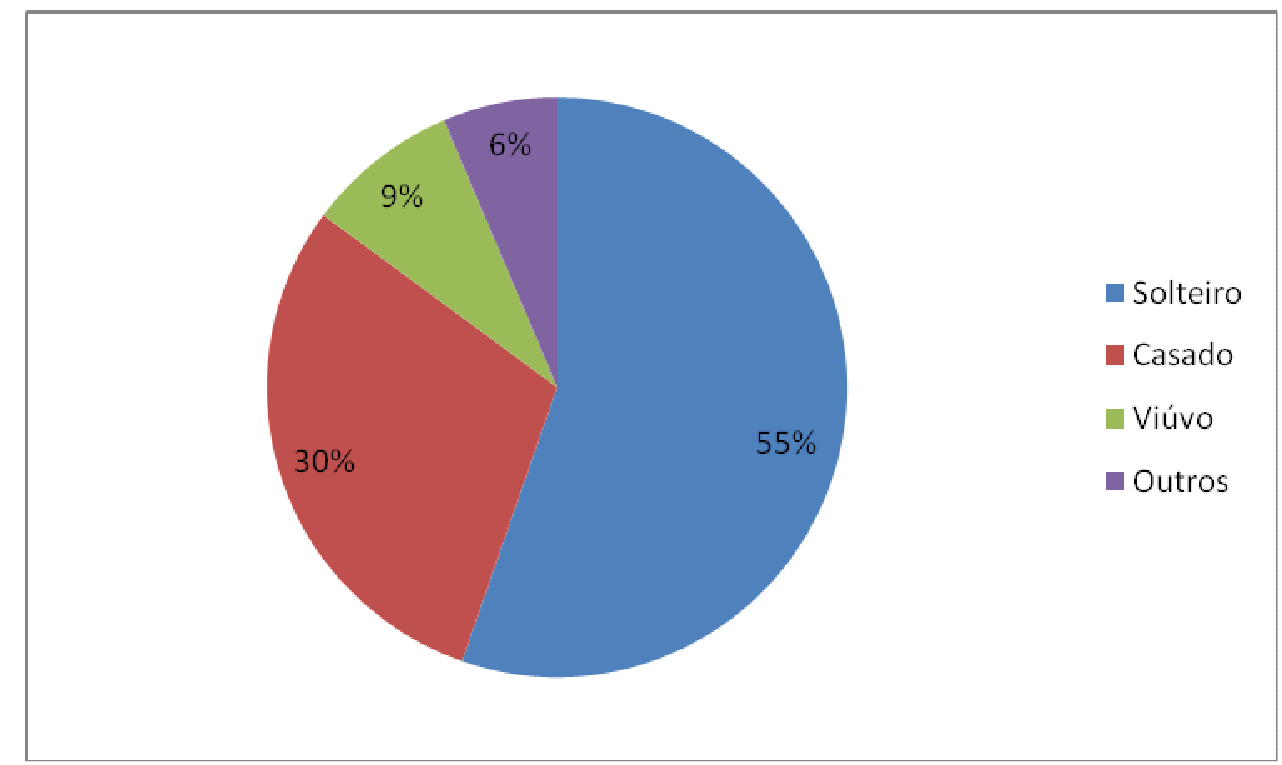

Figura 2: Estado Civil

Fonte: elaborado pela autora a partir dos dados coletados.

Em relação ao estado civil dos entrevistados, mostra-se que 55\% são solteiros, $30 \%$ são casados, $9 \%$ são viúvos e $6 \%$ se classificam em outro estado civil.

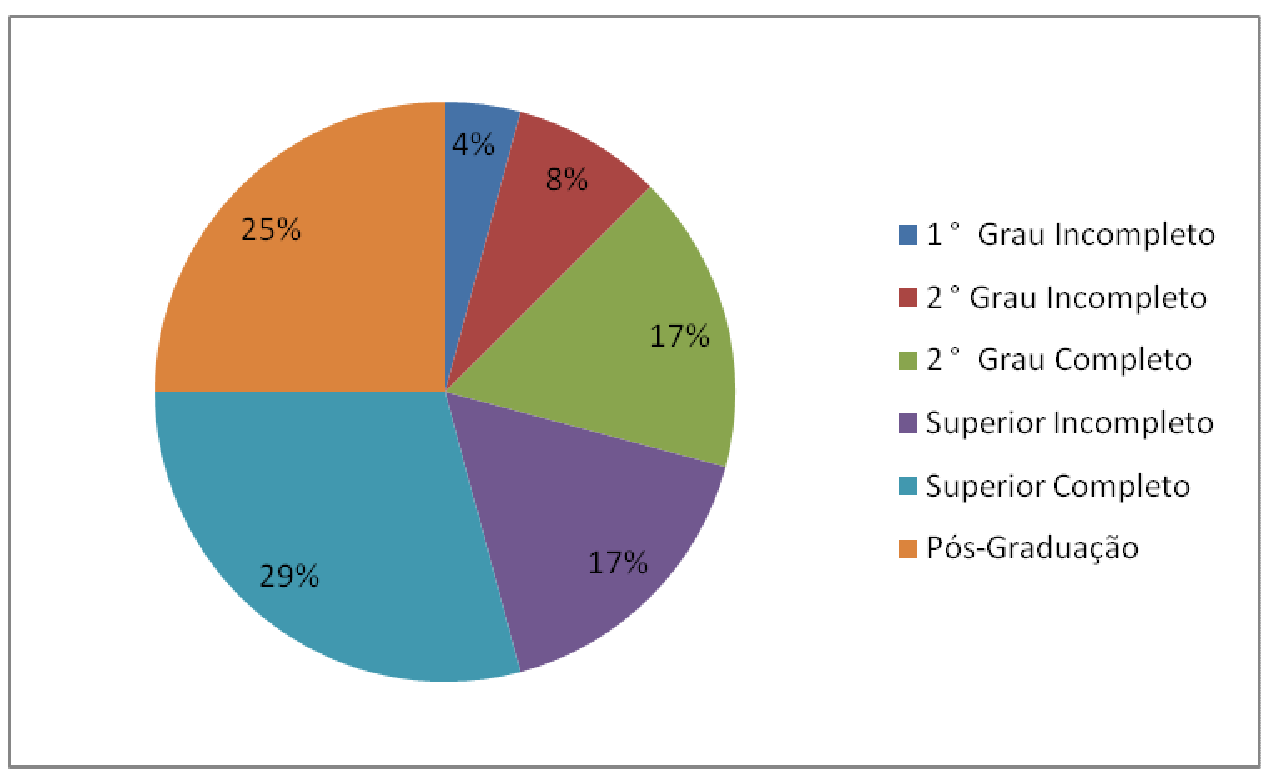

Figura 3: Grau de Escolaridade

Fonte: elaborado pela autora a partir dos dados coletados.

A escolaridade dos entrevistados foi: $25 \%$ com pós-graduação, $29 \%$ com superior completo, $17 \%$ com superior incompleto, 17\% com ensino médio completo, $8 \%$ com ensino médio incompleto e $4 \%$ com ensino fundamental incompleto. 


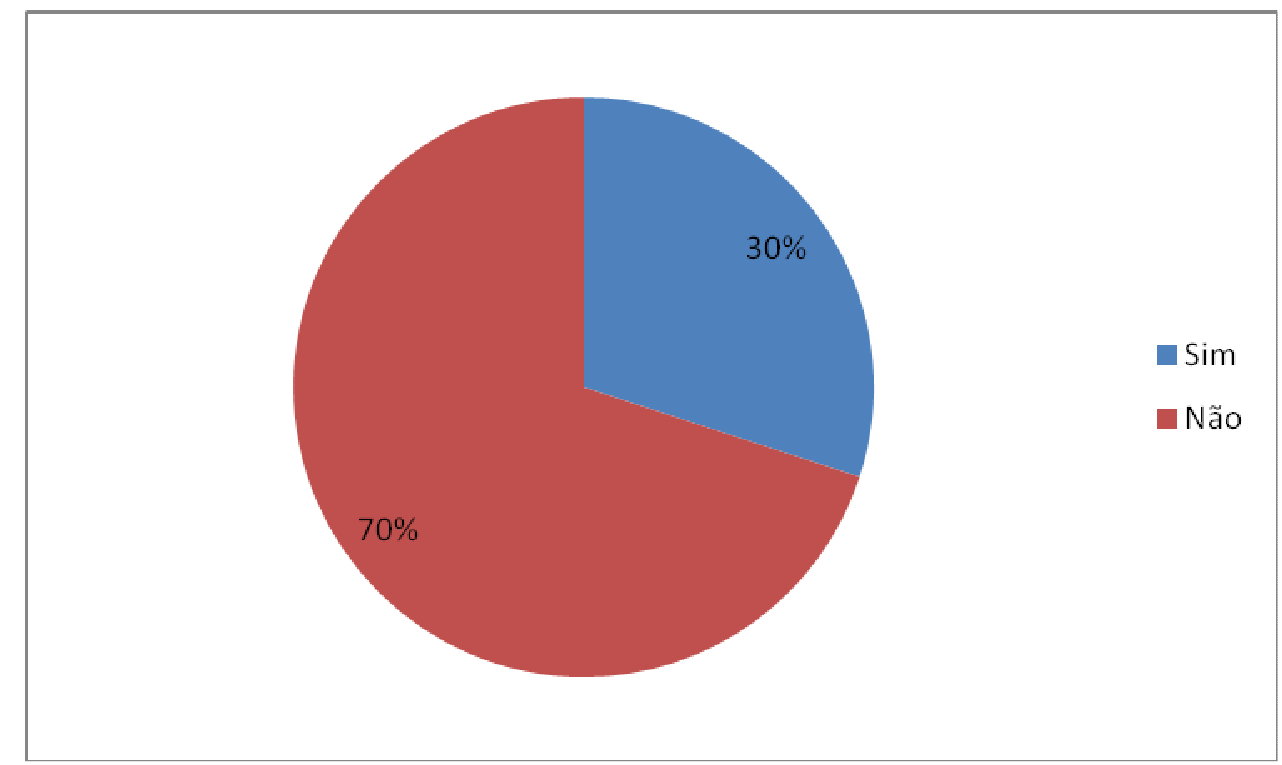

Figura 4: 0 entrevistado já fez compras em algum empório árabe na cidade de Brasília? Fonte: elaborado pela autora a partir dos dados coletados.

Quando perguntado aos entrevistados se já fizeram compras em algum empório árabe na cidade de Brasília, 70\% responderam que não e 30\% responderam que sim.

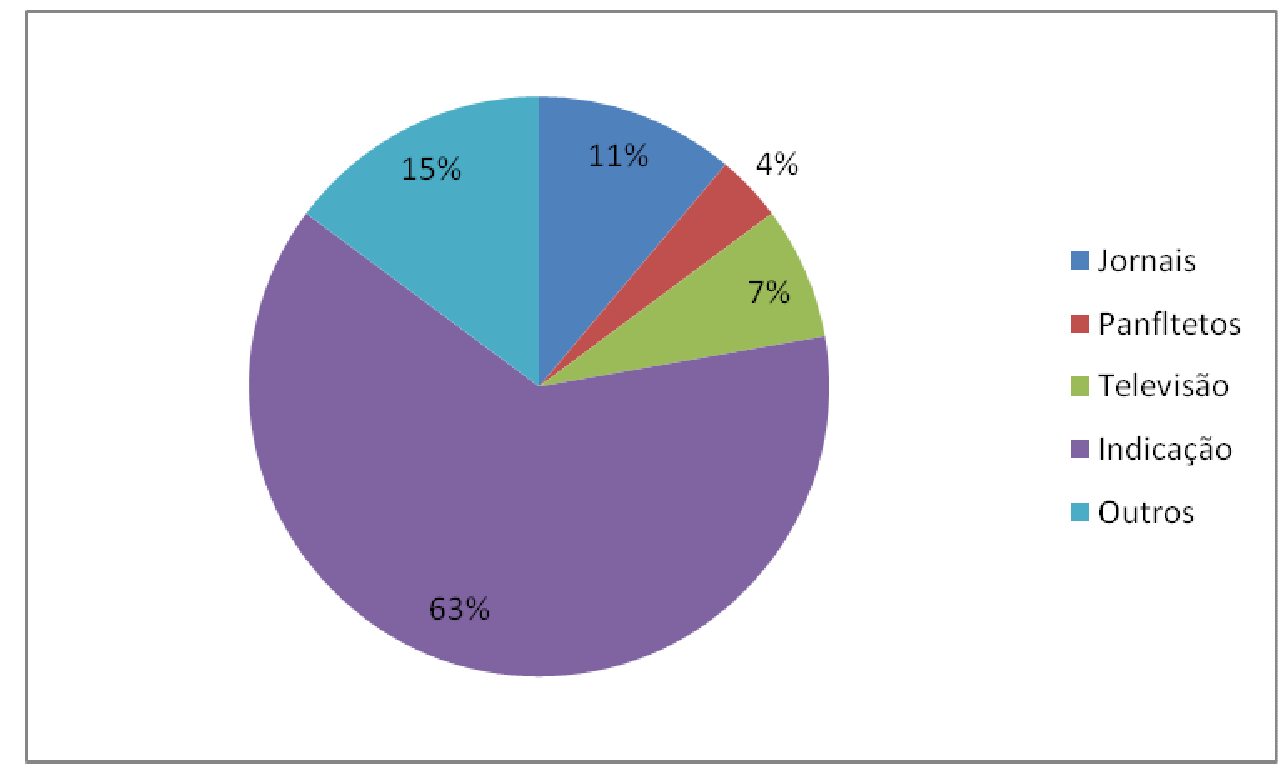

Figura 5: Como o entrevistado ficou sabendo da existência de um empório árabe? Fonte: elaborado pela autora a partir dos dados coletados.

A partir da pergunta "como o entrevistado ficou sabendo da existência de um empório árabe", foi possível constatar que $63 \%$ souberam através de indicação, $11 \%$ 
através de jornais, $7 \%$ de televisão, $4 \%$ de panfletos e $15 \%$ ficaram sabendo de outras formas.

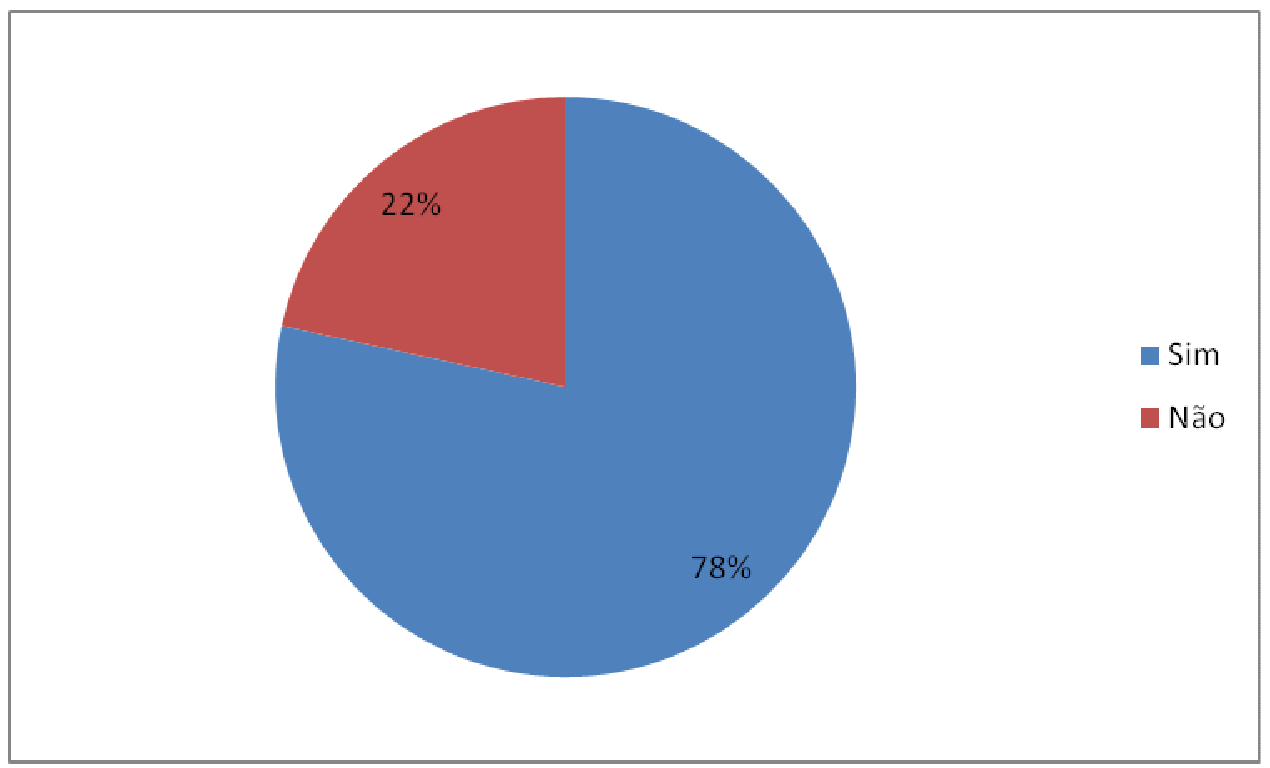

Figura 6: 0 entrevistado tendo preferência por um empório estaria disposto a conhecer outros?

Fonte: elaborado pela autora a partir dos dados coletados.

Dos entrevistados, $78 \%$ estariam dispostos a conhecer outro empório e $22 \%$ não.

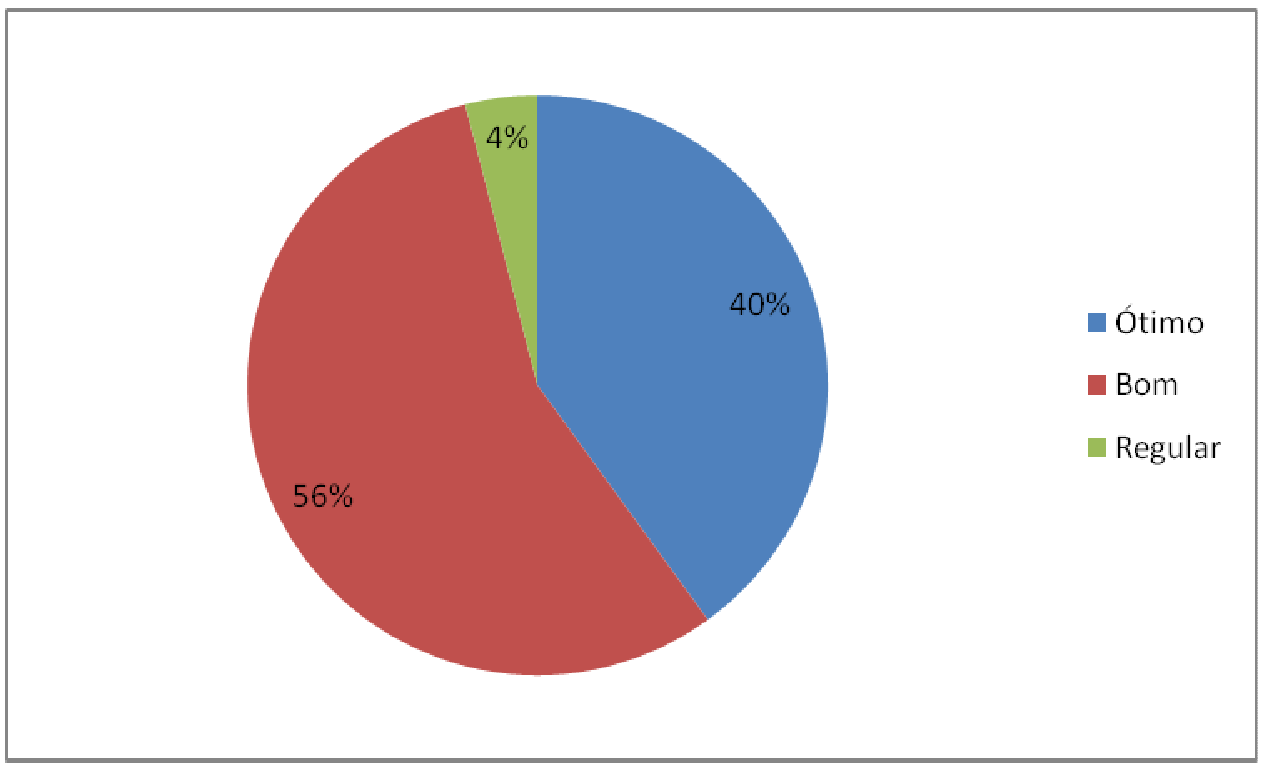

Figura 7: Como o entrevistado classificaria os serviços prestados e os produtos oferecidos pelos empórios que já freqüentou?

Fonte: elaborado pela autora a partir dos dados coletados. 
Os entrevistados que já conheciam algum empório árabe classificaram os serviços prestados e produtos da seguinte maneira: $56 \%$ bom, $40 \%$ ótimo e $4 \%$ regular.

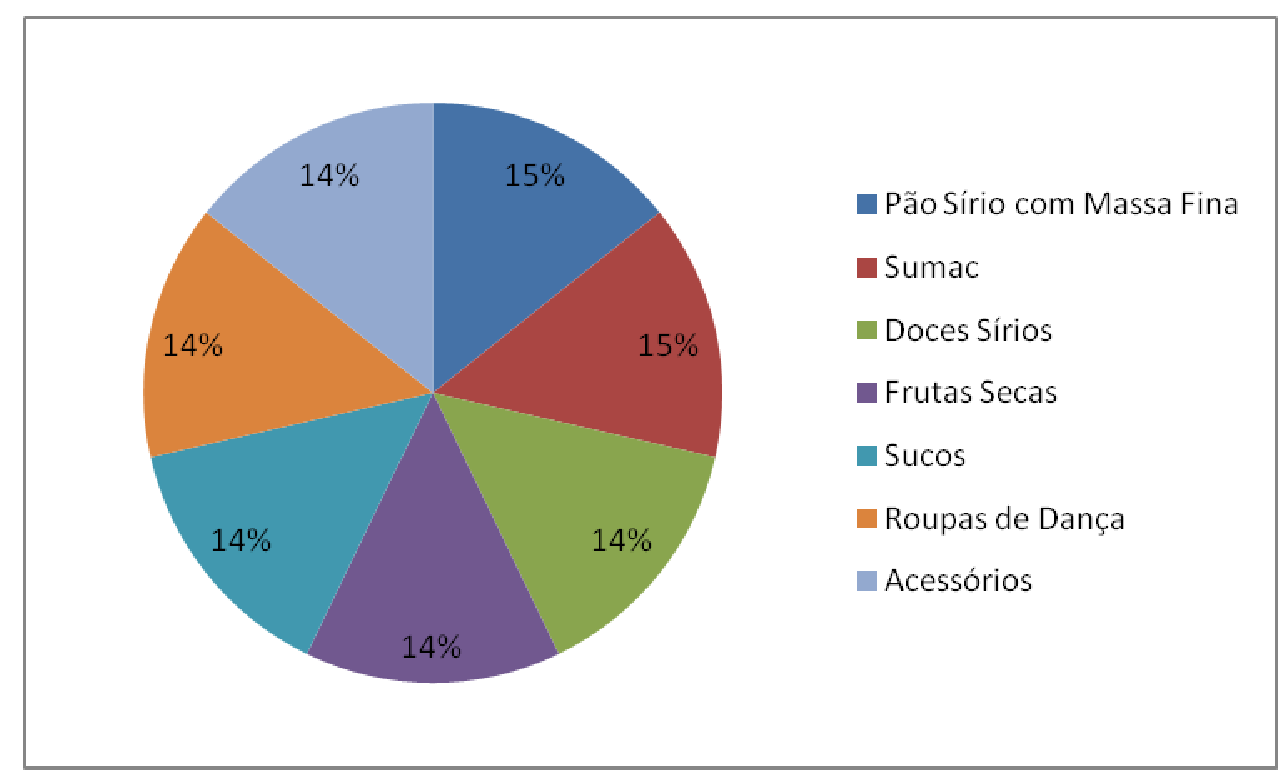

Figura 8: Há algum produto específico que o entrevistado tenha dificuldades para adquirir em Brasília?

Fonte: elaborado pela autora a partir dos dados coletados.

Quando perguntado aos entrevistados se havia algum produto especifico que eles tinham dificuldades para adquirir em Brasília, as respostas encontradas foram: $15 \%$ pão sírio com massa fina, 15\% sumac, 14\% doces sírios, $14 \%$ frutas secas, $14 \%$ sucos, $14 \%$ roupas de dança e $14 \%$ acessórios. 


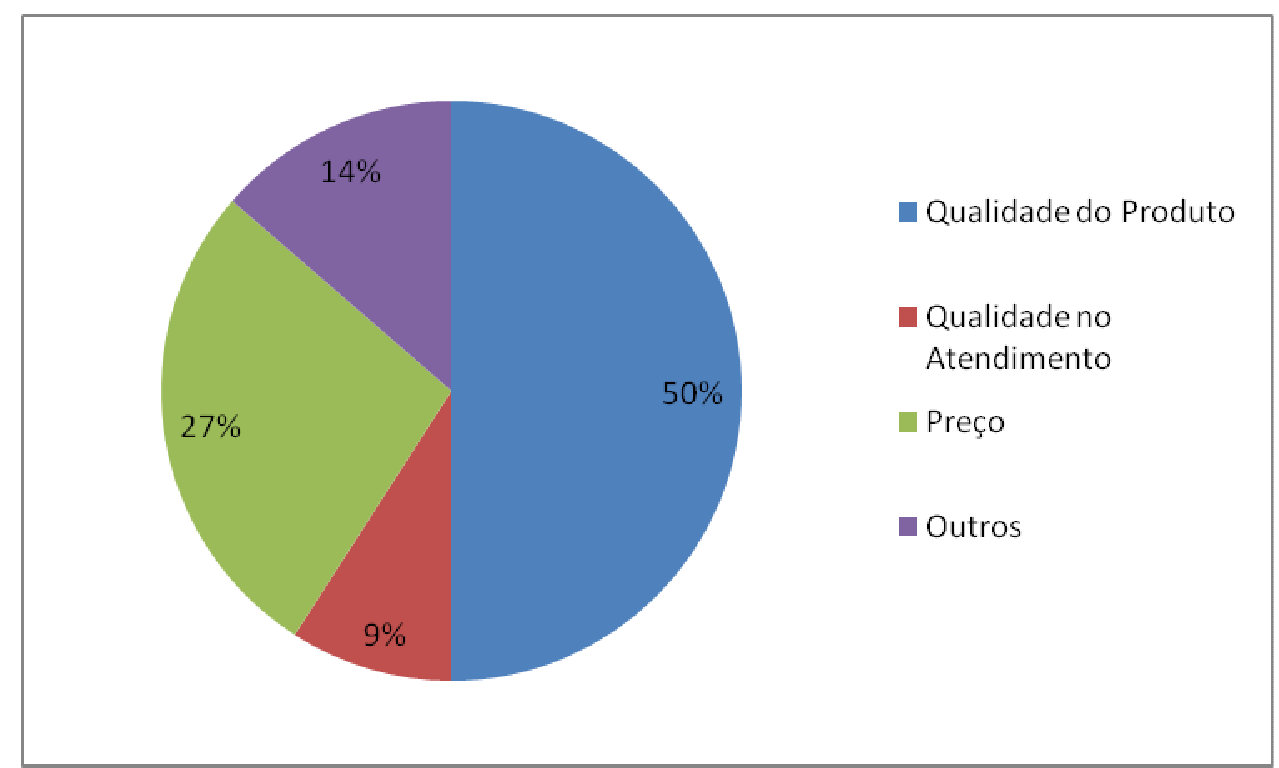

Figura 9: Quais os fatores que influenciaram na escolha de um empório árabe para fazer suas compras?

Fonte: elaborado pela autora a partir dos dados coletados.

Os fatores que influenciaram na escolha de um empório árabe para os entrevistados foram 50\% qualidade do Produto, 27\% preço, 9\% qualidade no atendimento e $14 \%$ tiveram outros fatores que influenciaram no processo de decisão.

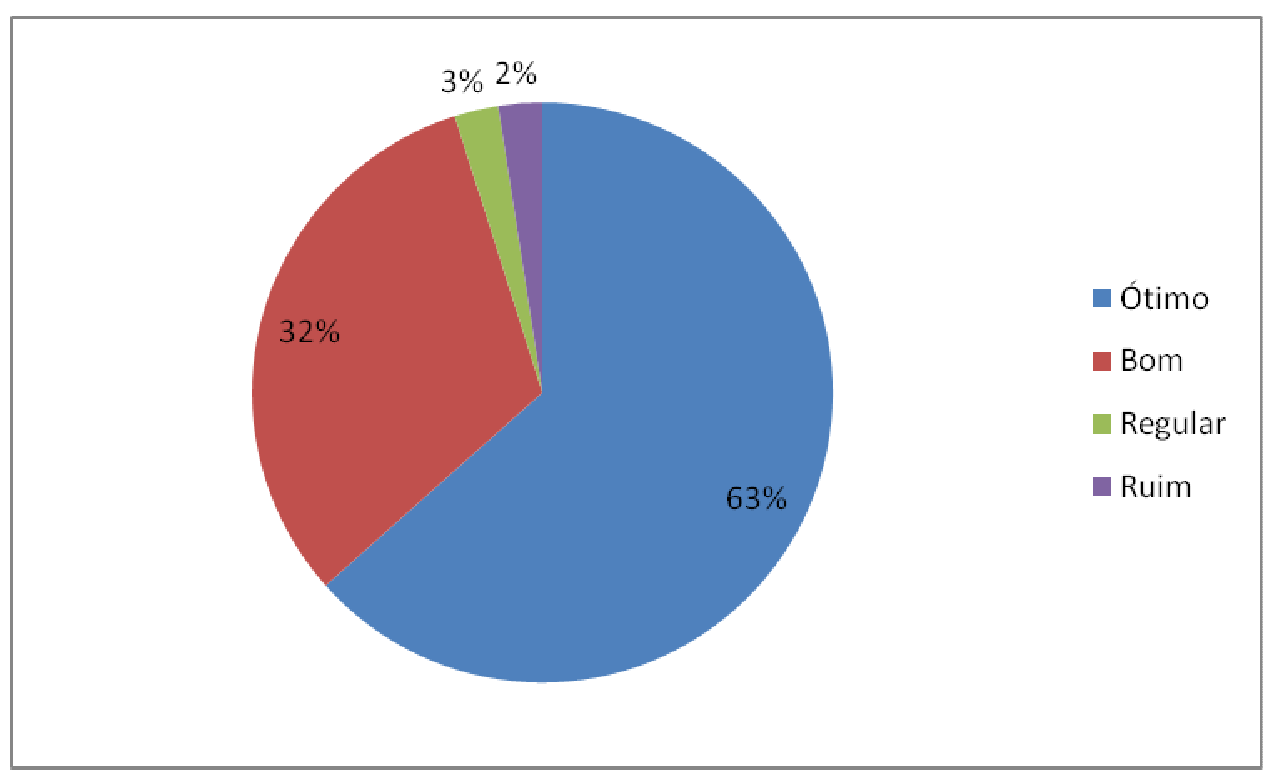

Figura 10: $O$ que o entrevistado acha da abertura de um novo empório árabe na cidade de Brasília?

Fonte: elaborado pela autora a partir dos dados coletados.

Verifica-se que 63\% dos entrevistados acham ótima a idéia da abertura de um novo empório em Brasília, 32\% acreditam que seja bom, 3\% regular e somente $2 \%$ que seja ruim. 


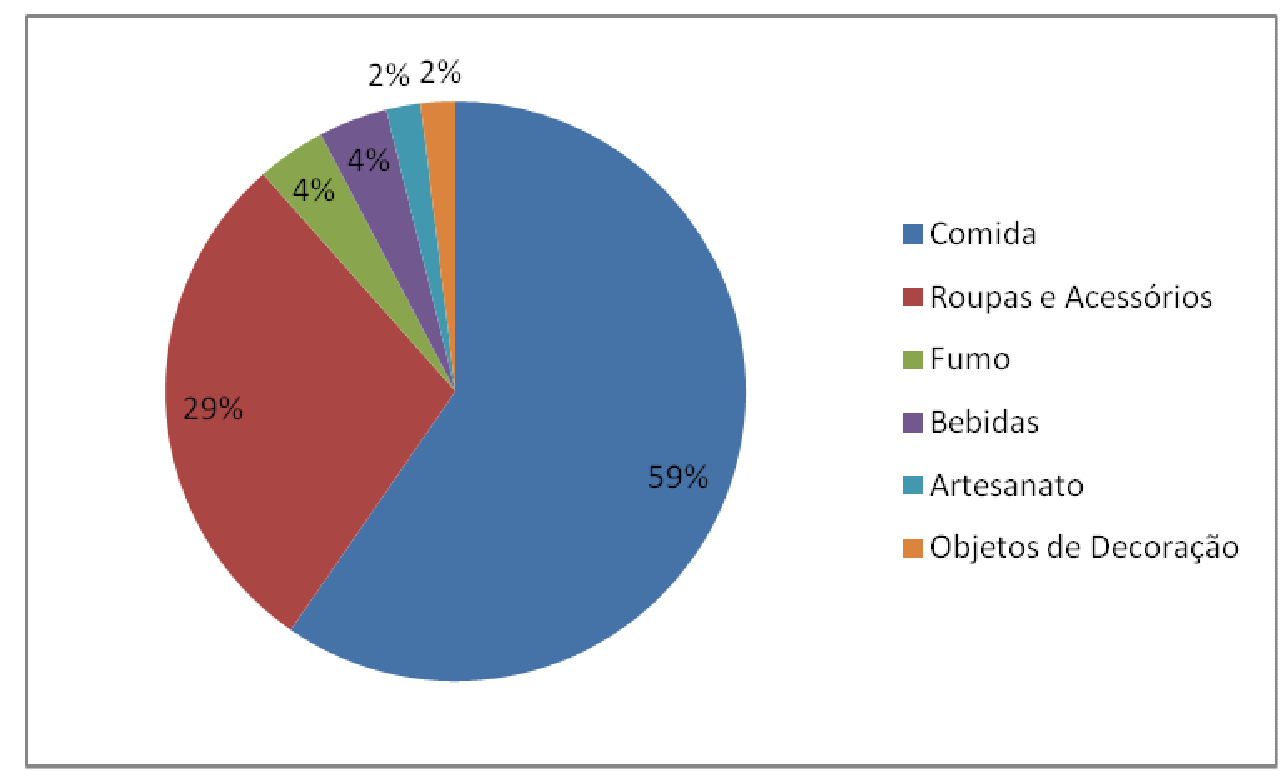

Figura 11: Que tipo de produto árabe atrai mais a atenção do entrevistado? Fonte: elaborado pela autora a partir dos dados coletados.

O produto que mais atrai a atenção dos entrevistados é: 59\% comida, 29\% roupas e acessórios, $4 \%$ fumo, $4 \%$ bebidas, $2 \%$ artesanato e $2 \%$ objetos de decoração.

\subsection{Análise dos resultados do questionário}

Ao analisar os dados advindos da aplicação dos questionários, foi possível perceber que a maioria dos entrevistados não sabia o significado da palavra empório, causando resistência com relação ao negócio. Após esse levantamento, definiu-se que não se utilizaria mais a denominação de empório árabe, e sim "Cantinho árabe Salam Aleikum".

Foram entrevistados moradores do Plano Piloto (Brasília), sendo grande parte solteiros e com nível superior completo. Ao efetuar a pesquisa, constatou-se que $70 \%$ dos entrevistados não sabiam da existência de um empreendimento que fornece produtos árabes, e os 30\% que já fizeram compra em um local que fornece esses produtos foram por indicação de algum conhecido. 
Os fatores que influenciariam na escolha de um local para comprar produtos árabes seriam 50\% qualidade do produto, $27 \%$ preço e $9 \%$ qualidade no atendimento. Após a realização das entrevistas, foi possível perceber que os entrevistados gostam da idéia da abertura de um empreendimento que fornece produtos árabes, sendo que 63\% acharam ótima a abertura e 32\% bom. Constatase, assim, que os potenciais clientes gostam dos produtos árabes, em especial da comida, estão dispostos a comprar produtos árabes, mas nem sempre sabem da existência de um local onde possam encontrar o mesmo. 


\section{PLANO DE NEGÓcIOS}

\section{PLANO DE NEGÓCIOS DO CANTINHO ÁRABE SALAM ALEIKUM}

\section{SUMÁRIO EXECUTIVO}

\section{Objetivo do plano}

Este plano tem como objetivo demonstrar reflexões de questões relacionadas ao período startup, produtos e serviços que serão oferecidos, principais estratégias de marketing, estratégias organizacionais e projeções financeiras do CANTINHO ÁRABE SALAM ALEIKUM, que atuará no comércio varejista.

\section{Oportunidade identificada}

Como principal fator motivador da elaboração deste Plano de Negócio, temos o fato de só existir uma empresa na Asa Sul que oferece produtos árabes, ou seja, o CANTINHO ÁRABE entrará no mercado somente com um concorrente direto, e fará um forte contraponto priorizando os produtos de qualidades, 0 atendimento exclusivo além de um ambiente contextualizado.

Após um período de amadurecimento, em que a empresa atenderá principalmente a clientes que procuram qualidade (produtos/atendimento) e economia, o CANTINHO ÁRABE será referência para quem procura produtos árabes.

\section{Descrição do negócio}

O CANTINHO ÁRABE será um comércio varejista que atuará no segmento de produtos árabes, localizado no Plano Piloto, Asa Sul (Brasília), DF. O negócio terá como sócios majoritários Daiany Georges de Paula Ottoni, graduada em administração em turismo e pós-graduada em gestão de negócios em turismo e Marcelo Barros Ottoni, graduado em engenharia mecatrônica. 


\section{Missão}

"Oferecer ao mercado de Brasília produtos árabes de qualidade e sempre proporcionando um atendimento exemplar."

\section{Visão}

"Em 2010, sermos reconhecidos em Brasília como a melhor opção para aquisição de produtos árabes, conquistando o mercado pela efetividade de nossa atuação."

\section{Fatores críticos de sucesso}

\section{Dinamismo}

Atender clientes com o maior dinamismo possível é de fundamental importância para o negócio. Se objetivo for criar uma nova cultura de consumo ofertando um novo produto, este precisa demonstrar agilidade e também qualificação na hora de vender o produto ao cliente.

\section{Localização}

Tal característica é de extrema relevância ao negócio, pois para escoar o produto passível de consumo de uma forma dinâmica, uma boa localização para empresa é primordial.

\section{Atendimento}

Bem como em diversos outros negócios, é muito válido ter clientes que consumam de forma recorrente de sua empresa. Dessa forma, fidelizar clientes é uma atividade contínua, que demanda esforços diversos, mas vital para o comércio varejista. 


\section{Resumo financeiro}

O investimento inicial necessário será de $R \$$. 22.950,00 O ponto de equilíbrio do empreendimento será atingido no oitavo mês do primeiro ano de operação, quando o fluxo de caixa operacional líquido se tornará positivo. No cenário adotado, o retorno dos recursos investidos será alcançado em um prazo atraente, deixando o caixa liquido positivo, a partir do inicio do segundo ano de atuação. A empresa proposta mostra-se, assim, viável. 


\section{RESUMO DA EMPRESA}

\section{Descrição da forma jurídica}

O CANTINHO ÁRABE optará por ser cadastrada sob forma legal de sociedade limitada, tendo sua sociedade constituída por dois sócios: Daiany Georges de Paula Ottoni idealizadora do projeto, e Marcelo Barros Ottoni, participante ativo na elaboração do mesmo. Daiany Ottoni será detentor de $60 \%$ da empresa, assumindo a direção geral do negócio. Marcelo Ottoni terá $40 \%$ da mesma, assumindo a direção colaborativa do negócio.

A proprietária Daiany Ottoni é graduada em administração em turismo, pela Universidade Católica de Goiás e cursa pós-graduação em Gestão de Negócios em Turismo pela Universidade de Brasília. O proprietário Marcelo Ottoni é graduado em Engenharia Mecatrônica, pela Universidade de Brasília. Ambos possuem histórico junto ao cenário do comércio varejista, e a sócia Daiany Ottoni por ter descendência árabe possui uma vivência com os produtos que serão comercializados.

Devido ao período de estruturação do negócio, bem como para o levantamento de capital inicial para um empreendimento de impacto e sucesso, a abertura da empresa está prevista para janeiro de 2010.

\section{Competências distintas da empresa}

O CANTINHO ÁRABE será uma empresa no ramo do comercio varejista voltado para alimentação, bebidas, vestuário e artigos de decoração, ofertando mercadorias diretamente aos consumidores.

Com a abertura da empresa as pessoas que se interessam por produtos árabes terão onde apreciar e adquirir de forma prática, em horário comercial, todos os produtos que desejarem.

Quanto ao dinamismo da empresa, a mesma deve primar pelo atendimento a seus clientes, tanto no momento da venda quanto no relacionamento pós-venda. 


\section{Sumário startup}

O processo de análise e implantação do projeto do CANTINHO ÁRABE foi planejado em quatro macro etapas, e deverá seguir o cronograma estipulado na tabela a seguir, a partir de julho de 2009.

\begin{tabular}{|l|l|c|}
\hline Etapas & Descrição & Duração \\
\hline Etapa 1 & Revisão do Plano de Negócios & 30 dias \\
\hline Etapa 2 & $\begin{array}{l}\text { Fechamento de aluguel; início do processo de abertura da firma; início das } \\
\text { obras; contratação de funcionários; início do desenvolvimento do material } \\
\text { de comunicação }\end{array}$ & 90 dias \\
\hline Etapa 3 & $\begin{array}{l}\text { Conclusão de obras; compra de matéria inicial; compra e instalação de } \\
\text { maquinário; abertura da firma; início de contato com prospects }\end{array}$ & 45 dias \\
\hline Etapa 4 & Intensificação na comunicação; início das operações & 20 dias \\
\hline
\end{tabular}

\subsection{Localização e facilidades}

A empresa identificou como local para sua melhor instalação na cidade de Brasília, no Distrito Federal, visto que o foco principal da empresa será o público de classe média-alta, descendentes de árabes, e turistas que visitam a cidade de Brasília no período do festival Brasil Sabor em busca da gastronomia oferecida na região.

As instalações estão estimadas em 70 metros quadrados, comportando, portanto, toda a estrutura necessária ao funcionamento da empresa.

O fluxograma do processo para a empresa é bastante simples e, com isso, a organização predial também é básica, sendo necessários: bastante espaço para prateleira e gôndolas para a exposição dos produtos, pouco espaço para estoques, iluminação simples, um escritório bastante simplificado para administração.

Nessas condições, o local escolhido é no Plano Piloto na Asa Sul, e tal sala teria custo de aluguel aproximado de $\mathrm{R} \$ 3 \mathrm{mil} / \mathrm{mês}$. 


\subsection{Planos de expansão}

Baseando-se no interesse de alcançar, em três anos, as metas apontadas na visão da empresa, a fidelização de seus clientes e a fixação da marca, alguns pontos foram estabelecidos para fazer parte do plano de expansão do CANTINHO ÁRABE. São estes planos futuros:

$\checkmark$ Oferecer aos clientes lanches ao final do dia;

$\checkmark$ Criar um ambiente onde os clientes possam fumar Narguile e degustar a comida árabe;

$\checkmark$ Apresentações de bailarinas de dança do ventre.

As datas de implantação de cada item não serão fixadas, já que dependem do desenvolvimento do empreendimento e do aumento de sua carteira de clientes. 
PRODUTOS E SERVIÇOS

\section{1- Descrição dos produtos}

O CATINHO ÁRABE é um comércio varejista que vende produtos árabes do ramo alimento, bebidas, fumo e souvenires.

Os produtos relacionados são os principais produtos consumidos tanto por pessoas árabes como brasileiros. Essa analise foi feita depois da aplicação do questionário com potenciais clientes quando foi perguntado que tipo de produto árabe atrai mais a atenção dos entrevistados, por isso a escolha desses produtos.

O valor de compra dos produtos foi adquirido através de uma pesquisa feita com fornecedores através da internet, e o valor de venda foi obtido através de um calculo médio de $30 \%$ de lucro em cima de cada produto.

A seguir, apresenta-se a descrição dos produtos que estarão sendo inicialmente oferecidos pelo CANTINHO ÁRABE. Os produtos e serviços futuros, porém, necessitam de uma maior estruturação do negócio e um conhecimento mais aprofundado do mercado.

\begin{tabular}{|c|c|c|c|}
\hline FRUTAS SECAS & & VALOR COMPRA & VALOR VENDA \\
\hline AMEIXA C/ CAROÇO & $K G R \$$ & 10,90 & 14,17 \\
\hline AMEIXA S/ CAROÇO & $K G R \$$ & 12,40 & 16,12 \\
\hline BANANA PASSA KG & $K G R \$$ & 9,30 & 12,09 \\
\hline CEREJA AO MARRASQUINO EM CALDA & $K G R \$$ & 22,00 & 28,60 \\
\hline COCO RALADO C/ AÇUCAR & $K G R \$$ & 11,50 & 14,95 \\
\hline COCO RALADO S/ AÇUCAR & $K G R \$$ & 13,90 & 18,07 \\
\hline CUBINHO ( FRUTAS CRISTALIZADAS ) & $K G R \$$ & 3,20 & 4,16 \\
\hline DAMASCO ÁCIDO & $K G R \$$ & 21,90 & 28,47 \\
\hline DAMASCO TURCO DOCE & $K G R \$$ & 17,60 & 22,88 \\
\hline FIGO SECO SOLTO & $K G R \$$ & 19,90 & 25,87 \\
\hline MAÇA SECA & $K G R \$$ & 29,80 & 38,74 \\
\hline MIX DE FRUTAS SECAS (APERITIVO) & $K G R \$$ & 18,90 & 24,57 \\
\hline PASSAS BRANCAS & $K G R \$$ & 12,50 & 16,25 \\
\hline PASSAS PRETAS & $K G R \$$ & 6,60 & 8,58 \\
\hline PERA SECA & $K G R \$$ & 23,00 & 29,90 \\
\hline TAMARA C/ CAROÇO & $K G R \$$ & 11,00 & 14,30 \\
\hline TAMARA S/ CAROÇO & $K G R \$$ & 11,90 & 15,47 \\
\hline CASTANHA - AMENDOIM & & VALOR COMPRA & VALOR VENDA \\
\hline
\end{tabular}




\begin{tabular}{|c|c|c|c|}
\hline AMENDOIM MOIDO & $K G R \$$ & 7,90 & 10,27 \\
\hline AMENDOIM S/ PELE TORR. E SAL. & $K G R \$$ & 9,90 & 12,87 \\
\hline AMENDOIM S/ PELE TORR. S/ SAL & $K G R \$$ & 9,90 & 12,87 \\
\hline AMENDOIM GRAUDO & $K G R \$$ & 7,60 & 9,88 \\
\hline AMENDOIM JAPONES & 500GR & 3,60 & 4,68 \\
\hline AMENDOIM VERMELHO & $\mathrm{KG} \mathrm{R} \$$ & 5,50 & 7,15 \\
\hline CAST CAJU PICADA CRUA OU TORR. & $\mathrm{KG} \mathrm{R} \$$ & 9,90 & 12,87 \\
\hline CASTANHA DE CAJU CRUA & $K G R \$$ & 18,50 & 24,05 \\
\hline CASTANHA DE CAJU TORR. W4TS EXTRA & $K G R \$$ & 19,90 & 25,87 \\
\hline CASTANHA DE CAJU TORR. W3TS & $K G R \$$ & 18,90 & 24,57 \\
\hline CASTANHA DO PARÁ & $K G R \$$ & 18,90 & 24,57 \\
\hline CASTANHA DO PARÁ QUEBR. & $K G R \$$ & 19,90 & 25,87 \\
\hline FARINHA DE CAJU TORRADA (MOIDA) & $K G R \$$ & 4,90 & 6,37 \\
\hline FARINHA DE CAJU (CLARA MOIDA) & $\mathrm{KG} \mathrm{R} \$$ & 5,70 & 7,41 \\
\hline \multicolumn{2}{|l|}{ NOZES - AMENDOAS... } & VALOR COMPRA & VALOR VENDA \\
\hline AMENDOA FATIADA & $K G R \$$ & 33,90 & 44,07 \\
\hline AMENDOA MOIDA & $K G R \$$ & 39,00 & 50,70 \\
\hline AMENDOA S / CASCA & $K G R \$$ & 22,90 & 29,77 \\
\hline AMENDOA S/ PELE & $K G R \$$ & 39,90 & 51,87 \\
\hline AMENDOA TORRADA E SALGADA & $K G R \$$ & 53,80 & 69,94 \\
\hline AVELÃ S/C & $K G R \$$ & 30,90 & 40,17 \\
\hline NOZES MARIPOSA S / C LIGHT & $K G R \$$ & 33,00 & 42,90 \\
\hline NOZES S/ C MARIPOSA EXT LIGHT & $K G R \$$ & 41,90 & 54,47 \\
\hline NOZES S/C NACIONAL INT. (PECAN) & $K G R \$$ & 45,90 & 59,67 \\
\hline PISTACHE CRU & $K G R \$$ & 74,90 & 97,37 \\
\hline PISTACHE TORR. E SALG. & $K G R \$$ & 26,90 & 34,97 \\
\hline \multicolumn{2}{|l|}{ ARTIGOS DE DOCEIRAS } & VALOR COMPRA & VALOR VENDA \\
\hline FONDANT FLEISCHMANN & $K G R \$$ & 6,20 & 8,06 \\
\hline FERMENTO BIOLOGICO 500GR & UN R\$ & 11,90 & 15,47 \\
\hline FERMENTO QUIMICO & $K G R \$$ & 16,90 & 21,97 \\
\hline CX EQUIVALENTE 20 OVOS & UN R\$ & 9,70 & 12,61 \\
\hline CX EQUIVALENTE 30 CLARAS DE OVO & UN R\$ & 9,70 & 12,61 \\
\hline CX EQUIVALENTE 60 GEMAS DE OVO & UN R\$ & 20,90 & 27,17 \\
\hline LEITE DE COCO 1 LTR & UN R\$ & 11,90 & 15,47 \\
\hline LEITE DE COCO VDR $500 \mathrm{ML}$ & UN R\$ & 7,50 & 9,75 \\
\hline COBERTURA SORVETE MORANGO OU CARAMELO & $\mathrm{KG} \mathrm{R} \$$ & 4,00 & 5,20 \\
\hline COBERTURA SORVETE CHOCOLATE & $\mathrm{KG} \mathrm{R} \$$ & 4,50 & 5,85 \\
\hline GLUCOSE 1,5KG & UN R\$ & 7,90 & 10,27 \\
\hline GLICOSE 500 GR & UN R\$ & 3,20 & 4,16 \\
\hline MARSHMALLOW 750GR & UN R\$ & 8,30 & 10,79 \\
\hline EM PÓ $32 \%$ & $K G R \$$ & 6,60 & 8,58 \\
\hline EM PÓ $50 \%$ & $K G R \$$ & 8,90 & 11,57 \\
\hline AÇUCAR IMPALPAVEL & $K G R \$$ & 3,90 & 5,07 \\
\hline AÇUCAR DE CONFEITERO & $K G R \$$ & 3,90 & 5,07 \\
\hline
\end{tabular}




\begin{tabular}{|c|c|c|c|}
\hline DOÇUCAR & $K G R \$$ & 3,10 & 4,03 \\
\hline GLAÇUCAR 500 GR & UN R\$ & 1,50 & 1,95 \\
\hline BAUNILHA CLARA OU ESCURO LITRO & UN R $\$$ & 5,00 & 6,50 \\
\hline CHANTYMIX 1LTR & UN R\$ & 9,90 & 12,87 \\
\hline CHOCO POWER - FLC MICRO PRETO E BRC & $500 \mathrm{GR}$ & 9,30 & 12,09 \\
\hline CHOCO POWER - FLC PEQUENO PRT E BRC & $500 \mathrm{GR}$ & 9,30 & 12,09 \\
\hline DOCE DE LEITE BAG PREDILECTA & $2,5 \mathrm{KG}$ & 15,00 & 19,50 \\
\hline FAVA DE BAUNILHA (FUCHS) & UNI R\$ & 12,60 & 16,38 \\
\hline FLOCOS DE ARROZ - HARALD & $K G R \$$ & 4,60 & 5,98 \\
\hline FONDANT EMULZINT & $K G R \$$ & 7,90 & 10,27 \\
\hline GELATINA NEUTRA PÓ & $K G R \$$ & 31,90 & 41,47 \\
\hline GELEIA DANA (DINAMARCA) & UN R\$ & 12,50 & 16,25 \\
\hline GELEIAS DIET ALEMÃ & UN R\$ & 13,80 & 17,94 \\
\hline GELEIAS PREDILECTA 420 GR LINHA PREMIUM. & $\mathrm{R} \$$ & 6,90 & 8,97 \\
\hline GOIABADA CASCÃO TIA SONIA 500 GR & UN R $\$$ & 3,60 & 4,68 \\
\hline GOIABADA PREDILECTA BLOCO 300 GR & $\mathrm{R} \$$ & 1,30 & 1,69 \\
\hline GOIABADA PREDILECTA CASCÃO 350 GR & $\mathrm{R} \$$ & 1,80 & 2,34 \\
\hline GORDURA VEGETAL HIDROGENADA RECEITA & UN R\$ & 3,60 & 4,68 \\
\hline FIGO EM CALDA PREDILECTA LT 400 GR & UN R\$ & 3,50 & 4,55 \\
\hline KARO PET $360 \mathrm{GR}$ & $K G R \$$ & 5,50 & 7,15 \\
\hline MARGARINA GRADINA FOLEADA & $K G R \$$ & 10,45 & 13,59 \\
\hline MEL PURO (NATUCENTRO) 470GR & UN R\$ & 6,25 & 8,13 \\
\hline MELADO (FIOS DE OURO) $380 \mathrm{~g}$ PT DE BARRO & UN R\$ & 4,90 & 6,37 \\
\hline MELADO (FIOS DE OURO) $900 \mathrm{GRs}$ & UN R $\$$ & 6,80 & 8,84 \\
\hline MISSANGA COLORIDA OU VERMELHA MIL CORES 500 GR & UN R $\$$ & 17,00 & 22,10 \\
\hline PESSEGO EM CALDA LT 440 GR & UN R\$ & 4,90 & 6,37 \\
\hline SACO JUJUBA kuky 500GR & UN R\$ & 2,40 & 3,12 \\
\hline SOFT BRILHO 200GR & UN R $\$$ & 2,70 & 3,51 \\
\hline ARROZ & & VALOR COMPRA & VALOR VENDA \\
\hline ARROZ 7 CEREAIS (RARIS) & $500 \mathrm{gr} R \$$ & 6,60 & 8,58 \\
\hline ARROZ ARBORIO (BLUE VILLE - RISOTO) & $K G R \$$ & 6,80 & 8,84 \\
\hline ARROZ ARBORIO (TIO JOÃO - RISOTO) & $K G R \$$ & 8,90 & 11,57 \\
\hline ARROZ INT. AGULINHA BRANCO OU VERMELHO & $K G R \$$ & 2,80 & 3,64 \\
\hline ARROZ JAPONÊS GUIN & $K G R \$$ & 6,40 & 8,32 \\
\hline ARROZ PRETO (RUZENE) & $K G R \$$ & 23,90 & 31,07 \\
\hline BRANCO OU PARBOLIZADO - BLUE VILLE & $K G R \$$ & 3,00 & 3,90 \\
\hline INTEGRAL CATETO BRANCO OU VERMELHO & $K G R \$$ & 4,60 & 5,98 \\
\hline SELVAGEM (BLUE VILLE) & $K G R \$$ & 69,00 & 89,70 \\
\hline SELVAGEM (BLUE VILLE) & 200GR & 13,90 & 18,07 \\
\hline TEMPEROS & & VALOR COMPRA & VALOR VENDA \\
\hline AÇAFRÃO & $K G R \$$ & 7,20 & 9,36 \\
\hline AÇAFRÃO ESPANHOL (LA LIDIA) & $K G R \$$ & 59,90 & 77,87 \\
\hline AJI-NO-MOTO & $K G R \$$ & 16,30 & 21,19 \\
\hline ALECRIM FLOCOS - MARROCOS & $K G R \$$ & 12,50 & 16,25 \\
\hline
\end{tabular}




\begin{tabular}{|c|c|c|c|}
\hline ALHO DESIDRATADO FLOCOS & $K G R \$$ & 6,50 & 8,45 \\
\hline ALHO DESIDRATADO EM PO & $K G R \$$ & 4,60 & 5,98 \\
\hline ALHO GRANULADO & $K G R \$$ & 6,90 & 8,97 \\
\hline AMACIANTE DE CARNE (NESTLE) & $K G R \$$ & 9,90 & 12,87 \\
\hline ANETO (ENDRO DILL) & $K G R \$$ & 18,50 & 24,05 \\
\hline ANIZ ESTRELADO & $K G R \$$ & 15,00 & 19,50 \\
\hline BETERRABA EM PÓ & $K G R \$$ & 28,00 & 36,40 \\
\hline BICARBONATO DE SODIO & $K G R \$$ & 4,00 & 5,20 \\
\hline CALDO DE FONDOR - MAGGI - NESTLE & $K G R \$$ & 14,50 & 18,85 \\
\hline CALDO DE GALINA E CARNE - MAGGI - NESTLE & $K G R \$$ & 9,50 & 12,35 \\
\hline CANELA EM PÓ & $K G R \$$ & 6,90 & 8,97 \\
\hline CANELA EM PAU 45CM & $K G R \$$ & 11,40 & 14,82 \\
\hline CANELA EM PAU SELE. $6 \mathrm{CM}$ & $K G R \$$ & 8,20 & 10,66 \\
\hline CARDAMONO EM PÓ OU GRÃO & $K G R \$$ & 96,00 & 124,80 \\
\hline CEBOLA EM FLOCOS & $K G R \$$ & 11,50 & 14,95 \\
\hline CEBOLA EM PÓ & $K G R \$$ & 9,70 & 12,61 \\
\hline CHILLY EM PÓ & $K G R \$$ & 23,50 & 30,55 \\
\hline CHIMI - CHURRI & $K G R \$$ & 26,00 & 33,80 \\
\hline COENTRO EM GRÃO & $K G R \$$ & 7,30 & 9,49 \\
\hline COENTRO EM PÓ & $K G R \$$ & 12,50 & 16,25 \\
\hline COGOMELO SECO (FUNGUI SECCHI CHILENO) & $K G R \$$ & 58,90 & 76,57 \\
\hline COGUMELO SHITAKE & $K G R \$$ & 61,90 & 80,47 \\
\hline COLORAL & $K G R \$$ & 3,00 & 3,90 \\
\hline COMINHO EM GRÃO & $K G R \$$ & 14,90 & 19,37 \\
\hline COMINHO EM PÓ ESPECIAL & $K G R \$$ & 13,90 & 18,07 \\
\hline CRAVO EM FLOR & $K G R \$$ & 14,90 & 19,37 \\
\hline CRAVO EM PÓ & $K G R \$$ & 11,90 & 15,47 \\
\hline CURRY IMPORTADO & $K G R \$$ & 19,90 & 25,87 \\
\hline CURRY NACIONAL & $K G R \$$ & 10,00 & 13,00 \\
\hline ERVAS DE PROVENCE & $K G R \$$ & 25,90 & 33,67 \\
\hline ERVAS FINA & $K G R \$$ & 27,90 & 36,27 \\
\hline ESTRAGÃO & $K G R \$$ & 86,90 & 112,97 \\
\hline GENGIBRE EM PÓ & $K G R \$$ & 12,00 & 15,60 \\
\hline HORTELÃ SECA TRITURADA & $K G R \$$ & 7,90 & 10,27 \\
\hline KUMMEL & $K G R \$$ & 21,90 & 28,47 \\
\hline LIMÃO E ERVAS & $K G R \$$ & 23,50 & 30,55 \\
\hline LOURO EM FOLHA & $K G R \$$ & 16,50 & 21,45 \\
\hline LOURO EM PÓ & $K G R \$$ & 12,00 & 15,60 \\
\hline MANJERICÃO (CHILENO) & $K G R \$$ & 9,90 & 12,87 \\
\hline MANJERONA (EGIPICIA) & $K G R \$$ & 15,50 & 20,15 \\
\hline MENTA SECA DESIDRATADA & $K G R \$$ & 12,50 & 16,25 \\
\hline MOSTARDA EM GRÃO & $K G R \$$ & 12,20 & 15,86 \\
\hline MOSTARDA EM PÓ & $K G R \$$ & 11,50 & 14,95 \\
\hline NÓZ MOSCADA EM PÓ PURA OU EM BOLA & $K G R \$$ & 39,90 & 51,87 \\
\hline
\end{tabular}




\begin{tabular}{|c|c|c|c|}
\hline OREGANO EXTRA (CHILENO) & $K G R \$$ & 11,90 & 15,47 \\
\hline PAPRICA DOCE OU PICANTE & $K G R \$$ & 12,50 & 16,25 \\
\hline PIMENTA CALABRESA INDIANA & $K G R \$$ & 19,90 & 25,87 \\
\hline PIMENTA BRANCA GRÃO & $K G R \$$ & 19,90 & 25,87 \\
\hline PÍMENTA DO REINO GRÃO & $K G R \$$ & 9,20 & 11,96 \\
\hline PIMENTA DOCE GRÃO & $K G R \$$ & 12,50 & 16,25 \\
\hline PIMENTA ROSA & $K G R \$$ & 33,90 & 44,07 \\
\hline PIMENTA VERDE (FUCHS) & $K G R \$$ & 25,90 & 33,67 \\
\hline RAIZ FORTE & $K G R \$$ & 69,90 & 90,87 \\
\hline SAL DE LIMÃO & $K G R \$$ & 11,90 & 15,47 \\
\hline SAL GROSSO & $K G R \$$ & 1,60 & 2,08 \\
\hline SALSA DESIDRATADA & $K G R \$$ & 12,10 & 15,73 \\
\hline TEMPERO SIRIO & $K G R \$$ & 33,00 & 42,90 \\
\hline TEMPERO MISTO & $K G R \$$ & 20,00 & 26,00 \\
\hline TEMPERO P/ CHURRASCO & $K G R \$$ & 7,90 & 10,27 \\
\hline TOMATE SECO DESI. VERMELHO & $K G R \$$ & 18,50 & 24,05 \\
\hline TOMILHO & $K G R \$$ & 19,80 & 25,74 \\
\hline ZATAR & $K G R \$$ & 12,40 & 16,12 \\
\hline ZIMBRO & $K G R \$$ & 33,00 & 42,90 \\
\hline PRODUTOS NATURAIS & & VALOR COMPRA & VALOR VENDA \\
\hline AÇUCAR MASCAVO & $K G R \$$ & 2,60 & 3,38 \\
\hline AMIDO DE MILHO & $K G R \$$ & 1,90 & 2,47 \\
\hline AVEIA - FERLA (FINA OU GROSSA) & $K G R \$$ & 3,30 & 4,29 \\
\hline AVEIA EM GRÃO & $K G R \$$ & 2,00 & 2,60 \\
\hline CACHE (TRIGO SARRACENO) & $K G R \$$ & 8,60 & 11,18 \\
\hline CANJICA BRANCA & $K G R \$$ & 1,90 & 2,47 \\
\hline CEVADINHA & $K G R \$$ & 2,80 & 3,64 \\
\hline COUSCOUS MARROQUINO & $K G R \$$ & 16,90 & 21,97 \\
\hline COUSCOUS MARROQUINO FERRERO CX & 500GR & 11,50 & 14,95 \\
\hline ERVILHA PARTIDA & $K G R \$$ & 3,60 & 4,68 \\
\hline FARELO DE TRIGO & $K G R \$$ & 2,60 & 3,38 \\
\hline FARINHA DE TRIGO INTEGRAL & $K G R \$$ & 2,60 & 3,38 \\
\hline FUBA & $K G R \$$ & 1,50 & 1,95 \\
\hline GERGILIM BRANCO & $K G R \$$ & 12,90 & 16,77 \\
\hline GERGILIM BRANCO TORR. & $K G R \$$ & 10,60 & 13,78 \\
\hline GERGILIM C/C & $K G R \$$ & 11,90 & 15,47 \\
\hline GERGILIM PRETO & $K G R \$$ & 10,90 & 14,17 \\
\hline GERMEN DE TROGO & $K G R \$$ & 4,30 & 5,59 \\
\hline GRANOLA - CEREAL CROCANTE & $K G R \$$ & 6,60 & 8,58 \\
\hline GRÃO DE BICO & $K G R \$$ & 4,20 & 5,46 \\
\hline GUARANA EM PÓ & $K G R \$$ & 37,90 & 49,27 \\
\hline LENTILHA & $K G R \$$ & 5,50 & 7,15 \\
\hline LENTILHA VERMELHA LIBANO & $K G R \$$ & 20,90 & 27,17 \\
\hline MILHO DE PIPOCA & $K G R \$$ & 3,20 & 4,16 \\
\hline
\end{tabular}




\begin{tabular}{|c|c|c|c|}
\hline POLVILHO AZEDO & $K G R \$$ & 1,90 & 2,47 \\
\hline POLVILHO DOCE & $K G R \$$ & 2,50 & 3,25 \\
\hline PROTEINA DE SOJA - OLVEBRA & $K G R \$$ & 4,30 & 5,59 \\
\hline QUINOA REAL EM GRÃO & $K G R \$$ & 30,00 & 39,00 \\
\hline QUINOA REAL VERMELHA, PRETA OU MISTA EM GRÃO & $K G R \$$ & 33,00 & 42,90 \\
\hline SEMENTE DE LINHACA & $K G R \$$ & 4,50 & 5,85 \\
\hline SEMOLINA & $K G R \$$ & 4,50 & 5,85 \\
\hline TAPIOCA & $K G R \$$ & 2,80 & 3,64 \\
\hline TRIGO EM GRÃO & $K G R \$$ & 1,65 & 2,15 \\
\hline TRIGO FINO NACIONAL - MARROCOS & $K G R \$$ & 2,10 & 2,73 \\
\hline TRIGO IMPORTADO LIBANO & $K G R \$$ & 11,00 & 14,30 \\
\hline CHOCOLATE & & VALOR COMPRA & VALOR VENDA \\
\hline AO LEITE & $K G R \$$ & 19,90 & 25,87 \\
\hline BRANCO & $K G R \$$ & 21,90 & 28,47 \\
\hline MEIO AMARGO & $K G R \$$ & 19,90 & 25,87 \\
\hline HIDROGENADO AO LEITE & $K G R \$$ & 12,90 & 16,77 \\
\hline DIET 500 GR & UN R\$ & 21,90 & 28,47 \\
\hline LEITE CONDENSADO 2,60KG & UN R\$ & 20,90 & 27,17 \\
\hline NESTLE EM PÓ & $K G R \$$ & 12,90 & 16,77 \\
\hline AO LEITE & $K G R \$$ & 22,90 & 29,77 \\
\hline BRANCO & $K G R \$$ & 24,50 & 31,85 \\
\hline MEIO AMARGO & $K G R \$$ & 21,50 & 27,95 \\
\hline AO LEITE & $K G R \$$ & 10,90 & 14,17 \\
\hline MEO AMARGO & $K G R \$$ & 11,60 & 15,08 \\
\hline BRANCO & $K G R \$$ & 12,90 & 16,77 \\
\hline GOTAS AMARGO & $K G R \$$ & 10,90 & 14,17 \\
\hline GRANULADO CONFEITERO & $K G R \$$ & 4,90 & 6,37 \\
\hline MELKEN AMARGO & $K G R \$$ & 14,90 & 19,37 \\
\hline MELKEN BRANCO & $K G R \$$ & 19,90 & 25,87 \\
\hline TOP AO LEITE & $K G R \$$ & 11,90 & 15,47 \\
\hline TOP BRANCO & $K G R \$$ & 13,40 & 17,42 \\
\hline TOP MEIO AMARGO & $K G R \$$ & 11,90 & 15,47 \\
\hline CACAU EM PÓ & $K G R \$$ & 11,90 & 15,47 \\
\hline M ANTEIGA DE CACAU & KG R\$ & 25,00 & 32,50 \\
\hline MOLHOS & & VALOR COMPRA & VALOR VENDA \\
\hline ALHO & $150 \mathrm{ml}$ & 2,20 & 2,86 \\
\hline INGLES & $150 \mathrm{ml}$ & 2,20 & 2,86 \\
\hline LIMÃO & $150 \mathrm{ml}$ & 2,20 & 2,86 \\
\hline PIMENTA ARABE & $150 \mathrm{ml}$ & 2,20 & 2,86 \\
\hline PIMENTA VERMELHA & $150 \mathrm{ml}$ & 2,20 & 2,86 \\
\hline ALHO & Itr & 7,90 & 10,27 \\
\hline INGLES & Itr & 5,50 & 7,15 \\
\hline PIMENTA & Itr & 6,50 & 8,45 \\
\hline SOJA (SHOYU) & Itr & 7,90 & 10,27 \\
\hline
\end{tabular}




\begin{tabular}{|c|c|c|c|}
\hline ALHO, INGLES, PIMENTA, SOJA & $150 \mathrm{ML}$ & 2,20 & 2,86 \\
\hline MOLHO DE SOJA (SHOYU) & Itr & 7,80 & 10,14 \\
\hline LIGHT MOLHO DE SOJA (SHOYU) & Itr & 9,90 & 12,87 \\
\hline LIGHT MOLHO DE SOJA (SHOYU) & $500 \mathrm{ml}$ & 9,90 & 12,87 \\
\hline INGLES & $960 \mathrm{ml}$ & 3,60 & 4,68 \\
\hline SOJA (SHOYU) & $960 \mathrm{ml}$ & 3,60 & 4,68 \\
\hline ACETO BALSAMICO MARCOL (DI MODENA) IMP. ITA & $500 \mathrm{ml}$ & 10,90 & 14,17 \\
\hline AZEITE DENDE (PALMA) LTR & UN R\$ & 11,90 & 15,47 \\
\hline MOSTARDA DIJON - GRAND DOR - FRANÇA & $360 \mathrm{GR}$ & 10,50 & 13,65 \\
\hline MOSTARDA DIJON C/ GRÃOS - GRAND DOR - FRANÇA & $360 \mathrm{GR}$ & 10,50 & 13,65 \\
\hline OLEO DE GERGILIM CRU E TORRADO & $150 \mathrm{ML}$ & 8,30 & 10,79 \\
\hline OLEO DE GERGILIM CRU E TORRADO & $900 \mathrm{ml}$ & 28,90 & 37,57 \\
\hline TABASCO VERMELHO OU VERDE $60 \mathrm{ML}$ & UN R\$ & 8,20 & 10,66 \\
\hline TAHINE ISTAMBUL BALDE FECHADO DE 13 KG & $K G R \$$ & 17,90 & 23,27 \\
\hline TAHINE ISTAMBUL KG & $K G R \$$ & 18,90 & 24,57 \\
\hline TAHINE ISTAMBUL LT $500 \mathrm{ML}$ & UN R\$ & 14,90 & 19,37 \\
\hline VINAGRE ROSSONI (cinco TIPOS) & $500 \mathrm{ml}$ & 2,00 & 2,60 \\
\hline MANTEGA DE GARRAFA SERTANORTE $500 \mathrm{ML}$ & UN R\$ & 6,60 & 8,58 \\
\hline MANTEGA DE GARRAFA SERTANORTE $900 \mathrm{ML}$ & UN R\$ & 13,30 & 17,29 \\
\hline PREDILECTA & & VALOR COMPRA & VALOR VENDA \\
\hline CATCHUP GALÃO 3,6 KG & $\mathrm{R} \$$ & 10,90 & 14,17 \\
\hline MOSTARDA GALÃO 3,3 KG & $R \$$ & 10,90 & 14,17 \\
\hline MOSTARDA E CATCHUP SACHET & $\mathrm{R} \$$ & 9,90 & 12,87 \\
\hline ESTRATO DE TOMATE BAG $4.1 \mathrm{KG}$ & $R \$$ & 14,40 & 18,72 \\
\hline MANGO CHUTNEY 400 GR LINHA PREMIUM. & $\mathrm{R} \$$ & 6,90 & 8,97 \\
\hline MOLHO 150 ML (INGLÊS - SHOYU - ALHO - PIMENTA) & $\mathrm{R} \$$ & 2,60 & 3,38 \\
\hline AZEITE & & VALOR COMPRA & VALOR VENDA \\
\hline MOLINOS - ARGENTINOPURO - LT & $500 \mathrm{ml}$ & 7,90 & 10,27 \\
\hline TORRE DE QUINTELA -PORTUGUES EXTRA VIRGEM -VDR & $500 \mathrm{ml}$ & 10,90 & 14,17 \\
\hline OLIVENZA - ESPANHOL EXTRA VIRGEM - VDR & $500 \mathrm{ml}$ & 10,90 & 14,17 \\
\hline CONSERVAS & & VALOR COMPRA & VALOR VENDA \\
\hline ALCAPARRA & $K G R \$$ & 12,90 & 16,77 \\
\hline ALITE RIBAMAR & $K G R \$$ & 25,50 & 33,15 \\
\hline ASPARGO VDR 205 GR & UN R\$ & 9,60 & 12,48 \\
\hline CHAMPIGNOM EM CONSERVA & $K G R \$$ & 19,80 & 25,74 \\
\hline CORAÇÃO DE ALCACHOFRA VDR 165 GR & UN R\$ & 5,30 & 6,89 \\
\hline FOLHA DE UVA & $K G R \$$ & 18,90 & 24,57 \\
\hline FUNDO DE ALCACHOFRA LT 1,5 KG & UN R\$ & 32,90 & 42,77 \\
\hline FUNDO DE ALCACHOFRA VDR 980 GR & UN R\$ & 23,90 & 31,07 \\
\hline PALMITO DE AÇAI (SABOR) LT 500 GR & UN R\$ & 11,90 & 15,47 \\
\hline TOMATE SECO EM CONSERVA VDR 1,5 KG & UN R\$ & 24,50 & 31,85 \\
\hline AZEITONAS & & VALOR COMPRA & VALOR VENDA \\
\hline CHILENA A VAREJO & $K G R \$$ & 14,90 & 19,37 \\
\hline CHILENA BALDE $2 \mathrm{KG}$ & $K G R \$$ & 17,90 & 23,27 \\
\hline
\end{tabular}




\begin{tabular}{|c|c|c|c|}
\hline GREGA & $K G R \$$ & 24,90 & 32,37 \\
\hline PORTUGUESA & $K G R \$$ & 13,00 & 16,90 \\
\hline PRETA SEM / CAROÇO OU FATIADA & $K G R \$$ & 14,90 & 19,37 \\
\hline VERDE C/ CAROÇO A VAREJO & $K G R \$$ & 13,90 & 18,07 \\
\hline VERDE C/ CAROÇO BALDE 2 KG & $K G R \$$ & 8,90 & 11,57 \\
\hline VERDE FATIADA OU SEM CAROÇO BALDE 2 KG & $K G R \$$ & 12,90 & 16,77 \\
\hline ARTIGOS ÀRABES & & VALOR COMPRA & VALOR VENDA \\
\hline AGUA DE FLOR DE ROSA E LARANJA ZENNY & $360 \mathrm{ML}$ & 15,90 & 20,67 \\
\hline AMENDOIM GRAUDO TORR. SALG. & 500GR & 6,30 & 8,19 \\
\hline ARAK - LIBANO - KASSLIK & $350 \mathrm{ML}$ & 30,00 & 39,00 \\
\hline ARAK GEORGE AUBERT & $900 \mathrm{ML}$ & 23,00 & 29,90 \\
\hline CONCENTRADO DE ROMÃ & $260 \mathrm{ML}$ & 20,90 & 27,17 \\
\hline PISTACHE TORR. SALG. & 500GR & 35,00 & 45,50 \\
\hline RAHAT ISTAMBUL & $K G R \$$ & 7,60 & 9,88 \\
\hline SNAUBA & $K G R \$$ & 106,00 & 137,80 \\
\hline SOJA TORR. SALG. C/ SABORES & 500GR & 5,90 & 7,67 \\
\hline FEIJÕES & & VALOR COMPRA & VALOR VENDA \\
\hline AZUKI & $K G R \$$ & 5,90 & 7,67 \\
\hline BRANCO & $K G R \$$ & 4,50 & 5,85 \\
\hline FAVA CHILENA & $K G R \$$ & 7,90 & 10,27 \\
\hline FRADÃO & $K G R \$$ & 4,50 & 5,85 \\
\hline FRADINHO & $K G R \$$ & 2,90 & 3,77 \\
\hline MANTEIGA & $K G R \$$ & 6,90 & 8,97 \\
\hline MULATINHO & $K G R \$$ & 5,80 & 7,54 \\
\hline ROXINHO & $K G R \$$ & 10,40 & 13,52 \\
\hline SOJA EM GRÃO & $K G R \$$ & 2,30 & 2,99 \\
\hline VERMELHO & $K G R \$$ & 8,70 & 11,31 \\
\hline SOUVENIERS & & VALOR COMPRA & VALOR VENDA \\
\hline IINCENSÁRIO DE RESINA & UN R $\$$ & 3,90 & 5,07 \\
\hline INCENSO & UN R $\$$ & 1,50 & 1,95 \\
\hline MASBAHA DECORATIVA - TIPO CRISTAL & UN R $\$$ & 19,90 & 25,87 \\
\hline RELÓGIO EM FORMA DE MESQUITA & UN R $\$$ & 35,00 & 45,50 \\
\hline CAIXA DE MOSAICO MARCHETADO COM MADRE-PÉROLA & UN R $\$$ & 39,90 & 51,87 \\
\hline CAIXA DE MOSAICO MARCHETADO COM MADRE-PÉROLA OCTAVA & UN R\$ & 39,90 & 51,87 \\
\hline CAMISETA JERUSALÉM & UN R\$ & 15,00 & 19,50 \\
\hline CARTÃO BOAS FESTAS & UN R $\$$ & 2,99 & 3,89 \\
\hline CD NOBRE ALCORÃO & UN R\$ & 9,90 & 12,87 \\
\hline COHEL PÓ PARA PINTAR OS OLHOS (Kajal) & UN R\$ & 12,00 & 15,60 \\
\hline DELINEADOR COHEL EM BASTÃO (KAJAL) & UN R $\$$ & 19,90 & 25,87 \\
\hline ESCOVA DE DENTE NATURAL (SIWAK) & UN R\$ & 14,50 & 18,85 \\
\hline PITEIRAS DESCARTAVEIS PARA NARGUILE & UN R $\$$ & 5,90 & 7,67 \\
\hline PEGADOR DE CARVÃO & UN R\$ & 9,90 & 12,87 \\
\hline ALUMINIO ESPECIAL PARA NARGUILE & UN R\$ & 9,90 & 12,87 \\
\hline BASE DE VIDRO PARA NARGUILE COMPACTO & UN R\$ & 19,90 & 25,87 \\
\hline
\end{tabular}




\begin{tabular}{|c|c|c|c|}
\hline BASE DE VIDRO BÁSICO PARA NARGUILE & UN R\$ & 29,40 & 38,22 \\
\hline BASE DE VIDRO DE ROSCA MODELO JUMBO & UN R $\$$ & 65,00 & 84,50 \\
\hline BASE DE CRISTAL PARA NARGUILE MÉDIO & UN R\$ & 139,00 & 180,70 \\
\hline MANGUEIRA DE COURO PARA NARGUILE PEQUENO & UN R $\$$ & 9,90 & 12,87 \\
\hline MANGUEIRA DE COURO PARA NARGUILE LONGA & UN R\$ & 15,90 & 20,67 \\
\hline MANGUEIRA DE COURO LONGA ROSQUEÁVEL & UN R $\$$ & 49,00 & 63,70 \\
\hline CINZEIRO PARA NARGUILE MINI & UN R\$ & 3,00 & 3,90 \\
\hline BASE CENTRAL CROMADA COM DETALHES ENTALHADOS & UN R $\$$ & 35,00 & 45,50 \\
\hline SUPORTE DA MANGUEIRA COM ROSCA MACHO & UN R $\$$ & 3,90 & 5,07 \\
\hline SUPORTE DE QUEIMADOR PARA NARGUILE & UN R $\$$ & 3,90 & 5,07 \\
\hline VÁLVULA DE AR PARA NARGUILE & UN R $\$$ & 3,90 & 5,07 \\
\hline RECIPIENTE PARA TABACO DE BARRO & UN R $\$$ & 12,00 & 15,60 \\
\hline RECIPIENTE PARA TABACO DE PORCELANA & UN R $\$$ & 12,00 & 15,60 \\
\hline RECIPIENTE PARA TABACO DE PORCELANA PEQUENO & UN R\$ & 5,50 & 7,15 \\
\hline NARGUILE DE ALTO PADRÃO COM BASE ACRÍLICO DA GRIFE MYA & UN R $\$$ & 200,00 & 260,00 \\
\hline $\begin{array}{l}\text { NARGUILE DE ALTO PADRÃO COM BASE DE CRISTAL DA GRIFE } \\
\text { MYA }\end{array}$ & UN R $\$$ & 469,99 & 610,99 \\
\hline NARGUILE MYA COM 4 SAÍDAS, VÁLVULAS INTELIGENTES & UN R $\$$ & 790,00 & 1027,00 \\
\hline NARGUILE COMPACTO CROMADO COM DUAS SAÍDAS (MINI) & UN R $\$$ & 79,90 & 103,87 \\
\hline NARGUILE CROMADO COM DUAS SAÍDAS (MÉDIO) & UN R\$ & 139,90 & 181,87 \\
\hline NARGUILE CROMADO DUAS SAÍDAS NA MALETA (INTERMEDIÁRIO) & UN R $\$$ & 169,90 & 220,87 \\
\hline NARGUILE DE BRONZE COM CRISTAL E RELÓGIO (GRANDE) & UN R\$ & 350,00 & 455,00 \\
\hline NARGUILE DOURADO COM CRISTAL (MÉDIO) & UN R $\$$ & 299,00 & 388,70 \\
\hline NARGUILE DE MÃO TIPO CACHIMBO & UN R\$ & 39,90 & 51,87 \\
\hline NARGUILE COMPACTO DOURADO (MINI) & UN R $\$$ & 54,90 & 71,37 \\
\hline ESSÊNCIA AROMATIZADA/TAMBAC CAIXA COM $50 \mathrm{~g}$ & UN R $\$$ & 3,90 & 5,07 \\
\hline TAMBAC MARCA AL FAKHER & UN R $\$$ & 6,90 & 8,97 \\
\hline TAMBAC MARCA PRINCE & UN R $\$$ & 3,90 & 5,07 \\
\hline MAÇARICO PORTÁTIL PARA ACENDER CARVÃO & UN R $\$$ & 19,90 & 25,87 \\
\hline PAPIRO COM GRAVURAS FARAÔNICAS & UN R $\$$ & 15,00 & 19,50 \\
\hline TELA COM VERSÍCULOS DO ALCORÃO & UN R $\$$ & 39,90 & 51,87 \\
\hline TAPETES PARA ORAÇÃO COM EFEITO, 3D & UN R $\$$ & 59,90 & 77,87 \\
\hline TERÇO ISLÂMICO - MASBAHA & UN R $\$$ & 15,00 & 19,50 \\
\hline XALE PALESTINO & UN R $\$$ & 45,90 & 59,67 \\
\hline HATA UA IKHAL (LENÇO E CORDÃO) & UN R\$ & 15,00 & 19,50 \\
\hline CACHECOL PALESTINO & UN RȘ & 20,00 & 26,00 \\
\hline
\end{tabular}

A única forma de venda dos produtos árabes, a princípio, será no balcão da própria loja. Todos os produtos terão consigo um cartão explicativo. Este cartão terá um breve relato sobre a mística que envolve este produto e algumas aplicabilidades, para que os menos entendidos compreendam, se interessem e aprendam a consumir mais os produtos árabes. 
A empresa tem como principal diferencial fazer com que o cliente, ao entrar na empresa, sinta-se em terras árabes, tanto na qualidade dos produtos quanto nos serviços prestados (atendimento).

\section{Base tecnológica}

A empresa necessitará, em um primeiro momento, de um computador para o caixa, uma linha telefônica para contato com clientes e fornecedores, impressora e fotocopiadora e um programa de controle dos produtos.

\begin{tabular}{|l|c|c|c|}
\hline & Quantidade & Valor Unitário & Valor Total \\
\hline Aparelhos telefônicos & 1 & 100,00 & 100,00 \\
\hline Computador & 1 & 1000,00 & 1000,00 \\
\hline Impressora & 1 & 250,00 & 250,00 \\
\hline Impressora fiscal & 1 & 2000,00 & 2000,00 \\
\hline Sistema & 1 & 500,00 & 500,00 \\
\hline Televisão & 1 & 1200,00 & 1200,00 \\
\hline DVD & 1 & 200,00 & 200,00 \\
\hline
\end{tabular}

\section{Produtos e serviços futuros}

Entre os produtos que só serão fornecidos de acordo com 0 desenvolvimento da empresa temos: lanches preparados na hora; ambiente para fumar Narguile; apresentações de dança do ventre; e preparação de pratos árabes para degustação na própria empresa. 


\section{PLANO DE MARKETING}

\section{Análise de mercado}

Segundo estudo "A Competitividade em setores de Comércio, de Serviços e do Turismo no Brasil. Perspectivas até 2015", realizado em 2005, do instituto SEBRAE, o comércio varejista pode ser segregado em dois grandes grupos. $O$ primeiro corresponde ao segmento de hiper e supermercados, maior fonte de receita do varejo, com 40,7\% da receita varejista e 13,3\% da receita total do comércio em 2005. O segundo é formado por todo o comércio especializado.

Ao final de 2005, o setor ocupava no Brasil mais de 5 milhões de pessoas, gerando uma receita operacional liquida de quase $\mathrm{R} \$ 400$ bilhões. Mais de 1,2 milhões de empresas pagaram $\mathrm{R} \$ 34$ bilhões em salários, retiradas e outras remunerações. Em numero de empresas o setor é quase totalmente composto por micro, pequenas e médias empresas $(99,87 \%)$. No entanto, em termos de pessoal ocupado e receita total, por exemplo, a participação das empresas de grande porte aumenta substancialmente, respondendo por $19 \%$ e $38 \%$ respectivamente.

O CANTINHO ÁRABE será uma empresa no ramo do comércio varejista voltado para alimentação, bebidas, etc., ofertando mercadorias diretamente aos consumidores. Conforme indicado na distribuição de setores do comércio do SEBRAE, o CANTINHO ÁRABE é classificado como varejo especializado em alimento, bebida e fumo. 


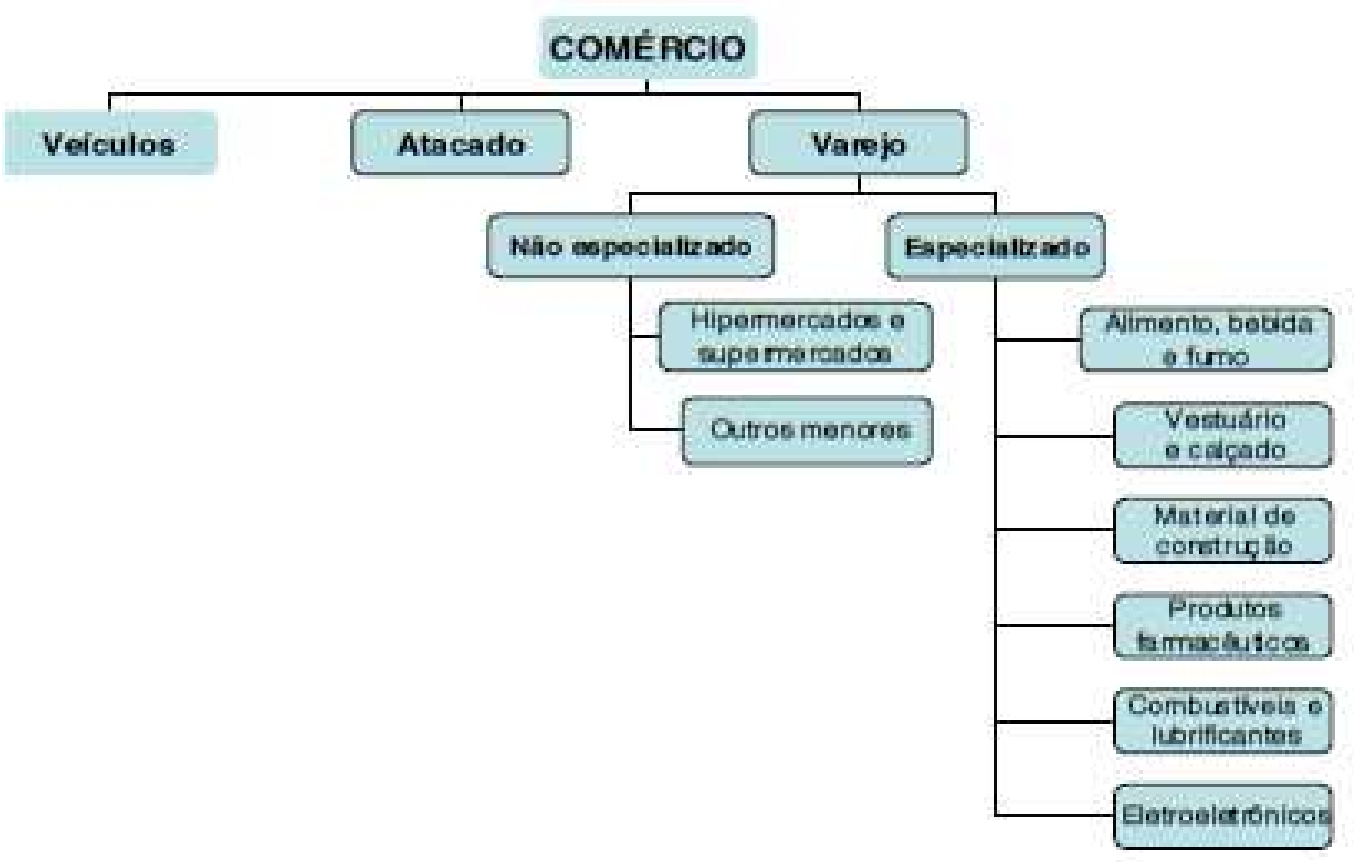

Fonte: A Competitividade em setores de comércio, de serviços e do turismo no Brasil. Perspectivas até 2015. SEBRAE, 2005.

O comércio de Brasília nessa área de produtos árabes é bastante escasso, só é possível encontrar um estabelecimento com o mesmo ramo de atuação do CANTINHO ÁRABE..

É possível encontrar outros serviços envolvendo a cultura árabe, mas estão em ramos diferentes como: cafés, bares e restaurantes, não sendo também caracterizados como concorrentes diretos.

Com a abertura do CANTINHO ÁRABE, as pessoas que se interessam por produtos árabes terão onde apreciar e adquirir de forma prática, em horário comercial, todos os produtos que desejarem.

\section{Análise da concorrência}

Em relação à concorrência, após a aplicação de questionário há potenciais clientes. Constatou-se que não há um nome conhecido e fixado na cabeça dos clientes com relação às empresas que comercializam produtos árabes. A somente 
uma única empresa que tem as mesmas características do CANTINHO ÁRABE, localizado Plano Piloto (Brasília), Asa Sul, DF.

Em relação aos pontos fortes da concorrência, é possível destacar:

$\checkmark$ Marca: é a única empresa que vende esses produtos na região e está no mercado há mais tempo.

$\checkmark$ Facilidade na concorrência: como é a única que vende produtos árabes na região, há pouca concorrência neste setor.

Em relação aos pontos fracos da concorrência, destacam-se:

$\checkmark$ Espaço físico: o ambiente não remete à cultura árabe.

Após a análise da concorrência e aplicação de questionário com potenciais clientes, foi possível perceber que mesmo a empresa tendo muito tempo no mercado, ela não é conhecida na região. É possível, portanto, criar diferenciais nesse mercado a partir de uma empresa que foque os pontos fracos da concorrência e divulgue o empreendimento.

\section{Análise SWOT}

\subsection{Pontos fortes}

$\checkmark$ Qualidade: a empresa oferecerá aos seus clientes produtos de qualidade, além de um atendimento diferenciado e personalizado onde os funcionários terão postura, educação no modo de falar, forma de abordar atenciosa, além de tratar o cliente pelo nome; contando também com um site exclusivo mostrando os principais produtos oferecidos pela empresa.

$\checkmark$ Preço: a preocupação com os preços dos produtos ofertados será uma constante da empresa.

$\checkmark$ Especialização no segmento: atualmente, só existe uma empresa ofertando os mesmo produtos no mercado de Brasília. O CANTINHO ÁRABE contará com um ambiente contextualizado para atrair os admiradores desses produtos. 


\subsection{Pontos fracos}

Dependência de fornecedores: a empresa ficará na dependência dos fornecedores para venda dos produtos. Sendo assim, a empresa trabalhará com dois fornecedores ao mesmo tempo, considerando a possibilidade da perda de um dos mesmos. Torna-se necessário manter um estreito relacionamento com os fornecedores, bem como manter outros sob consideração caso qualquer outro problema aconteça.

Busca de especializações: por se tratar de uma empresa com produtos que não são comuns no mercado, a inexperiência deve ser considerada. Portanto, a empresa terá estratégias em promoção, através das quais atrairá mais clientes, alinhando assim, suas necessidades aos produtos oferecidos pelo CANTINHO ÁRABE.

\subsection{Ameaças}

$\checkmark$ Preço dos produtos árabes no mercado: os valores praticados pelos atacadistas de produtos árabes podem ser uma ameaça para o CANTINHO ÁRABE, já que eles são os fornecedores do negócio, o que faz dessa dependência uma forte ameaça.

$\checkmark$ Crise econômica: a crise pode ser uma ameaça por se tratar de produtos importados, se temos um aumento das taxas de inflação ou aumento da taxa de juros a um patamar muito elevados, os reflexos negativos podem afetar diretamente ao CANTINHO ÁRABE.

\subsection{Oportunidades}

$\checkmark$ Concorrência: é uma oportunidade, por haver somente uma empresa que oferece produtos árabes na região de abertura do negócio.

\section{Marketing Mix}

\section{Produto (Posicionamento)}

A visão que se espera dos clientes é que no CANTINHO ÁRABE ele possa encontrar toda gama de produtos árabes, com toda a qualidade (melhores sabores, higiene total, durabilidade) e principalmente com um atendimento exemplar. 


\section{Preço}

Mesmo sendo um produto diferenciado, ele não é uma novidade. É possível pensar em uma estratégia de preços de penetração, vendendo o mais barato possível para conquistar os clientes e depois pensar em lucrar mais.

\section{Praça}

A empresa estará situada nas entre quadras na Asa Sul, sendo uma das regiões mais bem localizadas de Brasília, estrategicamente a empresa poderá atender todas as pessoas que trabalham naquela região ou que residem na mesma. O acesso se torna fácil devido as vias, podendo se dirigir a empresa tanto pela W3, Eixo ou L2.

\section{Promoção}

$\checkmark$ Através de um site muito bem elaborado, onde o cliente saberá da abertura do CANTINHO ÁRABE e também quais os produtos serão fornecidos.

$\checkmark$ Serão formadas alianças com as embaixadas árabes para conseguir aumentar a cartela de clientes do oriente médio através do envio de correspondências personalizadas contendo um convite de visita à loja.

$\checkmark$ Prospectando clientes através de panfletagens na Asa Sul.

$\checkmark$ Estandes e materiais de apresentação no maior número possível de feiras de produtos árabes.

$\checkmark$ As vendas deverão ser realizadas por profissionais que conheçam os produtos árabes e que possam tirar todas as dúvidas dos clientes. 


\section{ESTRUTURA OPERACIONAL}

\section{Estrutura física da empresa}

A empresa utilizará os critérios econômicos apropriados no planejamento e execução das obras para o estabelecimento da infra-estrutura necessárias. A empresa compreende em seu espaço físico um espaço para prateleira e gôndolas para a exposição dos produtos, um espaço menor para estoques, e um local bastante simplificado para cozinha.

A seguir, são apresentadas as tabelas com descrições de todos os equipamentos que serão utilizados para o funcionamento da empresa.

\begin{tabular}{|c|c|c|c|}
\hline Mobília & Quantidade & Valor Unitário & Valor Total \\
\hline Aparelhos telefônicos & 1 & 100,00 & 100,00 \\
\hline Computador & 1 & 1000,00 & 1000,00 \\
\hline Impressora & 1 & 250,00 & 250,00 \\
\hline Impressora fiscal & 1 & 2000,00 & 2000,00 \\
\hline Sistema & 1 & 500,00 & 500,00 \\
\hline Televisao & 1 & 1200,00 & 1200,00 \\
\hline DVD & 1 & 200,00 & 200,00 \\
\hline Cadeira de escritório & 1 & 250,00 & 250,00 \\
\hline Estrutura & Quantidade & Valor Unitário & Valor Total \\
\hline Balcões & 3 & 500,00 & 1500,00 \\
\hline Prateleiras & 10 & 100,00 & 1000,00 \\
\hline Vitrine Refrigerada & 1 & 650,00 & 650,00 \\
\hline Vitrine Aquecida & 1 & 600,00 & 600,00 \\
\hline Máquina de café & 1 & 700,00 & 700,00 \\
\hline Forno elétrico & 1 & 300,00 & 300,00 \\
\hline Forno microondas & 1 & 300,00 & 300,00 \\
\hline Fogão & 1 & 450,00 & 450,00 \\
\hline Freezer & 1 & 1000,00 & 1000,00 \\
\hline Geladeira & 1 & 800,00 & 800,00 \\
\hline Ar Condicionado & 1 & 2000,00 & 2000,00 \\
\hline Utensílios & Quantidade & Valor Unitário & Valor Total \\
\hline Extintor de incêndio & 1 & 60,00 & 60,00 \\
\hline Jalecos & 4 & 35,00 & 140,00 \\
\hline Lata de lixos convencionais & 5 & 30,00 & 150,00 \\
\hline Potes e embalagens & - & 500,00 & 500,00 \\
\hline Talheres e bandejas & - & 500,00 & 500,00 \\
\hline
\end{tabular}




\begin{tabular}{|c|c|c|c|}
\hline Obras & Dias úteis (implantação) & Valor Unitário & Valor Total \\
\hline Reforma da sala & 10 & 3500,00 & 3500,00 \\
\hline Reforma dos banheiros & 2 & 500,00 & 500,00 \\
\hline Reforma fachada & 5 & 2000,00 & 2000,00 \\
\hline Instalações elétricas & 1 & 200,00 & 200,00 \\
\hline Pinturas Gerais & 2 & 500,00 & 500,00 \\
\hline Limpeza final da sala & 1 & 100,00 & 100,00 \\
\hline
\end{tabular}

\section{Disposição interna}

O layout da empresa apresenta-se de forma simples. A empresa será divida em três blocos. O primeiro bloco será na abertura da porta comercial, onde, ao entrar, o cliente contará os produtos arrumados em prateleiras, balcões e vitrines refrigeradas para melhor localização/visualização dos produtos.

O segundo bloco estará localizado em uma sala separada ao fundo da sala comercial, onde os produtos estarão estocados. O fornecedor entregará os produtos e, havendo necessidade, eles serão repostos nas prateleiras.

E o terceiro bloco, que também estará localizado no fundo da sala comercial, será a pequena cozinha. 


\section{ORGANIZAÇÃO E GERÊNCIA}

\section{Estrutura organizacional}

Toda a parte operacional da empresa, recursos humanos, vendas, marketing, logística, materiais ficará por conta de uma das sócias, a diretora administrativa Daiany Ottoni. A parte financeira da empresa ficará a cargo do outro sócio da empresa, que será o diretor financeiro. Em relação a vendas, a empresa contará, em um primeiro momento, somente com uma vendedora. O aumento da quantidade de vendedores será conforme o crescimento da empresa, ficando definido que todos os departamentos devem ter interação de tudo o que acontece na empresa.

\subsection{Critérios de recompensa}

Os vendedores serão remunerados, além do salário, com uma comissão de $3 \%$ sobre as vendas realizadas.

\subsection{Treinamento dos funcionários}

Todos os funcionários terão um treinamento ministrado por Daiany e Marcelo. Nele, serão abordados:

$\checkmark$ Os produtos da empresa;

$\checkmark$ A forma de abordagem aos clientes, e a importância desta para a promoção da empresa;

$\checkmark$ A forma de atender aos telefonemas/pedido de clientes e fornecedores;

$\checkmark$ O dia-a-dia da empresa;

$\checkmark$ Missão e Visão do CANTINHO ÁRABE. 


\section{Organograma proposto}

Este organograma retrata as subordinações, assim como o fluxo das decisões da empresa

\section{Diretor Administrativo}

\section{Diretor Financeiro}

\section{Vendedores}




\section{PLANO FINANCEIRO}

\section{Pressupostos financeiros}

Para a abertura do CANTINHO ÁRABE foram considerados três pressupostos, primeiro, que a empresa atenderá 390 clientes por mês, visto que em Brasília (Asa Sul, Asa Norte, Lago Sul e Lago Norte), estima-se ter em torno de 200.000 habitantes, com isso a meta da empresa é fazer com que se tornem clientes potenciais $0,2 \%$ dessa população, sendo assim será possível atender 390 clientes por mês.

Segundo, que cada cliente gastaria em média por dia $\mathrm{R} \$ 30,00$ na empresa. Distribuídos em alimento, bebida e souvenires, esta média foi embasada no custo médio destes mesmos produtos, e nos questionários aplicados com potenciais clientes.

Considerando as estimativas de número de clientes e de valor médio gasto por cliente, a empresa terá uma receita bruta de $R \$ 11.700,00$ no primeiro mês. Este valor será reajustado com o passar do tempo, considerando uma receita crescente de $5 \%$ no primeiro ano, de $3 \%$ no segundo e terceiro ano e $2 \%$ no quarto e quinto ano. Após entrevista indireta com o proprietário de um empreendimento que fornece produtos árabes foi possível chegar nesses valores.

O investimento inicial será de $R \$ 22.950,00$ além do desembolso operacional de $R \$ 13.164,82$ para primeiro mês. Dessa forma foi estipulado um empréstimo de $R \$ 35.000,00$.

A partir do oitavo mês a empresa encontrará o ponto de equilíbrio, contudo, só terá lucro a partir do primeiro mês do segundo ano, devido o início do pagamento do empréstimo a partir do sexto mês. No início do terceiro ano está previsto uma reforma e expansão da empresa, assim foi considerado um aumento do número de funcionários. 


\begin{tabular}{|c|c|c|}
\hline \multicolumn{3}{|l|}{ Previsão de Receita } \\
\hline Previsão de clientes/dia & \multicolumn{2}{|r|}{15} \\
\hline Gasto médio por cliente & \multicolumn{2}{|c|}{30,00} \\
\hline Dias aberto por mês & \multicolumn{2}{|r|}{26} \\
\hline \multirow{5}{*}{ Taxa de crescimento mensal de vendas } & Ano 1 & $5 \%$ \\
\hline & Ano 2 & $3 \%$ \\
\hline & Ano 3 & $3 \%$ \\
\hline & Ano 4 & $2 \%$ \\
\hline & Ano 5 & $2 \%$ \\
\hline Custo do produto (\% sobre a receita) & \multicolumn{2}{|c|}{$65 \%$} \\
\hline
\end{tabular}

\begin{tabular}{|r|r|r|}
\hline \multicolumn{3}{|c|}{ Previsão de Receita 1o Ano } \\
\hline Mês & Receita/Dia & Receita/Mês \\
\hline 1 & 450,00 & 11700,00 \\
\hline 2 & 472,50 & 12285,00 \\
\hline 3 & 496,13 & 12899,25 \\
\hline 4 & 520,93 & 13544,21 \\
\hline 5 & 546,98 & 14221,42 \\
\hline 6 & 574,33 & 14932,49 \\
\hline 7 & 603,04 & 15679,12 \\
\hline 8 & 633,20 & 16463,07 \\
\hline 9 & 664,85 & 17286,23 \\
\hline 10 & 698,10 & 18150,54 \\
\hline 11 & 733,00 & 19058,07 \\
\hline 12 & 769,65 & 20010,97 \\
\hline
\end{tabular}

\begin{tabular}{|r|r|r|}
\hline \multicolumn{3}{|c|}{ Previsão de Receita $2^{\circ}$ Ano } \\
\hline Mês & Receita/Dia & Receita/Mês \\
\hline 1 & 792,74 & 20611,30 \\
\hline 2 & 816,52 & 21229,64 \\
\hline 3 & 841,02 & 21866,53 \\
\hline 4 & 866,25 & 22522,52 \\
\hline 5 & 892,24 & 23198,20 \\
\hline 6 & 919,01 & 23894,15 \\
\hline 7 & 946,58 & 24610,97 \\
\hline 8 & 974,97 & 25349,30 \\
\hline 9 & 1004,22 & 26109,78 \\
\hline 10 & 1034,35 & 26893,07 \\
\hline 11 & 1065,38 & 27699,86 \\
\hline 12 & 1097,34 & 28530,86 \\
\hline
\end{tabular}

\begin{tabular}{|r|r|r|}
\hline \multicolumn{3}{|c|}{ Previsão de Receita 3 Ano } \\
\hline Mês & Receita/Dia & Receita/Mês \\
\hline 1 & 1130,26 & 29386,78 \\
\hline 2 & 1164,17 & 30268,39 \\
\hline 3 & 1199,09 & 31176,44 \\
\hline 4 & 1235,07 & 32111,73 \\
\hline 5 & 1272,12 & 33075,09 \\
\hline 6 & 1310,28 & 34067,34 \\
\hline 7 & 1349,59 & 35089,36 \\
\hline 8 & 1390,08 & 36142,04 \\
\hline 9 & 1431,78 & 37226,30 \\
\hline 10 & 1474,73 & 38343,09 \\
\hline 11 & 1518,98 & 39493,38 \\
\hline 12 & 1564,55 & 40678,18 \\
\hline
\end{tabular}

\begin{tabular}{|r|r|r|}
\hline \multicolumn{3}{|c|}{ Previsão de Receita 4 Ano } \\
\hline Mês & Receita/Dia & Receita/Mês \\
\hline 1 & 1595,84 & 41491,75 \\
\hline 2 & 1627,75 & 42321,58 \\
\hline 3 & 1660,31 & 43168,01 \\
\hline 4 & 1693,51 & 44031,37 \\
\hline 5 & 1727,38 & 44912,00 \\
\hline 6 & 1761,93 & 45810,24 \\
\hline 7 & 1797,17 & 46726,45 \\
\hline 8 & 1833,11 & 47660,97 \\
\hline 9 & 1869,78 & 48614,19 \\
\hline 10 & 1907,17 & 49586,48 \\
\hline 11 & 1945,32 & 50578,21 \\
\hline 12 & 1984,22 & 51589,77 \\
\hline
\end{tabular}

\begin{tabular}{|r|r|r|}
\hline \multicolumn{3}{|c|}{ Previsão de Receita 5 Ano } \\
\hline Mês & Receita/Dia & Receita/Mês \\
\hline 1 & 2023,91 & 52621,57 \\
\hline 2 & 2064,38 & 53674,00 \\
\hline 3 & 2105,67 & 54747,48 \\
\hline 4 & 2147,79 & 55842,43 \\
\hline 5 & 2190,74 & 56959,28 \\
\hline 6 & 2234,56 & 58098,46 \\
\hline 7 & 2279,25 & 59260,43 \\
\hline 8 & 2324,83 & 60445,64 \\
\hline 9 & 2371,33 & 61654,55 \\
\hline 10 & 2418,76 & 62887,64 \\
\hline 11 & 2467,13 & 64145,40 \\
\hline 12 & 2516,47 & 65428,30 \\
\hline
\end{tabular}




\begin{tabular}{|l|c|}
\hline \multicolumn{1}{|c|}{ Descrição dos custos fixos } & Valor em R\$ \\
\hline Aluguel da loja & $2.500,00$ \\
\hline Água, energia elétrica & 120,00 \\
\hline Telefone, Internet & 120,00 \\
\hline Pessoal Salário/Encargos & 991,82 \\
\hline Pró-Labore & 300,00 \\
\hline Despesas com veiculo & 100,00 \\
\hline Taxas de Bancos & 50,00 \\
\hline Contador & 760,00 \\
\hline Material de escritório e diversos & 150,00 \\
\hline
\end{tabular}

\begin{tabular}{|l|r|}
\hline \multicolumn{2}{|c|}{ Remuneração e Encargos } \\
\hline Encargos trabalhistas & $80 \%$ \\
\hline Salário Mínimo & 465,00 \\
\hline Soma & 837,00 \\
\hline Comissão dos vendedores & $3 \%$ \\
\hline
\end{tabular}




\section{Fluxo de caixa}

\begin{tabular}{|c|c|c|c|c|c|c|c|c|c|c|c|c|}
\hline \multicolumn{13}{|c|}{ Fluxo de Caixa 1응 Ano } \\
\hline Valores em Reais (R\$) & Mês 1 & Mês 2 & Mês 3 & Mês 4 & Mês 5 & Mês 6 & Mês 7 & Mês 8 & Mês 9 & Mês 10 & Mês 11 & Mês 12 \\
\hline \multicolumn{13}{|c|}{ I - ATIVIDADES OPERACIONAIS } \\
\hline \multicolumn{13}{|l|}{ Embolsos Operacionais } \\
\hline Receita com vendas & $11.700,00$ & $12.285,00$ & $12.899,25$ & $13.544,21$ & $14.221,42$ & $14.932,49$ & $15.679,12$ & $16.463,07$ & $17.286,23$ & $18.150,54$ & $19.058,07$ & $20.010,97$ \\
\hline \multicolumn{13}{|l|}{ Desembolsos Operacionais } \\
\hline Custo do produto & $7.605,00$ & $7.985,25$ & $8.384,51$ & $8.803,74$ & $9.243,93$ & $9.706,12$ & $10.191,43$ & $10.701,00$ & $11.236,05$ & $11.797,85$ & $12.387,74$ & $13.007,13$ \\
\hline Aluguel da loja & $2.500,00$ & $2.500,00$ & $2.500,00$ & $2.500,00$ & $2.500,00$ & $2.500,00$ & $2.500,00$ & $2.500,00$ & $2.500,00$ & $2.500,00$ & $2.500,00$ & $2.500,00$ \\
\hline Água, energia elétrica & 120,00 & 120,00 & 120,00 & 120,00 & 120,00 & 120,00 & 120,00 & 120,00 & 120,00 & 120,00 & 120,00 & 120,00 \\
\hline Telefone, Internet & 120,00 & 120,00 & 120,00 & 120,00 & 120,00 & 120,00 & 120,00 & 120,00 & 120,00 & 120,00 & 120,00 & 120,00 \\
\hline Pessoal Salário/Encargos & 991,82 & 991,82 & 991,82 & 991,82 & 991,82 & 991,82 & 991,82 & 991,82 & 991,82 & 991,82 & 991,82 & $1.983,64$ \\
\hline Comissão vendedores & 175,50 & 184,28 & 193,49 & 203,16 & 213,32 & 223,99 & 235,19 & 246,95 & 259,29 & 272,26 & 285,87 & 300,16 \\
\hline Pró-Labore & 300,00 & 300,00 & 300,00 & 300,00 & 300,00 & 300,00 & 300,00 & 300,00 & 300,00 & 300,00 & & \\
\hline Marketing & & & $1.000,00$ & & & & 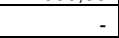 & & & - & & \\
\hline Despesas com veiculo & 100,00 & 200,00 & 200,00 & 200,00 & 200,00 & 200,00 & 200,00 & 200,00 & 200,00 & 200,00 & 200,00 & 200,00 \\
\hline Taxas de Bancos & 50,00 & 50,00 & 50,00 & 50,00 & 50,00 & 50,00 & 50,00 & 50,00 & 50,00 & 50,00 & 50,00 & 50,00 \\
\hline Contador & 760,00 & 460,00 & 460,00 & 460,00 & 460,00 & 460,00 & 460,00 & 460,00 & 460,00 & 460,00 & 460,00 & 920,00 \\
\hline Material de escritório e diversos & 150,00 & 150,00 & 150,00 & 150,00 & 150,00 & 150,00 & 150,00 & 150,00 & 150,00 & 150,00 & 150,00 & 150,00 \\
\hline ICMS (Regime simplificado - SIMPLES) & 292,50 & 307,13 & 322,48 & 338,61 & 355,54 & 373,31 & 391,98 & 411,58 & 432,16 & 453,76 & 476,45 & 500,27 \\
\hline Fluxo operacional líquido & $(1.464,82)$ & $(1.083,47)$ & $(1.893,05)$ & $(693,11)$ & $(483,18)$ & $(262.75)$ & $(31,29)$ & 211,73 & 466,91 & 734.85 & $1.316,18$ & 159,76 \\
\hline \multicolumn{13}{|c|}{ II - ATIVIDADES DE INVESTIMENTOS } \\
\hline \multicolumn{13}{|l|}{ Desembolsos para Investimentos } \\
\hline Obras, Móveis e Utensílios & $22.950,00$ & -1 & - & - & -1 & & - & - & -1 & - & - & \\
\hline Fluxo de investimento líquido & $(22.950,00)$ & & - & & & & - & -1 & & (1) & & \\
\hline \multicolumn{13}{|c|}{ II - ATIVIDADES DE FINANCIAMENTOS } \\
\hline \multicolumn{13}{|l|}{ Embolsos de Financiamentos } \\
\hline Empréstimos & $35.000,00$ & -1 & - & - & -1 & -1 & - & -1 & -1 & - & 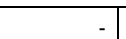 & \\
\hline \multicolumn{13}{|l|}{ Desembolsos de Financiamentos } \\
\hline Amortização de empréstimos & & & & & & & $1.500,00$ & $1.500,00$ & $1.500,00$ & $1.500,00$ & \begin{tabular}{l|l|l}
$1.500,00$ \\
\end{tabular} & $1.500,00$ \\
\hline Fluxo financiamentos líquido & $35.000,00$ & - & - & - & - & - & $(1.500,00)$ & $(1.500,00)$ & $(1.500,00)$ & $(1.500,00)$ & \begin{tabular}{l|l}
$(1.500,00)$ \\
\end{tabular} & $(1.500,00)$ \\
\hline Caixa líquido por período & $10.585,18$ & $(1.083,47)$ & $(1.893,05)$ & $(693,11)$ & $(483,18)$ & $(262,75)$ & $(1.531,29)$ & $(1.288,27)$ & $(1.033,09)$ & $(765,15)$ & $(183,82)$ & $(1.340,24)$ \\
\hline Saldo inicial das disponibilidades & -1 & $10.585,18$ & $9.501,71$ & $7.608,66$ & $6.915,54$ & $6.432,36$ & $6.169,62$ & $4.638,32$ & $3.350,06$ & $2.316,97$ & $1.551,82$ & $1.368,00$ \\
\hline Saldo final das disponibilidades & $10.585,18$ & $9.501,71$ & $7.608,66$ & $6.915,54$ & $6.432,36$ & $6.169,62$ & $4.638,32$ & $3.350,06$ & $2.316,97$ & $1.551,82$ & $1.368,00$ & 27,76 \\
\hline
\end{tabular}




\begin{tabular}{|c|c|c|c|c|c|c|c|c|c|c|c|c|}
\hline \multicolumn{13}{|c|}{ Fluxo de Caixa 2o Ano } \\
\hline Valores em Reais (R\$) & Mês 1 & Mês 2 & Mês 3 & Mês 4 & Mês 5 & Mês 6 & Mês 7 & Mês 8 & Mês 9 & Mês 10 & Mês 11 & Mês 12 \\
\hline \multicolumn{13}{|c|}{ I - ATIVIDADES OPERACIONAIS } \\
\hline \multicolumn{13}{|l|}{ Embolsos Operacionais } \\
\hline Receita com vendas & $20.611,30$ & $21.229,64$ & $21.866,53$ & $22.522,52$ & $23.198,20$ & $23.894,15$ & $24.610,97$ & $25.349,30$ & \begin{tabular}{l|l|}
$26.109,78$ \\
\end{tabular} & $26.893,07$ & $27.699,86$ & $28.530,86$ \\
\hline \multicolumn{13}{|l|}{ Desembolsos Operacionais } \\
\hline Custo do produto & $13.397,34$ & $13.799,27$ & $14.213,24$ & $14.639,64$ & $15.078,83$ & $15.531,19$ & $15.997,13$ & $16.477,04$ & $16.971,36$ & $17.480,50$ & $18.004,91$ & $18.545,06$ \\
\hline Aluguel da loja & $2.500,00$ & $2.500,00$ & $2.500,00$ & $2.500,00$ & $2.500,00$ & $2.500,00$ & $2.500,00$ & $2.500,00$ & $2.500,00$ & $2.500,00$ & $2.500,00$ & $2.500,00$ \\
\hline Água, energia elétrica & 120,00 & 120,00 & 120,00 & 120,00 & 120,00 & 120,00 & 120,00 & 120,00 & 120,00 & 120,00 & 120,00 & 120,00 \\
\hline Telefone, Internet & 120,00 & 120,00 & 120,00 & 120,00 & 120,00 & 120,00 & 120,00 & 120,00 & 120,00 & 120,00 & 120,00 & 120,00 \\
\hline Pessoal Salário/Encargos & 991,82 & 991,82 & 991,82 & 991,82 & 991,82 & 991,82 & 991,82 & 991,82 & 991,82 & 991,82 & 991,82 & $1.983,64$ \\
\hline Comissão vendedores & 309,17 & 318,44 & 328,00 & 337,84 & 347,97 & 358,41 & 369,16 & 380,24 & 391,65 & 403,40 & 415,50 & 427,96 \\
\hline Pró-Labore & -1 & - & 500,00 & 500,00 & 500,00 & 500,00 & 500,00 & 500,00 & 500,00 & 500,00 & 500,00 & 500,00 \\
\hline Marketing & & - & & & & & $1.000,00$ & & & & & \\
\hline Despesas com veiculo & 200,00 & 200,00 & 200,00 & 200,00 & 200,00 & 200,00 & 200,00 & 200,00 & 200,00 & 200,00 & 200,00 & 200,00 \\
\hline Taxas de Bancos & 50,00 & 50,00 & 50,00 & 50,00 & 50,00 & 50,00 & 50,00 & 50,00 & 50,00 & 50,00 & 50,00 & 50,00 \\
\hline Contador & 460,00 & 460,00 & 460,00 & 460,00 & 460,00 & 460,00 & 460,00 & 460,00 & 460,00 & 460,00 & 460,00 & 920,00 \\
\hline Material de escritório e diversos & 150,00 & 150,00 & 150,00 & 150,00 & 150,00 & 150,00 & 150,00 & 150,00 & \begin{tabular}{l|l}
150,00 \\
\end{tabular} & 150,00 & 150,00 & 150,00 \\
\hline ICMS (Regime simplificado - SIMPLES) & 515,28 & 530,74 & 546,66 & 563,06 & 579,95 & 597,35 & 615,27 & 633,73 & 652,74 & 672,33 & 692,50 & 713,27 \\
\hline Fluxo operacional líquido & $1.797,68$ & $1.989,37$ & $1.686,80$ & $1.890,16$ & $2.099,62$ & $2.315,37$ & $1.537,58$ & $2.766,46$ & $3.002,21$ & $3.245,03$ & $3.495,14$ & $2.300,93$ \\
\hline \multicolumn{13}{|c|}{ II - ATIVIDADES DE INVESTIMENTOS } \\
\hline Desembolsos para Investimentos & & & & & & & & & & & & \\
\hline Obras, Móveis e Utensílios & -1 & - & - & - & & & -1 & -1 & -1 & & - & \\
\hline Fluxo de investimento líquido & -1 & - & - & & & & - & - & -1 & & 7 & \\
\hline \multirow{2}{*}{\multicolumn{13}{|c|}{ Embolsos de Financiamentos }} \\
\hline & & & & & & & & & & & & \\
\hline Empréstimos & -1 & - & - & -1 & -1 & -1 & -1 & -1 & -1 & -1 & -1 & \\
\hline Desembolsos de Financiamentos & & & & & & & & & & & & \\
\hline Amortização de empréstimos & $1.500,00$ & $1.500,00$ & $1.500,00$ & $1.500,00$ & $1.500,00$ & $1.500,00$ & $1.500,00$ & $1.500,00$ & \begin{tabular}{l|l}
$1.500,00$ \\
\end{tabular} & $1.500,00$ & $1.500,00$ & $1.500,00$ \\
\hline Fluxo financiamentos líquido & $(1.500,00)$ & $(1.500,00)$ & $(1.500,00)$ & $(1.500,00)$ & $(1.500,00)$ & $(1.500,00)$ & $(1.500,00)$ & $(1.500,00)$ & $(1.500,00)$ & $(1.500,00)$ & $(1.500,00)$ & $(1.500,00)$ \\
\hline Caixa líquido por período & 297,68 & 489,37 & 186,80 & 390,16 & 599,62 & 815,37 & 37,58 & $1.266,46$ & $1.502,21$ & $1.745,03$ & $1.995,14$ & 800,93 \\
\hline & & & & & & & & & & & & \\
\hline Saldo inicial das disponibilidades & 27,76 & 325,44 & 814,81 & $1.001,61$ & $1.391,77$ & $1.991,40$ & $2.806,76$ & $2.844,34$ & $4.110,80$ & $5.613,02$ & $7.358,05$ & $9.353,19$ \\
\hline Saldo final das disponibilidades & 325,44 & 814,81 & $1.001,61$ & $1.391,77$ & $1.991,40$ & $2.806,76$ & $2.844,34$ & $4.110,80$ & $5.613,02$ & 7.358 .05 & $9.353,19$ & $10.154,11$ \\
\hline
\end{tabular}




\begin{tabular}{|c|c|c|c|c|c|c|c|c|c|c|c|c|}
\hline \multicolumn{13}{|c|}{ Fluxo de Caixa $3 \circ$ Ano } \\
\hline Valores em Reais (R\$) & Mês 1 & Mês 2 & Mês 3 & Mês 4 & Mês 5 & Mês 6 & Mês 7 & Mês 8 & Mês 9 & Mês 10 & Mês 11 & Mês 12 \\
\hline \multicolumn{13}{|c|}{ I - ATIVIDADES OPERACIONAIS } \\
\hline \multicolumn{13}{|l|}{ Embolsos Operacionais } \\
\hline Receita com vendas & $29.386,78$ & $30.268,39$ & $31.176,44$ & $32.111,73$ & $33.075,09$ & $34.067,34$ & $35.089,36$ & $36.142,04$ & $37.226,30$ & $38.343,09$ & $39.493,38$ & $40.678,18$ \\
\hline \multicolumn{13}{|l|}{ Desembolsos Operacionais } \\
\hline Custo do produto & $19.101,41$ & $19.674,45$ & $20.264,69$ & $20.872,63$ & $21.498,81$ & $22.143,77$ & $22.808,08$ & $23.492,33$ & $24.197,09$ & $24.923,01$ & $25.670,70$ & $26.440,82$ \\
\hline Aluguel da loja & $2.500,00$ & $2.500,00$ & $2.500,00$ & $2.500,00$ & $2.500,00$ & $2.500,00$ & $2.500,00$ & $2.500,00$ & $2.500,00$ & $2.500,00$ & $2.500,00$ & $2.500,00$ \\
\hline Água, energia elétrica & 120,00 & 120,00 & 120,00 & 120,00 & 120,00 & 120,00 & 120,00 & 120,00 & 120,00 & 120,00 & 120,00 & 120,00 \\
\hline Telefone, Internet & 120,00 & 120,00 & 120,00 & 120,00 & 120,00 & 120,00 & 120,00 & 120,00 & 120,00 & 120,00 & 120,00 & 120,00 \\
\hline Pessoal Salário/Encargos & 991,82 & $1.983,64$ & $1.983,64$ & $1.983,64$ & $1.983,64$ & $1.983,64$ & $1.983,64$ & $1.983,64$ & $1.983,64$ & $1.983,64$ & $1.983,64$ & $3.967,28$ \\
\hline Comissão vendedores & 440,80 & 908,05 & 935,29 & 963,35 & 992,25 & $1.022,02$ & $1.052,68$ & $1.084,26$ & $1.116,79$ & $1.150,29$ & $1.184,80$ & $1.220,35$ \\
\hline Pró-Labore & $1.000,00$ & $1.000,00$ & $1.000,00$ & $1.000,00$ & $1.000,00$ & $1.000,00$ & $1.000,00$ & $1.000,00$ & $1.000,00$ & $1.000,00$ & $1.000,00$ & $1.000,00$ \\
\hline Marketing & $1.000,00$ & & & & & & $1.000,00$ & & & & & \\
\hline Despesas com veiculo & 200,00 & 200,00 & 200,00 & 200,00 & 200,00 & 200,00 & 200,00 & 200,00 & 200,00 & 200,00 & 200,00 & 200,00 \\
\hline Taxas de Bancos & 50,00 & 50,00 & 50,00 & 50,00 & 50,00 & 50,00 & 50,00 & 50,00 & 50,00 & 50,00 & 50,00 & 50,00 \\
\hline Contador & 460,00 & 460,00 & 460,00 & 460,00 & 460,00 & 460,00 & 460,00 & 460,00 & 460,00 & 460,00 & 460,00 & 920,00 \\
\hline Material de escritório e diversos & 150,00 & 150,00 & 150,00 & 150,00 & 150,00 & 150,00 & 150,00 & 150,00 & 150,00 & 150,00 & 150,00 & 150,00 \\
\hline ICMS (Regime simplificado - SIMPLES) & $1.028,54$ & $1.059,39$ & $1.091,18$ & $1.123,91$ & $1.157,63$ & $1.192,36$ & $1.228,13$ & $1.264,97$ & $1.302,92$ & $1.342,01$ & $1.382,27$ & $1.423,74$ \\
\hline Fluxo operacional líquido & $2.224,22$ & $2.042,85$ & $2.301,65$ & $2.568,20$ & $2.842,76$ & $3.125,55$ & $2.416,83$ & $3.716,84$ & $4.025,86$ & $4.344,14$ & $4.671,97$ & $2.566,00$ \\
\hline \multicolumn{13}{|c|}{ II - ATIVIDADES DE INVESTIMENTOS } \\
\hline \multicolumn{13}{|l|}{ Desembolsos para Investimentos } \\
\hline Obras, Móveis e Utensílios & $10.000,00$ & -1 & - & - & - & & - & - & 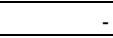 & 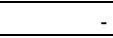 & & \\
\hline Fluxo de investimento líquido & $(10.000,00)$ & & -1 & & & & - & - & & & & \\
\hline \multicolumn{13}{|c|}{ II - ATIVIDADES DE FINANCIAMENTOS } \\
\hline \multicolumn{13}{|l|}{ Embolsos de Financiamentos } \\
\hline Empréstimos & - & -1 & -1 & & - & - & - & - & - & - & & \\
\hline \multicolumn{13}{|l|}{ Desembolsos de Financiamentos } \\
\hline Amortização de empréstimos & $2.000,00$ & $2.000,00$ & $2.000,00$ & $2.000,00$ & $2.000,00$ & $2.000,00$ & & & & & & \\
\hline Fluxo financiamentos líquido & $(2.000,00)$ & $(2.000,00)$ & $(2.000,00)$ & $(2.000,00)$ & $(2.000,00)$ & $(2.000,00)$ & & - & & - & & \\
\hline Caixa líquido por período & $(9.775,78)$ & \begin{tabular}{l|l|}
42,85 \\
\end{tabular} & 301,65 & 568,20 & 842,76 & $1.125,55$ & $2.416,83$ & $3.716,84$ & $4.025,86$ & $4.344,14$ & $4.671,97$ & $2.566,00$ \\
\hline Saldo inicial das disponibilidades & $10.154,11$ & 378,33 & 421,18 & 722,82 & $1.291,03$ & $2.133,79$ & $3.259,34$ & $5.676,16$ & $9.393,01$ & $13.418,86$ & $17.763,00$ & $22.434,98$ \\
\hline & & & & & & & & & & & & \\
\hline Saldo final das disponibilidades & 378,33 & 421,18 & 722,82 & $1.291,03$ & $2.133,79$ & $3.259,34$ & $5.676,16$ & $9.393,01$ & $13.418,86$ & $17.763,00$ & $22.434,98$ & $25.000,98$ \\
\hline
\end{tabular}




\begin{tabular}{|c|c|c|c|c|c|c|c|c|c|c|c|c|}
\hline \multicolumn{13}{|c|}{ Fluxo de Caixa 4응 } \\
\hline Valores em Reais (R\$) & Mês 1 & Mês 2 & Mês 3 & Mês 4 & Mês 5 & Mês 6 & Mês 7 & Mês 8 & Mês 9 & Mês 10 & Mês 11 & Mês 12 \\
\hline \multicolumn{13}{|c|}{ I- ATIVIDADES OPERACIONAIS } \\
\hline \multicolumn{13}{|l|}{ Embolsos Operacionais } \\
\hline Receita com vendas & $41.491,75$ & \begin{tabular}{|l|l|}
$42.321,58$ \\
\end{tabular} & $43.168,01$ & $44.031,37$ & \begin{tabular}{|l|}
$44.912,00$ \\
\end{tabular} & $45.810,24$ & $46.726,45$ & $47.660,97$ & $48.614,19$ & $49.586,48$ & $50.578,21$ & $51.589,77$ \\
\hline \multicolumn{13}{|l|}{ Desembolsos Operacionais } \\
\hline Custo do produto & $26.969,64$ & \begin{tabular}{|l|l}
$27.509,03$ \\
\end{tabular} & $28.059,21$ & $28.620,39$ & \begin{tabular}{|l|}
$29.192,80$ \\
\end{tabular} & $29.776,66$ & $30.372,19$ & $30.979,63$ & $31.599,23$ & $32.231,21$ & \begin{tabular}{l|l|}
$32.875,83$ \\
\end{tabular} & $33.533,35$ \\
\hline Aluguel da loja & $2.500,00$ & $2.500,00$ & $2.500,00$ & $2.500,00$ & $2.500,00$ & $2.500,00$ & $2.500,00$ & $2.500,00$ & $2.500,00$ & $2.500,00$ & $2.500,00$ & $2.500,00$ \\
\hline Água, energia elétrica & 120,00 & 120,00 & 120,00 & 120,00 & 120,00 & 120,00 & 120,00 & 120,00 & 120,00 & 120,00 & 120,00 & 120,00 \\
\hline Telefone, Internet & 120,00 & 120,00 & 120,00 & 120,00 & 120,00 & 120,00 & 120,00 & 120,00 & 120,00 & 120,00 & 120,00 & 120,00 \\
\hline Pessoal Salário/Encargos & $1.983,64$ & $1.983,64$ & $1.983,64$ & $1.983,64$ & $1.983,64$ & $1.983,64$ & $1.983,64$ & $1.983,64$ & $1.983,64$ & $1.983,64$ & $1.983,64$ & $3.967,28$ \\
\hline Comissão vendedores & $1.244,75$ & $1.269,65$ & $1.295,04$ & $1.320,94$ & $1.347,36$ & $1.374,31$ & $1.401,79$ & $1.429,83$ & $1.458,43$ & $1.487,59$ & $1.517,35$ & $1.547,69$ \\
\hline Pró-Labore & $2.000,00$ & $2.000,00$ & $2.000,00$ & $2.000,00$ & $2.000,00$ & $2.000,00$ & $2.000,00$ & $2.000,00$ & $2.000,00$ & $2.000,00$ & $2.000,00$ & $2.000,00$ \\
\hline Marketing & $1.000,00$ & & & & & & $1.000,00$ & & & & & \\
\hline Despesas com veiculo & 200,00 & 200,00 & 200,00 & 200,00 & 200,00 & 200,00 & 200,00 & 200,00 & 200,00 & 200,00 & 200,00 & 200,00 \\
\hline Taxas de Bancos & 50,00 & 50,00 & 50,00 & 50,00 & 50,00 & 50,00 & 50,00 & 50,00 & 50,00 & 50,00 & 50,00 & 50,00 \\
\hline Contador & 460,00 & 460,00 & 460,00 & 460,00 & 460,00 & 460,00 & 460,00 & 460,00 & 460,00 & 460,00 & 460,00 & 920,00 \\
\hline Material de escritório e diversos & 150,00 & 150,00 & 150,00 & 150,00 & 150,00 & 150,00 & 150,00 & 150,00 & 150,00 & 150,00 & 150,00 & 150,00 \\
\hline ICMS (Regime simplificado - SIMPLES) & $1.452,21$ & $1.481,26$ & $1.510,88$ & $1.541,10$ & $1.571,92$ & $1.603,36$ & $1.635,43$ & $1.668,13$ & $1.701,50$ & $1.735,53$ & $1.770,24$ & $1.805,64$ \\
\hline Fluxo operacional líquido & $3.241,51$ & $4.478,01$ & $4.719,24$ & $4.965,30$ & $5.216,28$ & $5.472,28$ & $4.733,40$ & $5.999,74$ & $6.271,41$ & $6.548,51$ & $6.831,15$ & $4.675,80$ \\
\hline \multicolumn{13}{|c|}{ II - ATIVIDADES DE INVESTIMENTOS } \\
\hline \multicolumn{13}{|l|}{ Desembolsos para Investimentos } \\
\hline Obras, Móveis e Utensílios & - & -1 & - & - & -1 & & - & - & - & - & & \\
\hline Fluxo de investimento líquido & & & - & & & & - & - & & - & & \\
\hline \multicolumn{13}{|c|}{ II - ATIVIDADES DE FINANCIAMENTOS } \\
\hline \multicolumn{13}{|l|}{ Embolsos de Financiamentos } \\
\hline Empréstimos & -1 & -1 & - & - & -1 & - & - & - & - & - & - & 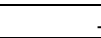 \\
\hline \multicolumn{13}{|l|}{ Desembolsos de Financiamentos } \\
\hline \multirow{2}{*}{\multicolumn{13}{|c|}{$\begin{array}{l}\text { Amortização de empréstimos } \\
\text { Fluxo financiamentos líquido }\end{array}$}} \\
\hline & & & & & & & & & & & & \\
\hline Caixa líquido por período & $3.241,51$ & $4.478,01$ & $4.719,24$ & $4.965,30$ & $5.216,28$ & $5.472,28$ & $4.733,40$ & $5.999,74$ & $6.271,41$ & $6.548,51$ & $6.831,15$ & $4.675,80$ \\
\hline Saldo inicial das disponibilidades & 2500098 & 28.242 .48 & 32720,50 & 37.439 .74 & 42.405 .04 & 47621.32 & $53.093,60$ & 57827.00 & 63826,73 & 70.098 .14 & 76.646 .65 & 83.477 .80 \\
\hline & & & & & & & & & & & & \\
\hline Saldo final das disponibilidades & $28.242,48$ & $32.720,50$ & $37.439,74$ & $42.405,04$ & $47.621,32$ & $53.093,60$ & $57.827,00$ & $63.826,73$ & $70.098,14$ & $76.646,65$ & $83.477,80$ & $88.153,60$ \\
\hline
\end{tabular}




\begin{tabular}{|c|c|c|c|c|c|c|c|c|c|c|c|c|}
\hline \multicolumn{13}{|c|}{ Fluxo de Caixa $5^{\circ}$ Ano } \\
\hline Valores em Reais (R\$) & Mês 1 & Mês 2 & Mês 3 & Mês 4 & Mês 5 & Mês 6 & Mês 7 & Mês 8 & Mês 9 & Mês 10 & Mês 11 & Mês 12 \\
\hline \multicolumn{13}{|c|}{ I - ATIVIDADES OPERACIONAIS } \\
\hline \multicolumn{13}{|l|}{ Embolsos Operacionais } \\
\hline Receita com vendas & $52.621,57$ & $53.674,00$ & $54.747,48$ & $55.842,43$ & $56.959,28$ & \begin{tabular}{l|l|}
$58.098,46$ \\
\end{tabular} & $59.260,43$ & $60.445,64$ & $61.654,55$ & $62.887,64$ & $64.145,40$ & $65.428,30$ \\
\hline \multicolumn{13}{|l|}{ Desembolsos Operacionais } \\
\hline Custo do produto & $34.204,02$ & $34.888,10$ & $35.585,86$ & $36.297,58$ & $37.023,53$ & $37.764,00$ & $38.519,28$ & $39.289,67$ & $40.075,46$ & $40.876,97$ & $41.694,51$ & $42.528,40$ \\
\hline Aluguel da loja & $2.500,00$ & $2.500,00$ & $2.500,00$ & $2.500,00$ & $2.500,00$ & $2.500,00$ & $2.500,00$ & $2.500,00$ & $2.500,00$ & $2.500,00$ & $2.500,00$ & $2.500,00$ \\
\hline Água, energia elétrica & 120,00 & 120,00 & 120,00 & 120,00 & 120,00 & 120,00 & 120,00 & 120,00 & 120,00 & 120,00 & 120,00 & 120,00 \\
\hline Telefone, Internet & 120,00 & 120,00 & 120,00 & 120,00 & 120,00 & 120,00 & 120,00 & 120,00 & 120,00 & 120,00 & 120,00 & 120,00 \\
\hline Pessoal Salário/Encargos & $1.983,64$ & $1.983,64$ & $1.983,64$ & $1.983,64$ & $1.983,64$ & $1.983,64$ & $1.983,64$ & $1.983,64$ & $1.983,64$ & $1.983,64$ & $1.983,64$ & $3.967,28$ \\
\hline Comissão vendedores & $1.578,65$ & $1.610,22$ & $1.642,42$ & $1.675,27$ & $1.708,78$ & $1.742,95$ & $1.777,81$ & $1.813,37$ & $1.849,64$ & $1.886,63$ & $1.924,36$ & $1.962,85$ \\
\hline Pró-Labore & $2.000,00$ & $2.000,00$ & $2.000,00$ & $2.000,00$ & $2.000,00$ & $2.000,00$ & $2.000,00$ & $2.000,00$ & $2.000,00$ & $2.000,00$ & $2.000,00$ & $2.000,00$ \\
\hline Marketing & $1.000,00$ & - & - & - & - & - & $1.000,00$ & - & & & & \\
\hline Despesas com veiculo & 200,00 & 200,00 & 200,00 & 200,00 & 200,00 & 200,00 & 200,00 & 200,00 & 200,00 & 200,00 & 200,00 & 200,00 \\
\hline Taxas de Bancos & 50,00 & 50,00 & 50,00 & 50,00 & 50,00 & 50,00 & 50,00 & 50,00 & 50,00 & 50,00 & 50,00 & 50,00 \\
\hline Contador & 460,00 & 460,00 & 460,00 & 460,00 & 460,00 & 460,00 & 460,00 & 460,00 & 460,00 & 460,00 & 460,00 & 920,00 \\
\hline Material de escritório e diversos & 150,00 & 150,00 & 150,00 & 150,00 & 150,00 & 150,00 & 150,00 & 150,00 & 150,00 & 150,00 & 150,00 & 150,00 \\
\hline ICMS (Regime simplificado - SIMPLES) & $1.841,75$ & $1.878,59$ & $1.916,16$ & $1.954,48$ & $1.993,57$ & $2.033,45$ & $2.074,12$ & $2.115,60$ & $2.157,91$ & $2.201,07$ & $2.245,09$ & $2.289,99$ \\
\hline Fluxo operacional líquido & $6.413,51$ & $7.713,45$ & $8.019,39$ & $8.331,45$ & $8.649,75$ & $8.974,42$ & $8.305,58$ & $9.643,37$ & $9.987,91$ & $10.339,34$ & $10.697,80$ & $8.619,79$ \\
\hline \multicolumn{13}{|c|}{ II - ATIVIDADES DE INVESTIMENTOS } \\
\hline \multicolumn{13}{|l|}{ Desembolsos para Investimentos } \\
\hline Obras, Móveis e Utensílios & & & - & - & - & - & - & - & & - & - & \\
\hline Fluxo de investimento líquido & & & - & & & & - & - & & & & \\
\hline \multicolumn{13}{|c|}{ II - ATIVIDADES DE FINANCIAMENTOS } \\
\hline \multirow{2}{*}{\multicolumn{13}{|c|}{$\begin{array}{l}\text { Embolsos de Financiamentos } \\
\text { Empréstimos }\end{array}$}} \\
\hline & & & & & & & & & & & & \\
\hline \multicolumn{13}{|l|}{ Desembolsos de Financiamentos } \\
\hline \multicolumn{13}{|l|}{ Amortização de empréstimos } \\
\hline \multicolumn{13}{|l|}{ Fluxo financiamentos líquido } \\
\hline Caixa líquido por período & $6.413,51$ & $7.713,45$ & $8.019,39$ & $8.331,45$ & $8.649,75$ & 8.974 .42 & $8.305,58$ & 9.643 .37 & $9.987,91$ & 10.339 .34 & $10.697,80$ & $8.619,79$ \\
\hline & & & & & & & & & & & & \\
\hline Saldo inicial das disponibilidades & $88.153,60$ & $94.567,11$ & $102.280,56$ & $110.299,95$ & $118.631,40$ & $127.281,15$ & $136.255,58$ & $144.561,16$ & $154.204,53$ & $164.192,43$ & $174.531,77$ & $185.229,57$ \\
\hline Saldo final das disponibilidades & $94.567,11$ & $102.280,56$ & $110.299,95$ & $118.631,40$ & $127.281,15$ & $136.255,58$ & $144.561,16$ & $154.204,53$ & $164.192,43$ & $174.531,77$ & $185.229,57$ & $193.849,36$ \\
\hline
\end{tabular}




\section{Indicadores}

O primeiro e principal indicador a ser analisado é o ponto de equilíbrio (break-even point) do empreendimento. Pelo valor do fluxo de caixa operacional líquido, verifica-se que o ponto de equilíbrio é atingido no oitavo mês do primeiro ano de operação, quando esse fluxo se torna positivo. Considerando que a empresa possui:

Custos fixos mensais $(C)=R \$ 5.091,82$

Custos Variáveis por cliente $(U)=R \$ 30,00 \times 0,65=R \$ 19,50$

Preço de Venda por cliente $(U)=R \$ 30,00$

O ponto de Equilíbrio $(Q)$ representa a quantidade $Q$ vendida mensalmente para que a empresa não tenha prejuízos. De forma que:

RECEITA DE VENDAS = Custo Fixo + Total do Custo Variável

$$
Q \times 30,00=5.091,82+(Q \times 19,50)
$$

$\mathrm{Q}=485$ clientes

A empresa precisa vender para 485 clientes, considerando um gasto médio de $\mathrm{R} \$ 30,00$ com um lucro de $35 \%$ sobre os produtos, para chegar ao ponto de equilíbrio.

O segundo e importante indicador é o prazo de retorno dos recursos aportados ao empreendimento (payback period), que será no primeiro mês do primeiro ano. Este ponto pode ser observado no primeiro momento em que o caixa líquido torna-se positivo após o início do pagamento do empréstimo.

\section{Análise de Viabilidade Financeira do Empreendimento}

Após o levantamento estimado da receita, custos da empresa, custo unitário por unidade, margem de venda e preço unitário de venda, è possível concluir que a taxa de crescimento das receitas é superior a das despesas e, com o início do pagamento do empréstimo, a empresa terá lucro a partir do primeiro mês do segundo ano. Atesta-se, assim, a viabilidade de implantação do empreendimento CANTINHO ÁRABE. 


\section{CONSIDERAÇÕES FINAIS}

Este trabalho teve como principal objetivo desenvolver um estudo para verificação da viabilidade de implantação de um empreendimento voltado ao turismo gastronômico para comercializar produtos árabes em Brasília a partir da elaboração de um plano de negócios, guiando-se pelos objetivos específicos de identificar a organização e os processos de um empreendimento que comercializa produtos árabes; analisar o mercado consumidor, fornecedores e concorrentes no contexto do turismo gastronômico; desenvolver o plano de negócios; e avaliar a viabilidade econômica de implantação de empreendimento proposto. O problema de pesquisa, também nessa mesma linha, questiona sobre a viabilidade de abertura de um empreendimento que fornece produtos árabes em Brasília.

A criação de um plano de negócios antecedendo a criação da empresa demonstra-se de grande importância para organizar idéias, traçar objetivos e criar estratégias. Os dados aqui analisados comprovam a relevância desse documento, já que, uma vez demonstrados os riscos, minimizam-se as incertezas, e, conseqüentemente, as possibilidades de insucesso da empresa, bem como ele permite antever as chances que o mercado oferece, maximizando, então, as possibilidades de perpetuação do empreendimento.

Os métodos e técnicas de pesquisa utilizada para alcançar o objetivo do trabalho foram: Pesquisa bibliográfica; pesquisa documental; pesquisa participante; pesquisa interativa; pesquisa de mercado; coleta de dados: aplicação de questionários a potenciais clientes para identificar condições de mercado relativas ao negócio proposto; análise e apresentação dos dados coletados a partir da aplicação dos questionários com potenciais clientes; elaboração de um plano de negócios considerando as informações obtidas no referencial teórico e na análise de dados para verificar a viabilidade de implantação de do empreendimento proposto.

A coleta foi realizada no período entre 27 de abril a 08 de maio de 2009, foram coletados dados na cidade de Brasília com cidadãos. Em relação aos dados coletados a partir dos questionários aplicados aos potenciais clientes, foram analisados estatisticamente e apresentados em gráficos com o intuito de identificar 
as necessidades, desejos e carências existentes no mercado e também foram analisados de forma qualitativa no que diz respeito ao conteúdo para elaboração do plano de negócios, sendo assim uma pesquisa qualitativa e quantitativa.

Ao aplicar os questionários com 50 potenciais clientes foi possível constatar que $70 \%$ dos entrevistados não sabiam da existência de um empreendimento que fornece produtos árabes, e os 30\% que já fizeram compra em um local que fornece esses produtos foram por indicação de algum conhecido.

Os fatores que influenciariam na escolha de um local para comprar produtos árabes seriam 50\% qualidade do produto, $27 \%$ preço e $9 \%$ qualidade no atendimento. Após a realização das entrevistas, foi possível perceber que os entrevistados gostam da idéia da abertura de um empreendimento que fornece produtos árabes, sendo que $63 \%$ acharam ótima a abertura e $32 \%$ bom. Constatase, assim, que os potenciais clientes gostam dos produtos árabes, em especial da comida, estão dispostos a comprar produtos árabes, mas nem sempre sabem da existência de um local onde possam encontrar o mesmo. Tornando assim viável a abertura de um empreendimento neste segmento.

A partir da análise das etapas do Plano de Negócios, verificou-se que no plano foi definida a identidade da empresa, estabelecendo-se os objetivos, as metas os valores, formulando-se as estratégias, organizando-se os produtos serviços.

No plano de marketing foi analisado o mercado e o ambiente, constatando as oportunidades, ameaças, pontos fracos e pontos fortes, bem como identificando os concorrentes.

No plano operacional foi desenvolvida a estrutura física e organizacional da empresa, definindo-se o número de funcionários e cargos.

$\mathrm{Na}$ análise financeira, foram levados em consideração alguns pressupostos, primeiro, que a empresa atenderá 390 clientes por mês, visto que em Brasília (Asa Sul, Asa Norte, Lago Sul e Lago Norte), estima-se ter em torno de 200.000 habitantes, com isso a meta da empresa é fazer com que se tornem clientes potenciais $0,2 \%$ dessa população, levando em consideração que cada cliente gastaria em média por dia $\mathrm{R} \$ 30,00$ na empresa. Considerando as estimativas de 
número de clientes e de valor médio gasto por cliente, a empresa terá uma receita bruta de $\mathrm{R} \$ 11.700,00$ no primeiro mês. Este valor será reajustado com o passar do tempo, considerando uma receita crescente de $5 \%$ no primeiro ano, de $3 \%$ no segundo e terceiro ano e $2 \%$ no quarto e quinto ano.

O investimento inicial será de $R$ \$22.950,00 além do desembolso operacional de $R \$ 13.164,82$ para primeiro mês. Dessa forma, foi estipulado um empréstimo de $R \$ 35.000,00$ para minimizar o risco pela falta de receita. A partir do oitavo mês, a empresa encontrará o ponto de equilíbrio, contudo, só terá lucro a partir do primeiro mês do segundo ano, devido o início do pagamento do empréstimo a partir do sexto mês.

Conclui-se que os resultados obtidos através dos estudos, análises, projeções e estimativas do comércio varejista apontam a viabilidade da empresa CANTINHO ÁRABE. 


\section{REFERÊNCIAS}

ANDRADE, Renato Brenol. Manual de Eventos. $2^{\circ}$ edição. Caxias do Sul: EDUCS, 2002.

BALLOU, Ronald H. Logística Empresarial: transportes, administração de materiais e distribuição física. São Paulo, Atlas, 1993.

BARBOSA, Ycarim Melgaço. O despertar do turismo: um olhar crítico sobre os não-lugares. São Paulo: Aleph, 2001.

BARRETO, Margarita. Turismo e legado cultural: as possibilidades do planejamento. Papirus. Campinas, SP. 2000. (Coleção Turismo).

BENI, José Vicente. Turismo fundamentos e dimensões. São Paulo: Ática, 2002.

BRAGA, Roberto. Fundamento e técnicas de administração financeira. São Paulo: Atlas, 1989.

BRIGHAM, Eugene F. e GAPENSKI et AL, Louis C. Administração Financeira: teoria e prática. São Paulo: Atlas, 2001.

BRITO, Breno Xavier de e CARDOSO, Alberto Lemos. Administração financeira e orçamentária. Goiânia: Editora UCG, 2002.

COBRA, Marcos Henrique Nogueira. Marketing básico: uma perspectiva brasileira. $4^{\circ}$ edição. São Paulo. Atlas, 1997.

COOPER, Chris e FLETCHER John. et al Turismo, princípios e prática, 2 ed.Porto Alegre: Bookman, 2001.

DENCKER, Ada de Freitas Maneti. Métodos e técnicas de pesquisa em turismo. São Paulo: Futura, 2003.

DOLABELA, Fernando. O segredo de Luísa. 30 edição. São Paulo: Cultura, 2006.

DORNELAS, José. Plano de negócios. São Paulo, 2005. Disponível em: $<$ http://www.planodenegócios.com.br/dinamica artigo.asp?tipotabela=artigo\&id=23 >, acesso em: 14/04/09 ás 15h13min.

FELIPINI, Dailton. Plano de negócios. São Paulo, 2005. Disponível em: $<$ http://www.e-commerce.org.br/plano de negocio.htm> - acesso em: 14/04/09 ás $16 \mathrm{~h} 49 \mathrm{~min}$.

FUNARI, Pedro Paulo e PINSKY, Jaime. (org.). Turismo e patrimônio cultural. São Paulo: Contexto, 2003. (Coleção Turismo Contexto), 
IGNARRA, Luiz Renato. Fundamentos do Turismo. São Paulo: Pioneira, 2002.

KOTLER, Philip. Administração de marketing: a edição do novo milênio. Editora Prentice Hall: São Paulo, 2000.

KWASNICKA, Lacava Eunice. Teoria Geral da Administração. 2ำ Edição, São Paulo: ATLAS S.A, 1989.

LAGE, Beatriz Helena e MILONE, Paulo César (Organizadores). Turismo: teoria e prática. São Paulo: Atlas, 2000.

LOPES, Adriana. Turismo: Alimentação e cultura. Brasília 2009. Disponível em http://www.cet.unb.br/index. php?option=com_content\&task=view\&id=826\&ltemid=14 acesso em: 19/06/2009 às 13 h00min.

MARION, José Carlos. Contabilidade básica. $6^{\circ}$ edição. São Paulo. Atlas, 1998.

MAXIMIANO, Antônio César Amaru, Introdução à administração. $3^{\circ}$ edição. São Paulo: Atlas, 2000.

MAXIMIANO, Antônio César Amaru, Introdução à administração. $5^{\circ}$ edição. São Paulo: Atlas, 2000.

MEGGINSON, Leon C. e MOSLEY, Donald C. et al. Administração conceitos e aplicações. $4^{\circ}$ edição. São Paulo: Harbra, 1998.

MELGAR, Ernesto Guilenea. Fundamentos de planejamento e marketing em turismo. São Paulo: Contexto, 2001. (Coleção Turismo Contexto).

MELO NETO, Francisco Paulo de. Marketing de Eventos. 2 edição. SPRINT. Rio de Janeiro. 1999.

NEVES, Silvério e VICECONTI, Eduardo E. V. Contabilidade básica. $6^{\circ}$ edição. São Paulo, Frase Editora, 1997.

NUNES, Paulo. Administração de Recursos Humanos. http://www.knoow.net/cienceconempr/gestao/gestaorecursoshumanos. htm\#vermais. acessado em: 12/08/2009 às 10; 44.

PEREIRA, Heitor Jose. Criando seu próprio negócio: Como desenvolver o potencial empreendedor. Brasília: SEBRAE, 1995.

POZO, Hamilton. Administração de recursos materiais e patrimoniais: uma abordagem logística. 3ํeição. São Paulo: Atlas, 2004.

ROSA, Claudio Afrânio. Como elaborar um plano de negócio. Brasília: SEBRAE, 2007.

SALIM, César et al. Construindo planos de negócios. Rio de Janeiro: Elsevier, 2005. 
SCATAMACCHIA, Maria Cristina M. Turismo e Arqueologia. Aleph. São Paulo. 2005. (Coleção $A B C$ do turismo).

SCHLUTER, Regina G. Gastronomia e Turismo. São Paulo: Aleph, 2003. (Coleção $A B C$ do Turismo).

SEBRAE. A Competitividade em setores de comércio, de serviços e do turismo no Brasil. Perspectivas até 2015. Natal, 2008. Relatório Executivo. Confederação Nacional do Comércio de Bens, Serviços e Turismo. Disponível em $<$ http://www.biblioteca.sebrae.com.br/bds/BDS.nsf/8B289FC81286CB48832574E900 631B12/\$File/NT0003A272.pdf> acesso em: 01/04/2009 às 15h00min.

SLACK, Nigel e CHAMBERS, Stuart. Administração da Produção. $2^{\circ}$ edição. São Paulo. Atlas, 2002.

STONER, James A. F e FREEMAN, R. Edward. Administração. $5^{\circ}$ edição. Rio de Janeiro: LTC, 1999.

TRIGO, Luiz Gonzaga Godoi. Turismo Básico. -Série Apontamento - São Paulo: Editora SENAC São Paulo, 1995.

TV TURISMO. http://tvturismo.terra.com.br/brasilia/brasilia.htm,acesso em: 12/06/09 ás 16 h00min. 


\section{APÊNDICES}

\section{Apêndice A: Questionário aplicado aos potenciais clientes.}

Eu, Daiany Georges de Paula Ottoni, aluna do curso de Gestão de Negócios em Turismo, peço gentilmente a sua colaboração para o desenvolvimento do trabalho de conclusão de curso.

1. Sexo:
( )Feminino
( ) Masculino

2. Estado Civil:
( ) Solteiro (a)
( ) Casado (a)
( ) Viúvo (a)
( ) Outros

3. Grau de escolaridade:
( ) $1^{\circ}$ grau incompleto
( ) $1^{\circ}$ grau com pleto
( ) $2^{\circ}$ grau incompleto
$2^{\circ}$ grau completo
( ) Superior incompl eto
( ) Superior completo
( ) Pós- Graduação

4. Já fez compras em algum empório árabe na cidade de Brasília?

( ) $\operatorname{Sim}$ ( ) Não

Se sim, onde?

5. Como ficou sabendo da existência de um empório árabe?

( ) jornais e revista

( ) outdoors

( ) panfletos e folders

( ) televisão

( ) indicação (boca-a-boca)

( ) outros. Quais?

6. Tendo a preferência por um empório, estaria disposto a conhecer outros?

( ) $\operatorname{Sim}$

( ) Não

Por quê? 
7. Como você classificaria os serviços prestados e produtos oferecidos pelos empórios que já freqüentou?
( ) Ótimo
( )Bom
( ) Regular
( ) Ruim
( ) Péssimo

8. Há algum produto específico que o senhor(a) tem dificuldades para adquirir em Brasília?

9. Quais os fatores que influenciariam na escolha de um empório árabe para fazer suas compras?
( ) Qualidade do produto
( ) Qualidade no atendimento
( ) Preço
( ) Outras. Quais?

10. O que você acha da abertura de um novo empório na cidade de Brasília?
( ) Ótimo
( )Bom
( ) Regular
( ) Ruim
( ) Péssimo

11. Que tipo de produto árabe atrai mais sua atenção?
( ) comida
( ) roupas e acessórios
( ) fumo
( ) Bebidas

( ) outros. Quais? 


\section{Apêndice B: Roteiro de Entrevista aplicado ao dono de um empório árabe.}

1) Como a empresa é estruturada

Áreas

Pessoas Responsáveis

2) Caracterização da empresa (ano de fundação, missão, visão).

3) A estrutura física da empresa é alugada?

4) A empresa conta com quantos funcionários fixos e temporários?

5) Sua empresa trabalha com parceiros? Quem são seus parceiros? Que critérios utiliza para a escolha destes?

6) Como o senhor vê a clientela de Brasília, você acredita que eles estão dispostos a comprar?

7) Quais os pontos fortes e fracos?

8) Quais as ameaças e oportunidades?

9) Quais os fornecedores?

10) Como você vê a concorrência na cidade de Brasília? E como você classifica os serviços prestados pelos empórios em geral? 